\title{
ANÁLISE DA RESPOSTA ANTIOXIDATIVA DE CÉLULAS DE Nicotiana tabacum cv BY-2 SUBMETIDAS AO CÁDMIO
}

\section{PRISCILA LUPINO GRATÃO}

Dissertação apresentada à Escola Superior de Agricultura "Luiz de Queiroz", Universidade de São Paulo, para obtenção do título de Mestre em Agronomia. Área de concentração: Genética e Melhoramento de Plantas.

PIRACICABA

Estado de São Paulo - Brasil

Novembro- 2003 


\title{
ANÁLISE DA RESPOSTA ANTIOXIDATIVA DE CÉLULAS DE Nicotiana tabacum cv BY-2 SUBMETIDAS AO CÁDMIO
}

\section{PRISCILA LUPINO GRATÃO}

\author{
Bióloga
}

Orientador: Prof. Dr. RICARDO ANTUNES DE AZEVEDO

Dissertação apresentada à Escola Superior de Agricultura "Luiz de Queiroz", Universidade de São Paulo, para obtenção do título de Mestre em Agronomia. Área de concentração: Genética e Melhoramento de Plantas.

PIRACICABA

Estado de São Paulo - Brasil

Novembro - 2003 


\section{Dados Internacionais de Catalogação na Publicação (CIP) DIVISÃO DE BIBLIOTECA E DOCUMENTAÇÃO - ESALQ/USP}

Gratão, Priscila Lupino

Aná lise da resposta antioxidativa de células de Nic otiana ta ba cum c V BY-2 submetidasao cádmio / Prisc ila Lupino Gratão. - - Piracicaba, 2003.

109 p. : il.

Dissertação (mestra do) - - Escola Superior de Agricultura Luiz de Queiroz, 2003. Bibliogra fia.

1. Bioquímica vegetal2. Cádmio 3. Enzimas 4. Fumo 5. Poluição ambiental I. Titulo

CDD 633.71

"Permitida a cópia total ou parcial deste documento, desde que citada a fonte - $\mathrm{O}$ autor" 


\section{OFEREÇO,}

A Deus pela luz e proteção e aos meus pais pelo

apoio irrestrito, amor e compreensão dedicados

A memória de minha avó, que

sempre esteve ao meu lado

DEDICO 


\section{AGRADECIMENTOS}

À Deus por ter permitido o alcance de mais esse ideal;

Ao Prof. Ricardo Antunes de Azevedo, pela orientação, incentivo, oportunidade e acima de tudo a pessoa amiga;

Ao Prof. Victor A. Vitorello pelo apoio, colaboração e enriquecedoras discussões generosamente concedidas;

A amiga Flávia, sem a qual a realização deste trabalho não seria possível;

Ao amigo Rico pelo inestimável apoio a realização deste trabalho;

A amiga Dra.Salete pelo apoio, amizade e incentivo indispensáveis;

Aos amigos do Laboratório Genética Bioquímica de Plantas, Renato, Vanderlei, Fabrício, Patrícia, Alejandro, Rui, Georgia, Carmezini, Ariane e Bertha pela sempre amigável convivência;

Aos companheiros do Laboratório de Biologia Celular e Molecular do CENA, Cileide, Clovis, Vanderlei e Daniele por compartilharem conhecimentos e espaço de trabalho; 
A todos os professores e funcionários deste programa, em especial ao funcionário Berdan;

Aos meus amigos do Curso de Pós Graduação que fiz ao longo destes dois anos;

À Esalq/USP por todo apoio ao trabalho;

Ao CNPq pela concessão da bolsa de estudo;

Deixo o agradecimento especial a minha maior força incentivadora...

...... a você mãe!!! 


\section{SUMÁRIO}

Página

LISTA DE FIGURAS..................................................................... ix

LISTA DE ABREVIATURAS............................................................. xii

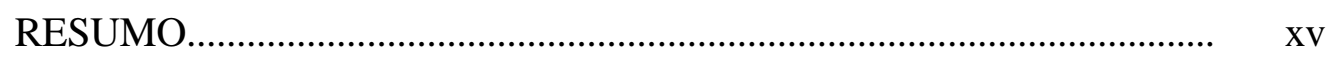

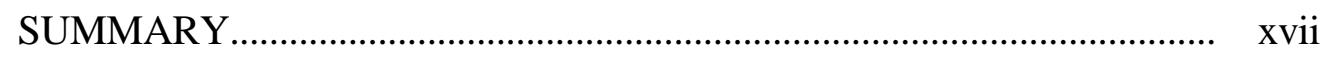

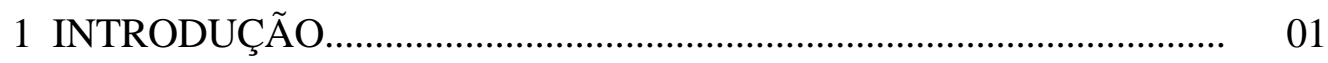

2 REVISÃO DA LITERATURA.......................................................... 02

2.1 Poluentes ambientais....................................................................... 02

2.2 Metais pesados em plantas............................................................... 03

2.3 Mecanismos de defesa e compostos produzidos por plantas em resposta à

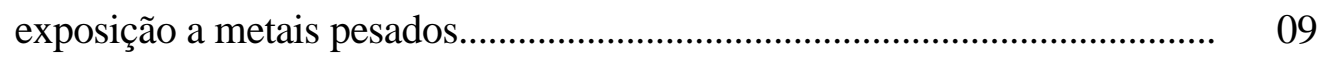

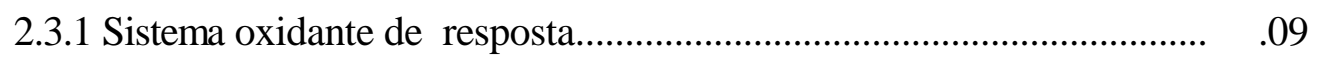

2.3.1.1. Superóxido dismutase .................................................................. 11

2.3.1.2. Catalase ...................................................................... 14

2.3.1.3. Glutationa Redutase .............................................................. 16

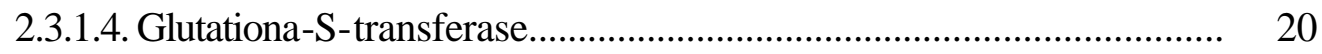

2.3.1.5. Guaiacol peroxidase ....................................................................... 21

2.4. Nicotiana tabacum cv BY-2 …................................................................. 22

3. MATERIAL E MÉTODOS................................................................. 25

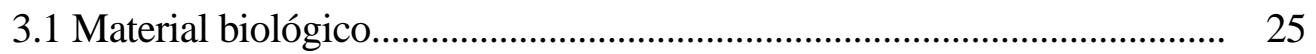

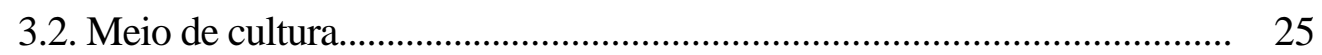


3.2.1. Meio completo líquido................................................................ 25

3.2.2. Soluções............................................................................... 26

3.3. Cultivo de células............................................................................... 27

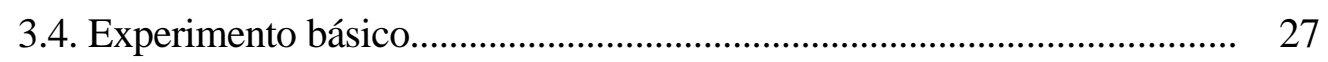

3.5. Extração e quantificação de aminoácidos.................................................. 28

3.6. Análise de aminoácidos solúveis por HPLC.......................................... 28

3.7. Cromatografia em camada delgada para aminoácidos.............................. 29

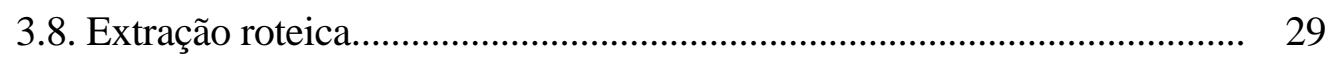

3.9. Determinação de proteínas.................................................................... 30

3.10. Atividade de enzimas antioxidantes.................................................. 30

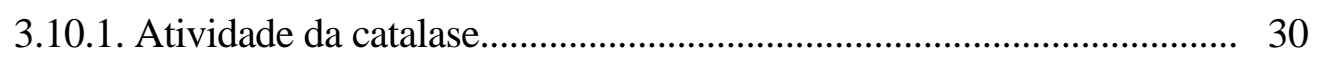

3.10.1.1. Atividade em espectrofotômetro.................................................. 30

3.10.1.2. Atividade em PAGE não desnaturante............................................. 31

3.10.2. Atividade da superóxido dismutase................................................ 32

3.10.2.1. Atividade em PAGE não desnaturante............................................. 32

3.10.3. Atividade de glutationa redutase.................................................... 33

3.10.3.1. Atividade em espectrofotômetro.................................................. 33

3.10.3.2. Atividade em PAGE não desnaturante.............................................. 33

3.10.4. Atividade da glutationa-S-transferase ................................................ 34

3.10.4.1. Atividade em espectrofotômetro....................................................... 34

3.10.5. Atividade da guaiacol peroxidase .................................................... 34

3.10.5.1. Atividade em espectrofotômetro.................................................... 34 
3.11. Peroxidação de lipídeos.................................................................... 35

3.12. Delineamento experimental............................................................... 36

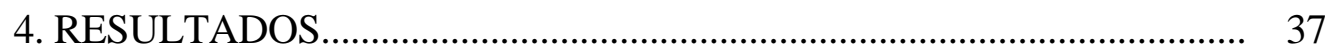

4.1. Crescimento e desenvolvimento.............................................................. 37

4.2. Cromatografia líquida de alto desempenho (HPLC) e cromatografia em

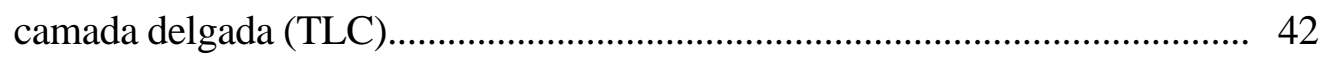

4.3. Atividade da catalase em espectrofotômetro e em PAGE não-

desnaturante.

46

4.4. Atividadse da superóxido dismutase em PAGE não desnaturante.

4.5. Atividadade da glutationa redutase em espectrofotômetro e em PAGE não

desnaturante.

4.6. Atividade de glutationa-S-transferase em espectrofotômetro.

4.7. Atividade de guaiacol peroxidase em espectrofotômetro. 58

4.8. Peroxidação lipídica.. 60

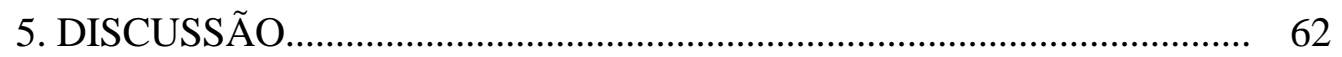

6. CONCLUSÕES.......................................................................... 74

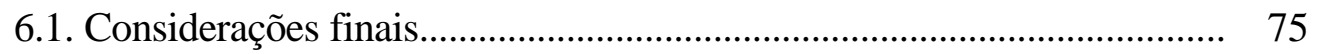

7. REFERÊNCIAS BIBLIOGRÁFICAS...................................................... 76 


\section{LISTA DE FIGURAS}

Página

1. Formação de $\mathrm{H} 2 \mathrm{O} 2$ a partir de radicais superóxidos em reação catalisada pela SOD.

2. Degradação do peróxido de hidrogênio catalisada pela CAT.

3. Formação de GSH a partir de GSSG em reação catalisada pela GR

4. Volume de células compactadas de BY-2 submetidas a concentrações de $\mathrm{CdCh}$ durante 96 horas.

5. Efeito do metal no crescimento celular nas concentrações (1) $0 \mathrm{mM}$, (2) $0,1 \mathrm{mM}$, (3) $0,2 \mathrm{mM}$ e (4) 0,5 $\mathrm{mM}$ de $\mathrm{CdCl}_{2}$.

6. Viabilidade celular de células de BY-2 submetidas ao cádmio

7. Efeito do metal na viabilidade celular após $48 \mathrm{~h}$ de exposição nas concentrações

(1) $0 \mathrm{mM}$, (2) 0,1 mM, (3) 0,2 mM e (4) 0,5 mM de $\mathrm{CdCl}$

8. Cromatografia de camada delgada para aminoácidos solúveis; (A) $0 \mathrm{mM}$,

(B) 0,1 mM e (C) 0,2 mM de $\mathrm{CdCl}_{2}$; (a) $0 \mathrm{~h}$, (b) 3h, (c) $6 \mathrm{~h}$, (d) $12 \mathrm{~h}$, (e) $24 \mathrm{~h}$, (f)

36 h, (g) 48 h, (h) 72 h e (i) 96 h; (1), (2), (3), e (4) padões de aminoácidos.. 
9. Aminoácidos solúveis totais de células BY -2, submetidas a diferentes

concentrações de $\mathrm{CdCl}$.

10. Atividade específica de CAT ( $\mu \mathrm{mol} / \mathrm{min} / \mathrm{mg}$ prot) em células de BY -2

submetidas à diferentes concentrações de $\mathrm{CdCl}_{2}$

11. Atividade de CAT em PAGE não desnaturante de células BY -2 submetidas a tratamentos com $0 \mathrm{mM}$ de $\mathrm{CdCl}$, por (1) $0 \mathrm{~h}$, (2) $3 \mathrm{~h}$, (3) $6 \mathrm{~h}$, (4) $12 \mathrm{~h}$. (5) $24 \mathrm{~h}$, (6) 36 h, (7) 48 h e (8) 72h; (a) padrão de CAT bovina. 47

12. Atividade de SOD determinada em PAGE não desnaturante de células BY -2 submetidas aos tratamentos com (A) $0 \mathrm{mM}$, (B) $0,1 \mathrm{mM}$ e (C) $0,2 \mathrm{mM}$ de $\mathrm{CdCb}$; (1) 0 h. (2) 3h, (3), 6 h, (4) 12h, (5) 24 h, (6) 36 h, (7) 48 h, (8) 72 h e (9) 96 h; (a) padrão de SOD de fígado bovino. As setas representam as isoformas de SOD...

13. Atividade específica de GR ( $\mu \mathrm{mo} 1 / \mathrm{min} / \mathrm{mg}$ prot) em células de BY -2 submetidas à diferentes concentrações de $\mathrm{CdCl}_{2}$ 52

14. Atividade de GR determinada em PAGE não denaturante em células de BY -2 sumetidas à (A) $0 \mathrm{mM}$, (B) $0.1 \mathrm{mM} \mathrm{e} \mathrm{(C)} 2,0 \mathrm{mM}$ de $\mathrm{CdCl}_{2}$; (1) 0 h, (2) $3 \mathrm{~h}$, (3) 6 h, (4) 12 h, (5) 24 h, (6) 36 h, (7) 48 h, (8) 72 h e (9) 96 h; (a) padrão de GR. 53

15. Atividade específica de GST ( $\mu \mathrm{mol} / \mathrm{min} / \mathrm{mg}$ prot) em células de BY -2 submetidas à diferentes concentrações de $\mathrm{CdCl}_{2}$ 56

16. Atividade específica de peroxidases ( $\mu \mathrm{mol} / \mathrm{min} / \mathrm{mg}$ prot) em células de BY -2 submetidas à diferentes concentrações de $\mathrm{CdCl}_{2}$. 
17. Quantidade de MDA (mmol/g tecido) em células de BY-2 submetidas ao

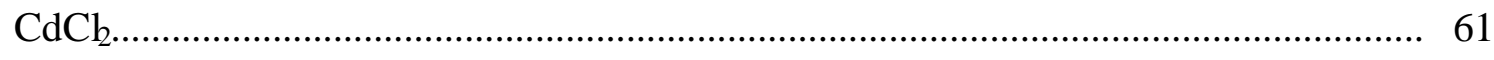




\section{LISTA DE SIGLAS, ABREVIATURAS ESIMBOLOS}

2,4 -D = ácido diclorofenoxiacético

y-Glu-Cys = gama-glutamilcisteína

$\beta$-Ala $=$ beta alanina

${ }^{1} \mathrm{O} 2$ = oxigênio "singlet"

a.a. = aminoácido

$\mathrm{AA}=$ ascorbato

$\mathrm{ABA}=$ ácido abcísico

$\mathrm{APX}=$ ascorbato peroxidase

$\mathrm{BSA}=$ soro albumina bovina

$\mathrm{BSO}=$ butionina sulfoximina

$c a d l=$ loco mutante para fitoquelatina

$\operatorname{cad} 2=$ loco mutante para fitoquelatina

$\mathrm{CAT}=$ catalase

Catl $=$ gene codificante da isoforma de catalase 1

Cat 2 = gene codificante da isoforma de catalase 2

Cat 3 = gene codificante da isoforma de catalase 3

$\mathrm{Cd}=$ cádmio

$\mathrm{CdCl}_{2}=$ cloreto de cádrnio

CDNA $=$ DNA complementar

$\mathrm{CdSO}_{4}=$ sulfato de cádmio

$\mathrm{Cr}=$ crômio

$\mathrm{Cu} / \mathrm{Zn}-\mathrm{SOD}=$ cobre/zinco superóxido dismutase 
d.d. $=$ deionizada

DHA $=$ desidroascorbato

$\mathrm{DHAR}=$ desidroascorbato redutase

DPIP $=$ dicloroindolacético

DTNB = 5,5" - ditiobis (2-ácido nitrobenzóico )

DTT $=$ ditiotreitol

EAOs $=$ espécies ativas de oxigênio

EDTA = ácido etileno diamino tetracético

$\mathrm{FAD}=$ flavina adenina dinucleotídeo

$\mathrm{FADH}=$ flavina adenina dinucleotídeo reduzida

$\mathrm{Fe}=$ ferro

$\mathrm{FeCl}_{3}=$ cloreto férrico

$\mathrm{Fe}-\mathrm{SOD}=$ ferro superóxido dismutase

Gly = glicina

GPX = guaiacol peroxidase

$\mathrm{GR}=$ glutationa redutase

$\mathrm{GSH}=$ glutationa reduzida

GSH2 = gene codificante da GSH

GSSG = glutationa oxidada

GST = glutationa-S-transferase

$\mathrm{H}_{2} \mathrm{O}=$ água

$\mathrm{H}_{2} \mathrm{O}_{2}=$ peróxido de hidrogênio

$\mathrm{Hg}=$ mercúrio

HMBPs = proteínas ligadas àmetais

$\mathrm{K}_{3} \mathrm{Fe}(\mathrm{CN} 6)$ = ferricianeto de potássio

MDA = malonaldeído

MDHAR $=$ monodesidroascorbato redutase

$\mathrm{Mn}=$ manganês

Mn-SOD = manganês superóxido dismutase

mRNA $=$ RNA mensageiro 
MS =meio de culturaMurashigue \& Skoog, (1962)

MT = proteína metalotioneína

MTf $=$ dimetiltiazol

$\mathrm{NaCl}=$ cloreto de sódio

$\mathrm{NADPH}=$ nicotinamida adenina dinucleotídeo fosfato reduzida

$\mathrm{NBT}=$ nitro blue tetrazolium

$\mathrm{Ni}=$ níquel

$\mathrm{O}_{2}=$ oxigênio molecular

$\mathrm{O}_{2}^{-}=$radica1 superóxido

$\mathrm{OH}^{-}=$radica1 hidroxila

$\mathrm{PA}=$ persulfato de amônia

PAGE $=$ eletroforese em gel de poliacrilamida

$\mathrm{Pb}=$ chumbo

PCs $=$ fitoquelatinas

POX = peroxidase

$(\mathrm{p} / \mathrm{v})=$ proporção peso/volume

PVPP = polivinil polipirrolidona

Ser $=$ serina

$\mathrm{SH}=$ grupo sulfidril

$\mathrm{SO}_{2}=$ dióxido de enxofre

SOD = superóxido dismutase

TEMED = N, N, N', N', - tetrametilenodiamina

TRIS $=$ Tris (hidroximetil)-Aminometano

$\mathrm{Zn}=$ zinco 


\title{
ANÁLISE DA RESPOSTA ANTIOXIDATIVA DE CÉLULAS DE Nicotiana tabacum cv BY-2 SUBMETIDAS AO CÁDMIO
}

\author{
Autor: PRISCILA LUPINO GRATÃO
}

Orientador: Prof. Dr. RICARDO ANTUNES DE AZEVEDO

\section{RESUMO}

A poluição por metais pesados, particularmente pelo cádmio, considerado um dos mais tóxicos é gerada principalmente pelas atividades de mineração e industriais, utilização de lodo de esgoto e fertilizantes fosfatados. Estes últimos contém o $\mathrm{Cd}$ em sua composição e sua utilização na agricultura tem aumentado a concentração desse metal no solo, reservas hídricas e plantas, o que pode aumentar a bioacumulação via cadeia alimentar. Identificou-se um grupo de peptídeos denominados fitoquelatinas (PCs), capazes de se ligar aos íons de metais pesados, incluindo o $\mathrm{Cd}$ e assim desintoxicando as células pela diminuição dos íons livres no citoplasma. Entretanto, danos oxidativos frequentemente ocorrem quando há exposição aos metais pesados, devido a intensificação na produção de espécies ativas de oxigênio. Também uma classe de 
enzimas antioxidantes tem sido relatada no combate às EAOs decorrentes do estresse oxidativo. Plantas expostas aos metais pesados apresentam alterações nas atividades dessas enzimas. Portanto, o estudo dessas alterações pode fornecer dados importantes relativos aos níveis de tolerância, especificidade da resposta em diferentes espécies e níveis de poluição no ambiente. Esses dados podem ser úteis em programas de melhoramento para obtenção de plantas mais tolerantes, além de estudos relacionados a bioacumulação e fitorremediação, uma vez que plantas tolerantes podem ajudar a diminuir a quantidade de metais nos solos contaminados. Neste trabalho, foi observado alterações nas atividades de CAT e peroxidases em células de BY-2 e um aumento expressivo na atividade de GR. A SOD apresentou alterações em isoformas específicas.

Os resultados sugerem que o mecanismo principal de defesa ao estresse por $\mathrm{Cd}$ em células BY-2 foi variável durante o tempo de exposição ao metal. Possivelmente a síntese de GSH tanto como substrato para fitoquelatinas quanto para GST foi significativa durante a fase inicial de estresse, sendo que a atividade de CAT e peroxidases são importantes durante o período final, onde provavelmente o estresse tornou-se mais severo. 


\title{
ANTIOXIDANT RESPONSE OF BY-2 Nicotiana tabacum CELLS TO CADMIUM STRESS
}

\author{
Author: PRISCILA LUPINO GRATÃO
}

Adviser: Prof. Dr. RICARDO ANTUNES DE AZEVEDO

\section{SUMMARY}

The contamination of environments by heavy metal pollution, mainly by cádmium $(\mathrm{Cd})$, considered one of the more toxic, is generated by mining and industrial activities, and sewage sludge and phosphated fertilizers used in agriculture. The latter contains $\mathrm{Cd}$ in its composition and with continuous agricultural utilization an increase in the heavy metals levels in soils, plants and water sources, have been observed which may contribute to the bioaccumulation and biomagnification in the food chain. A group of peptides termed phytochelatins (PCs) has been identified and are capable of binding heavy metal ions, including $\mathrm{Cd}$ and detoxifying the cells by the reduction of free ions in the cytosol. However, oxidative damage often occurs due to the generation of oxygen reactive species induced by heavy metals. A class of antioxidant enzymes has been reported for the scavenging of the oxygen reactive species. Plants exposed to heavy metals may exhibit alteration in enzyme activity. The study of such a response may allow the evaluation levels of tolerance, specificity the response of distinct plant species to levels of pollution in the environment. These data may be useful in breeding programs to select tolerant plants. Moreover, tolerant plants may be used in 
phytorremediation, by reducing the amount of heavy metals in contaminated soils. In this study, it was observed alterations in CAT and peroxidases activities in BY-2 cells and an extensive increase in GR activity. SOD activity was altered in the isoforms analysed. The results suggest that in BY-2 cells the main defence system to $\mathrm{Cd}$ stress is variable during the heavy metal exposure time. The synthesis of GSH, which is used in the synthesis of phytochelatins and substrate for GST is evident during the onset of the stress with CAT and peroxidases taking over the antioxidative responses once the stress becomes severe. 


\section{INTRODUÇÃO}

Os metais pesados representam o maior resíduo industrial contaminante de solos, plantas e animais no ecossistema, com intensos efeitos tóxicos ao homem associados à sua ampla distribuição no ambiente. Dessa forma, o estudo da toxicidade de metais pesados em plantas vem atraindo a atenção de muitos cientistas ambientalistas.

As plantas desenvolveram alguns mecanismos para reduzir a concentração de metais pesados livres no citosol das células os quais incluem a formação de peptídeos ricos em cisteínas, conhecidos como fitoquelatinas e metalotioneínas. Além destes peptídeos, outro mecanismo de defesa desenvolvido pelas plantas para a tolerância a exposição aos metais pesados é a produção de um sistema de defesa, que inclui um sistema de enzimas antioxidantes capazes de remover, neutralizar ou limpar radicais livres.

Assim, estudo da atividade enzimática serve como um critério de avaliação da fitotoxicidade de metais pesados em plantas. Uma vez sabendo-se a via preferencial de desintoxicação destes metais em plantas pode-se eventualmente traçar estratégias de estudo e melhoramento genético, como por exemplo a manipulação de enzimas que possam condicionar tanto sensibilidade como tolerância a metais em diferentes cultivares. Pesquisas em melhoramento vegetal buscam o entendimento destes mecanismos, principalmente de caracteres correlacionados com a formação de fitoquelatinas. Assim, a partir deste conhecimento os programas de fitorremediação podem ser utilizados para desintoxicação de ambientes tornando-os propícios para o desenvolvimento de uma Agricultura mais segura. 


\section{REVISÃO DA LITERATURA}

\subsection{Poluentes ambientais}

Atualmente existe uma grande preocupação com relação aos efeitos a curto e longo prazo que muitos poluentes químicos possam ter sobre a saúde pública e o meio ambiente, pois a crescente industrialização das últimas décadas tem exposto animais e vegetais a muitos elementos químicos potencialmente tóxicos. Entre estes, os metais pesados representam o maior contaminante industrial de solos, corpos de água, plantas e animais no ecossistema (Ghoshroy et al., 1998) de tal forma que o estudo da toxicidade de metais pesados em plantas e microrganismos vem atraindo a atenção de muitos ambientalistas (Prasad, 1995).

A importância de se estudar estes metais deve-se aos seus intensos efeitos tóxicos ao homem e outros seres vivos, associados à sua ampla liberação no ambiente. Com o aumento nas atividades industriais, a poluição do ambiente com metais pesados tóxicos tem ocorrido em todo o mundo (Dönmez \& Aksu 1999), levando à deterioração de alguns ecossistemas. Para ilustrar a importância da poluição por metais no ambiente, pode-se citar que dentre as 20 substâncias tóxicas com maior risco de causar danos aos seres humanos, em locais contaminados, conforme levantamento realizado em 2001 pela ATSDR (Agency for Toxic Substances and Disease Registry) e EPA (Environmental Protection Agency) do governo dos E.U.A, 5 são metais, incluindo os 3 primeiros lugares da lista.

No Brasil não existe um levantamento abrangente ou estimativas confiáveis do grau do problema de contaminação por metais pesados. No entanto, em função do modelo de crescimento industrial bem como do tipo de indústrias instaladas 
no país, principalmente no Estado de São Paulo, não há motivos para se supor que o problema seja menor do que em países industrializados. Além disto, existem diversos estudos localizados ou regionais que demonstram que a contaminação por metais é um problema sério em algumas regiões, como é o caso do estuário de Santos/São Vicente em SP e as baías de Guanabara e de Sepetiba no RJ (Carvalho et al., 1991; Perin et al., 1997; Amado Filho et al, 1999; Neto et al, 2000).

Talvez o único levantamento mais sistemático e abrangente de contaminação por metais seja o monitoramento que a CETESB (Companhia de Tecnologia de Saneamento Ambiental) realiza nas águas superficiais do Estado de SP (CETESB, 2001a), mas faltam informações sobre o problema de contaminação de solos. Neste sentido, a CETESB recentemente realizou um estudo para determinar valores orientadores quanto à contaminação de poluentes no solo e declarourse a intenção de se realizar levantamentos sistemáticos (CETESB, 2001b). De qualquer modo, a preocupação da CETESB com metais pesados é evidente. Nesse último estudo, das 37 substâncias estudadas, 18 são metais pesados. Além disto, dos 27 parâmetros químicos usados pela CETESB para avaliar a qualidade de águas superficiais do estado, 11 se referem à análise de metais pesados.

As principais fontes de poluição com metais pesados são as diversas atividades de metalurgia, incluindo a mineração, fundição e galvanoplastia (Chaoui et al., 1997a), curtumes (Jordão et al., 1999), gases liberados pela queima de combustíveis fósseis, pesticidas (Gimeno-García et al.,1996; Lagriffoul et al., 1998), utilização de lodo de esgoto para fertilização na agricultura (Chaoui et al., 1997a), aplicação de fertilizantes com impurezas (Chen \& Kao, 1995; Galli et al., 1996; Schickler \& Caspi, 1999) e a fabricação e descarte de baterias (Prasad, 1995; Kefala et al., 1999).

\subsection{Metais pesados em plantas}

Embora impreciso e mal definido, o termo "metal pesado" é comumente usado e aplicado a um grupo heterogêneo de elementos, incluindo metais, semi-metais e 
não metais (Melo et al., 1997) que possuem número atômico maior que 20 ou peso específico maior que $5 \mathrm{~g} . \mathrm{cm}^{-3}$ (Malavolta, 1994). Estes também são conhecidos como "elementos traço", por serem naturalmente encontrados em concentrações de poucas partes por milhão (Mattiazzo-Prezotto, 1994). Alguns metais, como alumínio e berílio, não se enquadram na definição acima, mas mesmo assim são comumente referidos como metais pesados.

O estudo da toxicidade de metais em plantas e microrganismos é importante porque estes se encontram entre os organismos mais afetados pela contaminação por estes elementos. Além disto, apresentam variação quanto à tolerância a metais e apresentam ainda bom potencial para a recuperação de áreas contaminadas por meio de técnicas de biorremediação.

É bem conhecido que metais pesados podem gerar estresse oxidativo. No entanto, o papel do sistema antioxidante no estresse por metais é controverso, com resultados bastante variáveis (Schutzendubel et al., 2001). Os principais motivos disto podem ser:

- os metais apresentam diferentes mecanismos de indução de estresse oxidativo;

- o sistema antioxidante da célula apresenta uma grande diversidade de componentes e é compartimentalizado, diferindo entre os compartimentos e organelas da célula e entre células e tecidos;

- o sistema de desintoxicação/complexação de metais pode reduzir os efeitos dos metais com diferentes intensidades, sendo que o estresse oxidativo pode ser problemático apenas depois que este sistema esteja sobrecarregado. Além disto, a glutationa, um componente bastante importante do sistema antioxidante da célula, também é precursor para a síntese de fitoquelatinas, que são agentes complexantes de metais pesados em vegetais, de maneira que o sistema antioxidante e o sistema de desintoxicação de metais da célula podem ser competitivos entre si.

Com relação a preferências por ligantes, os metais são comumente classificados em ácidos de Lewis duros, moles e intermediários e que formam complexos mais estáveis com ligantes classificados por sua vez como bases de Lewis 
duras, moles e intermediárias, respectivamente. Cada um dos metais acima é representativo de uma destas três classes (Cowan, 1998; da Silva \& Williams, 1991).

Além disto, é de se esperar que as propriedades químicas de cada metal determinem mecanismos diferentes de estresse oxidativo e de resposta à exposição ao mesmo, conforme demonstrado por Cuypers et al. (1999). Por ser elemento de transição, o Ni pode participar de reações de Haber-Weiss (Briat \& Lebrun, 1999), gerando radicais livres diretamente. Dentre os três, é o único que possui diferentes estados de oxidação. $\mathrm{O} \mathrm{Cd}$ e o $\mathrm{Al}$ possuem apenas um estado de oxidação (2+ e 3+, respectivamente) e não são elementos de transição (embora o $\mathrm{Cd}$ seja freqüentemente tratado como tal), pelo menos quanto ao critério de ter um elétron não pareado no seu orbital de valência. Estas propriedades influenciam o mecanismo com o qual cada metal gera estresse oxidativo. Além disto, nenhum dos três é co-fator de enzimas antioxidantes, como é o caso de $\mathrm{Fe}, \mathrm{Mn}, \mathrm{Cu}$ e $\mathrm{Zn}$.

Quanto à importância toxicológica destes metais, o Cd é classificado em 7ํㅡㅁ lugar na lista de substâncias prioritárias quanto ao potencial de dano pela ATSDR e EPA, o $\mathrm{Ni}$ em $53^{\circ}$ e o $\mathrm{Al}$ em $186^{\circ}$. No relatório da qualidade dos recursos hídricos do Estado de São Paulo em 2000 (CETESB, 2001a), os metais pesados que apresentaram as maiores porcentagens de não conformidade foram: cobre, cádmio, chumbo e níquel. Os rios que apresentaram problemas de poluição com $\mathrm{Cd}$ e/ou $\mathrm{Ni}$, seja por poluição pontual devido a efluentes industriais ou poluição difusa devido a insumos agrícolas, foram os rios Capivari, Jundiaí, Atibaia, Piracicaba, Piaçaguera, Mogi e o Alto e Médio Tietê.

O cádmio $(\mathrm{Cd})$ é o principal contaminante ambiental e um dos mais tóxicos entre os metais pesados (Chen \& Kao, 1995). O Cd tem sua concentração aumentada no ambiente devido às atividades humanas de mineração, adubação com lodo de esgoto e efluentes industriais contaminados, fabricação de baterias de automóveis, aplicações militares, aeroespaciais, estabilização de plástico e formulação de pigmentos, entre outros (Prasad, 1995).

O Cd existe na crosta terrestre em baixas concentrações (entre 0,15 e 0,20 $\mathrm{mg} \mathrm{Kg}^{-}$), associado geralmente ao zinco, na forma de depósito de sulfito, de cor prata clara, dúctil e mole. Apresenta peso molecular 112,41 e número atômico 48, com ponto 
de fusão e ebulição, iguais a $321^{\circ} \mathrm{C}$ e $767,2^{\circ} \mathrm{C}$ respectivamete, e densidade de $8,64 \mathrm{~g} / \mathrm{m}^{3}$ (Bernard et al., 1984). Emite vapores, mesmo quando em temperaturas inferiores ao seu ponto de ebulição e em seu estado sólido, sendo insolúvel na água e nos solventes orgânicos usuais e oxidando-se em presença de ar e umidade. $\mathrm{O} \mathrm{Cd}$ pode causar intoxicações agudas em trabalhadores, por exposição direta em seus locais de trabalho e em populações de áreas industriais poluidoras (Lauwerys., 1983; Bernard \& Lauwerys, 1984; Ikeda et al, 2000).

O Cd absorvido pelo homem (e por outros animais) concentra-se em vários órgãos, na urina e no sangue, com valores acima de $80 \%$ de carga corpórea concentrados nos rins, fígado e ossos (Lauwerys., 1983; Bernard \& Lauwerys, 1984, Roels et al., 1999; Ikeda et al., 2000). A vida média biológica do Cd é superior a dez anos (Salt et al., 1995). Por esse motivo, efeitos adversos à saúde podem aparecer mesmo após a redução ou a cessação à exposição ao $\mathrm{Cd}$, como enfizemas pulmonares, desmineralização óssea, destruição dos eritrócitos e câncer (Lewis e al., 1972; Jarup et al., 1988; Ghoshroy et al., 1998).

Quantidades significantes e progressivas deste metal vêm sendo introduzidas no meio ambiente a partir de fontes naturais, estando largamente distribuído na água e no ar contaminados e apresentando um tempo de retenção nos órgãos expresso em décadas (Bernard \& Lauwerys, 1983; Roels et al., 1999; Istomin et al., 1999). É usado em numerosos materiais como revestimento à prova de corrosão, em ligas metálicas, pigmentos, estabilizadores, manufaturas de PVC, fertilizantes fosfatados, baterias de veículos, revestimentos eletrolíticos de metais, acabamentos de peças e fabricação de pedra-pome (Istomin et al., 1999; Kumar et al., 2000).

A exposição ao cádmio pode ser ocupacional ou não. Trabalhadores de indústrias estão sujeitos a inalar o cádmio ou retê-lo em contato com a pele. Exposições não ocupacionais podem ocorrer por meio da ingestão de alimentos e de água. Também o hábito de fumar é uma importante fonte de contaminação para o homem (Shimbo et al., 2000). A carga corporal de cádmio no organismo de indivíduos fumantes é o dobro daquela dos não fumantes, sendo que a média diária de exposição de fumantes ao $\mathrm{Cd}$ oscila entre 2 e $4 \mu \mathrm{g}$ (Lewis et al., 1972). 
No caso das plantas, presença de Cd pode diminuir o crescimento, reduzir a taxa de fotossíntese e provocar alterações tanto enzimáticas quanto metabólicas (Gallego et al., 1996a,b). Isto ocorre devido a alterações provocadas por este metal nas funções dos estômatos, transporte de elétrons, Ciclo de Calvin e desordens na estrutura dos grana e na síntese de clorofila (Barceló et al., 1988). O Cd também afeta a fosforilação oxidativa nas mitocôndrias (Kesseler \& Brand, 1995). Das et al. (1997), observaram que em plantas expostas ao $\mathrm{Cd}$ ocorre a inibição da divisão celular e alterações nos cromossomos. Este metal também pode se ligar a grupos SH de enzimas, inibindo sua atividades (Lagriffoul et al., 1998).

Diversos fatores do meio podem influenciar a absorção do $\mathrm{Cd}$ pela planta, como por exemplo: a concentração do metal no meio, $\mathrm{pH}$ e a espécie de planta (Brown \& Beckett, 1985). Este metal é facilmente absorvido pelo sistema radicular das plantas e translocado, via xilema, para a parte aérea, através da transpiração (Prasad, 1995). De acordo com Melo et al. (1997), o estágio de desenvolvimento da planta e o tempo de exposição ao metal pesado também afetam a absorção e distribuição de $\mathrm{Cd}$ em diferentes partes do vegetal. Também genótipos da mesma espécie podem responder diferentemente quanto à capacidade de absorver e transportar metais pesados dentro do organismo vegetal (Gabbrielli et al., 1990).

$\mathrm{O}$ acúmulo de $\mathrm{Cd}$ em determinados tecidos da planta pode levar a uma rejeição comercial de certos cultivares (Völlegi-Lange \& Wagner, 1996), além de se tornar perigoso à saúde humana (Wagner, 1993). Rauser (1995) relata que mais de 70\% do $\mathrm{Cd}$ absorvido pelo homem tem origem na ingestão de vegetais. Desta forma, as plantas constituem-se no principal ponto de ligação entre metais pesados e o homem, via cadeia dimentar (Galli et al., 1996), tornando-se necessário o estudo do efeito do Cd em plantas.

Diferentes respostas biológicas a metais pesados podem ocorrer devido a diferenças genéticas, ambientais, ou relativas ao crescimento e desenvolvimento (diferenças na expressão gênica). Assim, além de diferenças genotípicas, deve-se considerar a possibilidade de explorar diferenças não genotípicas, ou seja, diferenças 
relativas ao estágio de crescimento e desenvolvimento, que podem ser usadas de modo bastante eficaz como ferramenta de pesquisa.

Diversos trabalhos demonstraram que a sensibilidade e a resposta a metais pesados dependem da idade ou desenvolvimento da planta (Maksymiec, 1997; Skorzynska \& Baszynski, 1997; Skorzynska-Polit et al., 2003) ou do estágio de desenvolvimento de um órgão ou tecido (Krupa \& Moniak, 1998; Maksymiec \& Baszynski, 1996). Em plantas de feijoeiro (Phaseolus coccineus), o acúmulo de homofitoquelatinas em raízes e folhas, em resposta à exposição ao $\mathrm{Cd}$, mostrou-se dependente do estágio de desenvolvimento da planta, sendo maior nas etapas iniciais (Tukendorf et al., 1997). Em gramíneas, o fato das células foliares se encontrarem em diferentes fases de crescimento e desenvolvimento ao longo de uma mesma folha permitiu que se demonstrasse em centeio, a sensibilidade diferencial destas células ao Cd (Krupa, 1998).

Diferenças nos efeitos de $\mathrm{Cd}$ em função do desenvolvimento também foram encontradas em outros organismos, tais como camundongo e camarão (De et al., 1993; Bambang et al., 1995). Em culturas de células vegetais, diferenças na sensibilidade a metais pesados também foram detectadas durante as diferentes fases de crescimento (Larsen, 1989; Kang \& Enger, 1990; Xu \& Vanhuystee, 1993; Vitorello \& Haug, 1996). A toxicidade por $\mathrm{Cd}$ foi correlacionada a mudanças nos níveis de glutationa que ocorreram durante a fase log de crescimento de células de carcinoma de pulmão (Kang \& Enger, 1990).

A sensibilidade a metais também pode depender da fase do ciclo celular (Saplakoglu \& Iscan, 1998; Lee et al., 1998; Sahu et al., 1995; Payette et al., 1995; Francis et al., 1995). Este fato pode ser explorado em pesquisas, tendo em vista a extensão dos estudos sobre o ciclo celular e o fato de que geralmente se trata de populações uniformes de células, sofrendo alterações homogêneas. 


\subsection{Mecanismos de defesa e compostos produzidos por plantas em resposta à exposição a metais pesados}

Conforme revisto, as plantas desenvolveram alguns mecanismos para reduzir a concentração de metais pesados livres no citosol das células os quais incluem: a compartimentalização deste metal em estruturas sub-celulares, exclusão e/ou diminuição do transporte através da membrana e a formação de peptídeos ricos em cisteínas, conhecidos como fitoquelatinas e metalotioneínas, que podem complexar vários metais (Lozano-Rodrígues et al., 1997; Robinson et al., 1990). Além das fitoquelatinas e metalotioneínas, outro mecanismo de defesa desenvolvido pelas plantas e microrganismos para tolerância à exposição aos metais pesados é a produção de um sistema antioxidante de defesa, que inclui componentes de baixa massa molecular tais como glutationa e ascorbato e um sistema de enzimas antioxidantes capazes de remover, neutralizar ou limpar radicais livres e que inclui a superóxido dismutase (SOD), catalase (CAT) e glutationa redutase (GR), entre outros (Scandalios, 1993).

Assim, o estudo da atividade enzimática serve como um critério de avaliação da fitotoxicidade de metais pesados em plantas (Scandalios, 1993). Uma vez sabendo-se a via preferencial de desintoxicação destes metais em plantas pode-se eventualmente traçar estratégias de estudo e melhoramento genético, como por exemplo a manipulação de enzimas que possam condicionar tanto sensibilidade como tolerância a metais em diferentes cultivares. Em todos esses casos, o parâmetro bioquímico a ser analisado poderia ser relativo aos níveis de atividade de enzimas antioxidantes, como CAT, SOD e GR, além de outras como as enzimas do metabolismo do nitrogênio, a Glutamina Sintase e Glutamato Sintetase.

\subsubsection{Sistema oxidante de resposta}

$\mathrm{O}$ acúmulo de oxigênio molecular $\left(\mathrm{O}_{2}\right)$ na atmosfera da Terra permitiu a evolução de organismos aeróbios que utilizam o $\mathrm{O}_{2}$ como aceptor final de elétrons. $\mathrm{O}_{2}$ 
é pouco reativo, mas tem a capacidade de originar estados excitados reativos como radicais livres e derivados (Scandalios, 1993). Este autor relata que a transformação de $\mathrm{O}_{2}$ a $\mathrm{H}_{2} \mathrm{O}$ ocorre pela utilização de 4 elétrons em um ciclo em que são originados espécies intermediárias. Estas EAOs incluem o Radical Superóxido $\left(\mathrm{O}_{2}^{-\bullet}\right)$, Peróxido de Hidrogênio $\left(\mathrm{H}_{2} \mathrm{O}_{2}\right)$, Radical Hidroxila $\left(\mathrm{OH}^{\bullet}\right)$ e Oxigênio "singlet". Em condições de estresse, estas EAOs podem se acumular nos tecidos resultando na alteração da atividade de enzimas como SOD, CAT e peroxidases (POX) (Creissen et al., 1994), as quais são responsáveis pela proteção antioxidante e preservação da integridade da membrana (Lagriffoul et al., 1998).

Os radicais superóxidos são produzidos pela reação do oxigênio molecular do fotossistema na reação de Meyer. Estes $\mathrm{O}_{2}{ }^{\bullet}$ são rapidamente convertidos a $\mathrm{H}_{2} \mathrm{O}_{2}$ pela SOD que está associada ao tilacóide (Allen, 1995). $\mathrm{O} \mathrm{H}_{2} \mathrm{O}_{2}$ pode ser então convertido pela CAT ou pela ascorbato peroxidase (APX) a $\mathrm{H}_{2} \mathrm{O}$ (Fadzillah et al.,1996).

$\mathrm{O} \mathrm{H}_{2} \mathrm{O}_{2}$ produzido pela glicolato peroxidase é degradado pela CAT principalmente nos peroxissomos (Scandalios, 1990; Azevedo et al., 1998). Segundo Foyer et al. (1994), a CAT está ausente no cloroplasto e a degradação do $\mathrm{HO}_{2}$ nos cloroplastos é feita pela APX ligada à membrana do tilacóide. As moléculas de $\mathrm{O}_{2}{ }^{\bullet}$ e $\mathrm{H}_{2} \mathrm{O}_{2}$ que escapam da destruição no tilacóide são destruídas no estroma pela SOD e APX. Radicais monodesidroascorbato produzidos pela APX são convertidos a ascorbato (AA) via ferredoxina (Fd) ou pela enzima Monodesidroascorbato Redutase (MDHAR).

Uma outra alternativa da reação com APX é a formação de ácido ascórbico e ácido desidroascorbato, que podem ser convertidos a ascorbato através da enzima Desidroascorbato Redutase (DHAR), que utiliza a GSH como doador de elétrons. A subsequiente regeneração da glutationa (GSH) requer a participação de GR e NADPH (Allen, 1995). Estas espécies ativas de oxigênio (EAOs) são altamente reativas e citotóxicas para todos os organismos, uma vez que podem reagir com ácidos graxos insaturados das membranas e promover a peroxidação lipídica.

Desta forma, apesar dos organismos aeróbicos disporem de vantagens energéticas significativas utilizando o oxigênio molecular como um oxidante terminal na respiração, a presença do oxigênio no ambiente celular constitui-se numa ameaça 
oxidativa constante às suas próprias estruturas e processos devido ao seu potencial de agir como redutor parcial e assim formar as EAOs (Mallick \& Mohn, 2000), que podem se tornar altamente destrutivas para células e tecidos se sua produção não for estritamente controlada (Rice-Evans et al., 1991). Assim, a formação de EAOs é uma consequiência inevitável do metabolismo dos organismos aeróbicos (Angelova et al., 2000) e provocam "estresse oxidativo" devido à sua ação tóxica e mutagênica sobre as células (Angelova et al., 2000; Mallick \& Mohn, 2000).

Os íons dos metais pesados são capazes de causar danos oxidativos tanto diretamente, agindo como redutores e assim produzindo as EAOs, como indiretamente, inativando o sistema antioxidante da célula (Mannazzu et al., 2000).

Em plantas, a produção das EAOs é favorecida por vários fatores ambientais de estresse como a exposição a níveis elevados de luminosidade, seca, metais pesados, elevada concentração de sais, extremos de temperatura, radiação UV, poluição do ar, herbicidas, estresse físico e mecânico e também como resposta aos estresses bióticos tais como o ataque de patógenos (Mallick \& Mohn, 2000). A produção de EAOs em plantas ocorre também durante a infecção por patógenos e processos fotossintéticos induzidos durante condições abióticas tais como frio, seca e estresses provocados por ozônio e metais pesados (Bowler et al., 1994; Azevedo et al., 1998).

\subsubsection{Superóxido Dismutase (SOD)}

A SOD foi isolada em eritrócitos bovinos em 1938, mas a função desta enzima foi descrita por McCorde e Fridovick (1969). Presente em organismos aeróbios e anaeróbios facultativos esta enzima caracteriza um grupo de metaloenzimas que catalisam a formação de peróxido de hidrogênio $\left(\mathrm{H}_{2} \mathrm{O}_{2}\right)$ a partir de radicais superóxido $\left(\mathrm{O}_{2}^{-\bullet}\right)$ (Figura 1), consumindo-os portanto, e assim, livrando as células do risco de oxidação por esses radicais. A SOD é a primeira enzima de defesa contra danos provocados por EAOs nas células (Alscher et al., 1997; Olmos et al., 2003). 
As SODs são as únicas enzimas cujas atividades interferem nas concentrações de $\mathrm{O}_{2}^{-\bullet}$ e $\mathrm{H}_{2} \mathrm{O}_{2}$, os dois substratos da reação de Haber-Weiss que origina os radicais $\mathrm{OH}^{\bullet}$ e provavelmente por isso, as SODs representam o mecanismo de defesa central dos organismos vivos (Bowler et al., 1992; Alscher et al., 1998; Alscher et al., 2002).

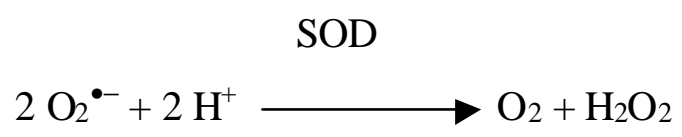

Figura 1 Formação de peróxido de hidrogênio a partir de radicais superóxidos e reação catalisada pela SOD

Estas metaloenzimas multiméricas têm sido classificadas em três grupos de acordo com o componente metálico de seu sítio ativo: cobre/zinco $(\mathrm{Cu} / \mathrm{Zn})$, manganês (Mn) ou ferro (Fe) (Scandalios, 1993; Mattson, 1998; Niyogi, 1999; Mallick \& Mohn, 2000), sendo que as $\mathrm{Cu} / \mathrm{Zn}$-SODs são consideradas as mais abundantes em vegetais (Wingsle et al., 1991). As Cu/Zn-SODs e algumas Mn-SODs e Fe-SODs de procariotos são diméricas, enquanto as Mn-SODs das mitocôndrias e de algumas bactérias termófilas são tetraméricas (Scandalios, 1993).

De acordo com Bowler et al. (1994), Fe-SOD é uma enzima dimérica formada por duas sub-unidades idênticas e está localizada no cloroplasto e a Mn-SOD é uma enzima que possui estrutura similar à Fe-SOD, sendo observada na matriz mitocondrial. Ambas são encontradas em procariontes e eucariontes. Entretanto, a $\mathrm{Cu} / \mathrm{Zn}$-SOD está presente geralmente no citoplasma de células eucarióticas e no cloroplasto.

A Fe-SOD e a Mn-SOD parecem ser muito similares na estrutura primária e tridimensional e em outras propriedades fisico-químicas. A Cu/Zn-SOD não apresenta tal similaridade. Assim, presume-se que tanto a Fe-SOD como a Mn-SOD podem ter um ancestral comum, sendo que a $\mathrm{Cu} / \mathrm{Zn}$-SOD possivelmente evoluiu independentemente (Chen \& Liu, 1996). Bowler et al. (1992) relataram em seus estudos 
de filogenia da SOD que a Mn-SOD e a Fe-SOD são as mais antigas, indicando que provavelmente evoluíram antes da divergência entre procariotos e eucariotos, enquanto que a $\mathrm{Cu} / \mathrm{Zn}-\mathrm{SOD}$, mais recente, evoluiu independentemente em algum ponto no início da linhagem eucariótica, indicando uma dupla evolução desta enzima.

De maneira geral, as $\mathrm{Cu} / \mathrm{Zn}$-SODs são encontradas no citosol e no estroma dos cloroplastos (Hayakawa et al., 1984) e são sensíveis a $\mathrm{CN}^{\top}$ (radical cianeto) (Mallick \& Mohn, 2000). As Mn-SODs e Fe-SODs não são sensíveis ao $\mathrm{CN}^{-}$e têm sido encontradas geralmente na matriz mitocondrial de células eucarióticas e em células procarióticas, embora uma Mn-SOD associada à membrana tenha sido observada nos cloroplastos de algumas plantas (Sehmer \& Dizengremel, 1998). A Fe-SOD foi observada em algumas famílias de plantas e está associada principalmente aos cloroplastos (Mallick \& Mohn, 2000).

Segundo van Camp et al. (1996), as isoenzimas de SOD apresentam grande semelhança entre as diferentes espécies de plantas. Contudo o número e tipo destas isoenzimas varia de planta para planta (Scandalios, 1993). A Cu/Zn-SOD foi encontrada no citosol de arroz (Pan \& Yau, 1991), nas mitocôndrias de girassol (Corpas et al., 1991) e no cloroplasto de arabidopsis (Kliebenstein et al., 1998). A Mn-SOD foi encontrada em mitocôndria de aveia (Sehmer \& Dizengremel, 1998) e em feijão (Corpas et al., 1991). A Fe-SOD é rara em plantas, sendo recentemente encontrada em plantas como Arabidopsis (Kliebenstein et al., 1998) com a função de catalisar a produção de $\mathrm{H}_{2} \mathrm{O}_{2}$ formado durante a $\beta$-oxidação de ácidos graxos e em peroxissomos de folhas verdes durante a fotorrespiração pela transformação do glicolato em glioxilato (Havir \& McHale, 1989).

Em girassol, baixas concentrações de $\mathrm{Cd}$ acarretaram um aumento na atividade de enzimas antioxidantes com exceção da SOD, esta permaneceu inalterada em concentrações mais altas (Gallego et al., 1999). Em folhas de ervilha a atividade de SOD foi significativamente aumentada (Dalurzo et al., 1997). Em altas concentrações de Cd, a atividade de SOD aumentou em Alyssum argenteum e Alyssum maritimum (Gwozdz et al., 1997), Pisum sativum (Dixit t ela., 2001), enquanto em Lupinos luteus, o aumento de sua atividade não foi demonstrado (Gwozdz et al., 1997). 


\subsubsection{Catalase (CAT)}

A catalase descrita em 1901 por Loew (Frugoli et al., 1996), é uma enzima tetramérica que contém grupos heme e é encontrada em todos os organismos vivos. Devido à sua ampla distribuição e capacidade de degradar rapidamente o peróxido de hidrogênio (Figura 2), foi poposto por vários pesquisadores que a CAT desempenha um papel fundamental nos sistemas que capacitam os organismos a viverem em ambientes aeróbicos (Mallick \& Mohn, 2000).

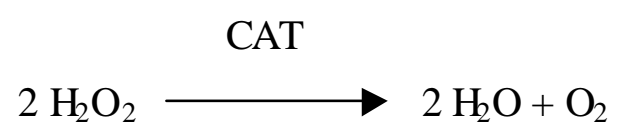

Figura 2- Degradação do peróxido de hidrogênio catalisada pela CAT

A CAT é a única entre as enzimas degradantes de $\mathrm{H}_{2} \mathrm{O}_{2}$ que não consome equivalentes redutores celulares e possui um mecanismo muito eficiente para remover o peróxido de hidrogênio formado nas células sob condições de estresse (Mallick \& Mohn, 2000).

As evidências sugerem que a CAT utiliza mecanismo de dois estágios tanto nas reações peroxidativas como nas catalíticas. No primeiro estágio o ferro do grupo heme da CAT interage com o $\mathrm{H}_{2} \mathrm{O}_{2}$ para formar um peróxido de ferro rico em oxigênio. Este composto intermediário é denominado de componente I. A baixas concentrações de $\mathrm{H}_{2} \mathrm{O}_{2}\left(<10^{-6} \mathrm{~mol} \mathrm{~L}^{-1}\right)$, o componente I pode ser reduzido por uma variedade de doadores de hidrogênio (por exemplo etanol e ácido ascórbico). A elevadas concentrações de $\mathrm{H}_{2} \mathrm{O}_{2}$, o componente I reage com uma segunda molécula de $\mathrm{H}_{2} \mathrm{O}_{2}$ para produzir água e uma molécula de oxigênio (Scandalios, 1994).

Existem três tipos distintos de isoenzimas de CAT identificadas (CAT1, CAT2, CAT3) (Scandalios, 1993). Em plantas a CAT1 é responsável por $80 \%$ da atividade total desta enzima e está localizada no interior dos peroxissomos, sendo 
responsável pela transformação do $\mathrm{H}_{2} \mathrm{O}_{2}$ produzido na fotorrespiração em $\mathrm{H}_{2} \mathrm{O}$ e $\mathrm{O}_{2}$ (Willekens et al., 1997). A CAT2 é encontrada nos tecidos vasculares. A CAT3 está localizada no mesófilo das folhas (Scandalios, 1990). Em plantas, as CATs oncentramse no citoplasma, principalmente nos peroxissomos de folhas e glioxissomos de tecidos que armazenam lipídeos, com exceção da CAT3 de milho e da CAT de algumas algas verdes que são mitocondriais, embora esta última ainda não tenha papel fisiológico totalmente compreendido (Skadsen et al., 1995; Frugoli et al., 1996; Iwamoto et al., 1998).

De acordo com Foyer et al. (1994) a CAT é essencial para destruição de $\mathrm{H}_{2} \mathrm{O}_{2}$ formado na fotorrespiração realizada em plantas C3. Em plantas C4 onde a fotorrespiração é reduzida existe uma diminuição da atividade da CAT. Segundo Willekens et al. (1995), a ausência da atividade da CAT em plantas as tornam mais sensíveis a uma variedade de estresses. Usha-Keshan \& Mukherji (1997), por outro lado, constataram o efeito de $\mathrm{Cd}$ em Vigna radiata e observaram que a CAT apresentou aumento de atividade, mas foi observada também uma redução da atividade fotossintética nesta planta. Em Trema orientalis o efeito do $\mathrm{Ni}$ foi testado por Samantaray et al. (1999), que verificaram um aumento da atividade da CAT na presença deste metal.

Várias condições ambientais podem alterar a atividade da CAT, por exemplo, em um procarioto simbionte fotossintético, Prochloron sp., a atividade da CAT foi diretamente proporcional à irradiação com ultravioleta (Lesser \& Stochaj, 1990). Por outro lado, a mudança na temperatura afetou da mesma forma a atividade da catalase em cianobactéria Synechocystis (Rady et al., 1994).

Culturas de células de algas submetidas a baixa temperatura apresentaram um aumento considerável na atividade de CAT (Mallick \& Rai, 1999). Entretanto, com a elevação da temperatura a atividade foi inibida significativamente. Em relação à exposição ao $\mathrm{Cu}$ e radiação $\mathrm{UV}-\mathrm{B}$, foi observado um aumento expressivo na atividade da CAT na cianobactéria fixadora de $\mathrm{N}_{2}$ Anabaena doliolum e na alga verde Chlorella vulgaris, respectivamente (Mallick \& Rai, 1999; Malanga et al., 1999). 
Em Aspergillus nidulans, duas isoformas de CAT foram identificadas: CAT A, é codificada pelo gene catA, e sua transcrição é induzida especificamente durante a esporulação e em resposta aos diferentes tipos de estresse. A CAT B, é codificada pelo gene catB e está presente no micélio (Calera et al., 2000). A expressão da catB é induzida pelo $\mathrm{H}_{2} \mathrm{O}_{2}$ ou $\mathrm{H}_{2} \mathrm{O}_{2}{ }^{-}$, sem controle regulatório pós-transcricional. As enzimas CAT A e CAT B constituem portanto, mecanismos de defesa antioxidativa alternativos e específicos para os diferentes estágios do ciclo de vida do Aspergillus nidulans (Calera et al., 2000).

O Cd causou um significante decréscimo na atividade de CAT em folhas de Pisum sativum (Dalurzo et al., 1997; Sandalio et al., 2001), plântulas de Helianthus annuus (Bhattacharjee, 1998), Lemna minor (Mohan \& Hossetti, 1997), Amaranthus lividus (Bhattacharjee, 1998), Pinus sylvestris (Schutzendubel, et al., 2001). Em plantas de cana-de-açucar, a atividade de CAT diminuiu (Fornazier et al., 2002). Curiosamente, quando células in vitro de cana-de-açucar foram analisadas (Fornazier et al., 2002b), a atividade de CAT apresentou um rápido aumento com diferentes isoformas de CAT sendo identificadas quando comparadas àquelas identificadas em folhas e raízes (Fornazier et al., 2002a).

\subsubsection{Glutationa Redutase (GR)}

A glutationa reduzida (GSH), é um importante metabólito no combate às EAOs (especificamente $\mathrm{O}_{2}{ }^{-\bullet}$ e $\mathrm{H}_{2} \mathrm{O}_{2}$ ) via o ciclo Halliwell-Asada. Para a regeneração de GSH, a partir da sua forma oxidada (GSSG), a enzima chave é a Glutationa Redutase (GR) (Lee et al., 1998; Lea et al., 1998).

A enzima GR (NADPH: glutationa oxidada) é de ocorrência quase universal, sendo amplamente distribuída entre procariotos e eucariotos, desde bactérias heterotróficas e fotossintetizantes até plantas e animais superiores (Creissen et al., 1994a,b). Em folhas de ervilh, a GR encontra-se presente no cloroplasto, mitocôndrias e compartimentos celulares (Edwards et al., 1990). A GR contém um grupo prostético 
flavina adenina dinucleotídeo (FAD) transferidor de elétrons que catalisa a redução dependente de NADPH da GSSG para GSH (Creissen et al., 1994a,b; Voet \& Voet, 1995), conforme a seguinte reação (Figura 3):

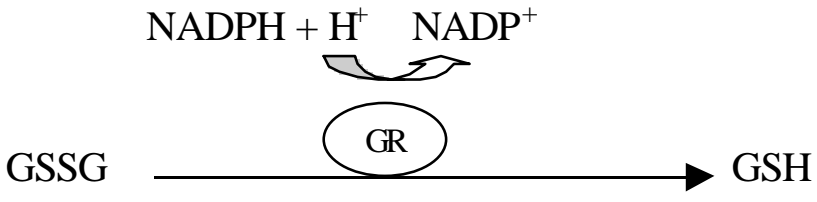

Figura 3- Formação de GSH a partir de GSSG em reação catalisada pela GR

Foram realizados poucos trabalhos estudando a GR em microrganismos, sendo relatado um aumento na atividade desta enzima sob elevada irradiação de UV (Lesser \& Stochaj, 1990), deficiência de água (Smirnoff, 1993) e estresses promovidos por extremos de temperatura (Rady et al., 1994). Em Anabaena doliolum, entretanto, a exposição ao $\mathrm{Cu}$ promoveu um efeito negativo na atividade da GR (Mallick \& Rai, 1999).

Glutationa, $\gamma$-glutamil-cistenil-glicina (GSH) é o componente tiol mais abundante em plantas, sendo considerado essencial para células de plantas e animais contra uma variedade de estresse oxidativos, incluindo poluição do ar, calor, frio e seca (Lea et al., 1998). Fadzillah et al. (1996) verificaram que em plantas de arroz submetidas ao frio ocorreu um aumento da concentração de $\mathrm{H}_{2} \mathrm{O}_{2}$ e mudanças na razão de GSH para GSSG nos tecidos desta espécie

A GSH tem papel importante como antioxidante e na síntese de fitoquelatinas (PCs). Gallego et al. (1996a) e Singhal et al. (1987) sugerem a GSH como a primeira defesa da planta contra a exposição ao $\mathrm{Cd}$. O papel da GSH na tolerância ao metal pesado foi pesquisado por Gallego et al. (1996b), que ao tratarem plantas de girassol com Cd observaram a diminuição do nível de GSH e a indução de PCs 3 dias após o inicio do tratamentos. Segundo Zhu et al. (1999), a alta concentração de GSH em raízes de plantas tem contribuído para aumentar a tolerância ao $\mathrm{Cd}$. Em arroz, o efeito positivo da ação da GSH foi verificado mediante a síntese de fitoquelatinas o que 
conduziu a uma redução do nível de Cd livre nas raízes desta planta (Chen \& Kao, 1995). Chaoui et al. (1997), ao estudarem a ação do Cd em plantas de Brassica juncea ("Indian mustard"), verificaram que na presença deste metal a razão da enzima GR na raiz diminuía e atribuíram este fato à biossíntese de PCs.

As fitoquelatinas (PCs) são peptídeos ricos em cisteína, que são quimicamente poli $(\gamma \text {-glutamil-cisteinil glicina), com a estrutura geral ( } \gamma \text {-Glu-Cys })_{n}$ Gly onde n=2 a 11 (Howden et al., 1995; Mejáre \& Bülow, 2001). Estes peptídeos são sintetizados pela fitoquelatina sintase ( $\gamma$-glutamilcisteina dipeptidiltranspeptidase), que transfere a $\gamma$-glutamilcisteína de uma molécula de GSH para o polímero de $\gamma$-glutamilcisteinil glicina (Grill et al., 1985; Tsuji et al., 2003).

Grill et al. (1985) encontraram que várias espécies de plantas na presença de metais pesados são capazes de sintetizar fitoquelatinas. Entretanto, Leopold et al. (1999) ressaltam que apenas alguns metais pesados podem formar complexos com fitoquelatinas. Em tomate, a ação de metais pesados altera os níveis de PCs tanto em raízes como na parte aérea da planta sendo sugerido que a síntese de PCs pode ser regulada apenas em resposta a exposição ao metal pesado (Chen et al., 1997). Guo \& Marschner (1995) realizaram uma pesquisa com feijão em que foram aplicados os metais $\mathrm{Cd}$ e $\mathrm{Ni}$ e verificaram que o Cd é capaz de induzir a síntese de fitoquelatinas, porém não foi observada uma resposta em relação ao Ni.

A atividade de PC sintase depende da presença de algum íon metálico livre, tal como Cd, Cu, Zn, Ag, Hg ou Pb (Cobbett, 1999), e a complexação desses íons pelas fitoquelatinas recém-sintetizadas, inibe a atividade da PC sintase, atuando como um sistema de auto-regulação enzimática (Goldsbrough, 1998). Essa enzima é expressa constitutivamente em raízes e ramos de tomate, e em cultura de células (Chen et al., 1997). A síntese de PC nas células e tecidos vegetais e sua atividade, podem ser rapidamente induzidas por vários metais, incluindo os cátions $\mathrm{Cd}, \mathrm{Ni}, \mathrm{Cu}, \mathrm{Zn}, \mathrm{Ag}, \mathrm{Hg}$ e $\mathrm{Pb}$ e os ânions $\mathrm{AsO}_{3}{ }^{-3}$ e $\mathrm{SeO}_{3}{ }^{-3}$ (Cobbett, 2000) e as fitoquelatinas são capazes de complexar com vários metais através de ligações tiol. Cerca de $90 \%$ do Cd é acumulado na forma de complexos com PCs (Cd.PC), que se localizam preferencialmente no 
vacúolo de células intactas (Vatamaniuk et al., 2000). Apenas complexos de fitoquelatina com Cd, Cu ou Ag já foram isolados (Maitani et al., 1996).

Genes codificando PC sintase foram caracterizados para Arabidopsis (AtPCS1; Vatamaniuk et al., 1999; CAD1, Ha et al., 1999), trigo (TaPCS1, Clemens et al., 1999) e para a levedura Schizosaccharomyces pombe (Clemens et al., 1999; Ha et al., 1999). Os genes de Arabidopsis e trigo são expressos constitutivamente na ausência de estresse por metais. A indução da expressão do gene de PC sintase em arabidopsis não é afetada pela presença de metais, mesmo em condições severas, sugerindo uma ausência de regulação na transcrição (Ha et al., 1999; Cobbett, 2000), enquanto que a transcrição de TaPCS1 foi induzida em até 10 vêzes na presença de $100 \mathrm{mM}$ de Cd (Clemens et al., 1999). Esses resultados sugerem que, em algumas espécies, a regulação de atividade e transcrição de PC sintase, podem ser controladas por metais aos níveis transcricional ou pós-transcricional.

A GSH pode controlar a quantidade de Cd livre no citosol além de promover a remoção do peróxido de hidrogênio no cloroplasto (El-Shintinawy, 1999; Noctor et al, 2002). De acordo com Creissen et al. (1994a), para realização destas funções, a GSH deve estar na sua forma reduzida, reação esta causada pela GR. Desta forma, a GR tem importante papel na proteção do cloroplasto contra danos oxidativos mantendo a razão entre os níveis de GSH e GSSG (Gallego et al., 1996a,b).

Os genes de GR de ervilha e tabaco foram clonados e seqüenciados (Creissen \& Mullineaux, 1995; Stevens et al.,1997) e mais recentemente clones de cDNA têm sido obtidos a partir de enzimas humanas, o que confirmou a homologia na sequiência de aminoácidos de seres humanos e plantas (Tutic et al., 1990). Porém, dificuldades na purificação e seqüenciamento em plantas superiores têm, até recentemente, impedido algumas comparações diretas entre a seqüência de aminoácido de uma GR de planta e de outros organismos (Creissen et al., 1994a). Entretanto, o efeito de metais pesados sobre a atividade desta enzima em plantas, tem atraído a atenção de muitos pesquisadores. Schickler \& Caspi (1999) mostraram que em plantas do gênero Alyssum altas concentrações deste metal diminuiam a atividade da GR. Em trigo, foi verificado o aumento da atividade da GR na presença do Ni (Pandolfin et al., 1996). 
Inúmeros trabalhos relacionam alterações no conteúdo e atividade dessa enzima em plantas sob condições de estresse por metais pesados, como o aumento na atividade da GR em feijão submetido ao Cd e Zn (Chaoui et al., 1997). Contrariamente, alguns resultados mostraram decréscimo na atividade de GR, como cevada (Patra \& Panda, 1998) e Phragmites australis (Ianelli et al., 2002). Em rabanete, todas as enzimas apresentaram aumentos na atividade com o aumento da concentração e exposição ao $\mathrm{Cd}$, com destaque para a atividade de GR (Vitória et al., 2001). No caso de crotalária (Pereira et al., 2002), a atividade de GR foi bastante elevada nos tratamento com o metal, tanto em raízes como em folhas.

\subsubsection{Glutationa-S-Transferase (GST)}

GSH é doadora de tiol para enzima glutationa-S-transferase (GST) que catalisa a conjugação da glutationa a uma gama de substratos hidrofóbicos eletrofílicos (Dixon et al., 2002). Diversas GSTs foram caracterizadas em animais, associadas a metabolização de compostos xenobióticos e toxinas. A identificação original da GST em vegetais ocorreu devido à sua associação aos mecanismos de resistência ao herbicida Atrazina em milho (Marrs, 1996). Várias outras classes de GST foram identificadas em plantas, após a imposição de diversos tipos de estresses bióticos a abióticos, sendo que muitos cDNAs de GSTs foram clonados empregando abordagens de seleção diferencial ou subtrativa como resposta a estresse (Dixon et al., 2002). Além de participarem em processos de destoxificação por formação de conjugados com GSH, as GSTs possuem papel no metabolismo de produtos secundários, incluindo a estabilização de flavonóides (Marrs, 1996); atuam com peroxidase na redução de hidroperóxidos a monohidróxiálcool durante estresse oxidativo; e no catabolismo de tirosina (Dixon, 2002).

As GSTs são codificadas por uma superfamília de genes, cada uma produzindo isoenzimas com ampla especificidade de substratos. Apesar de catalisarem reações similares, as GSTs possuem pouca identidade de seqüência de aminoácidos, tipicamente entre 25 a $35 \%$ (mesmo dentro da mesma classe), mas regiões com maior 
similaridade ocorrem no terminal amino. Os aminoácidos conservados são provavelmente importantes nas funções comuns, como por exemplo a ligação com GSH ou catálise. Baseado na sequiência prevista de aminoácidos, as GSTs de plantas foram classificadas em quatro classes, denominadas Phi, Zeta, Tau e Theta (Dixon et al., 2002).

Em ervilhas tratadas com Cd, observou-se aumento na atividade de GSTs (Dixit et al., 2001). O gene Bz2 de trigo codifica uma GST responsável por efetuar o último passo na biossíntese de antocianina. A expressão gênica de Bz2 é altamente induzida por metais pesados como Cd. Surpreendentemente, o aumento de mRNA de Bz2 durante o estresse provocado por Cd não resulta no aumento da atividade da GST. Neste caso provavelmente, uma proteína alternativa estaria sendo codificada por Bz2 sob condições de estresse por metais pesados (Marrs \& Walbot, 1997).

\subsubsection{Guaiacol Peroxidase (GPX)}

As peroxidases são hemeproteínas que catalizam a oxidação do substrato concomitantemente à redução do peróxido de hidrogênio. As peroxidases participam de vários processos metabólicos essenciais incluindo regulação do crescimento celular (Goldberg et al.,1986), lignificação, oxidação fenólica, defesa contra patógenos e proteção contra estresses. (Grisebach, 1981).

Nas espécies vegetais e em particular no linho (Linum usitatissimum), a Guaiacol Peroxidase (GPX) apresenta isoformas ácidas e básicas. A isoforma ácida está envolvida numa variedade de processos relacionada com a biossíntese da parede celular, incluindo a formação de lignina. A isoforma básica participa da regulação da degradação do AIA (ácido indol-acético) e da síntese de etileno (Fieldes \& Gerhardt, 1998). 
Em experimentos in vitro, a GPX catalisa a oxidação dos doadores de hidrogênio devido à ausência de substrato específico, no entanto, in vivo a GPX pode utilizar o ascorbato como substrato para suas reações. Neste caso, a destoxificação pode se tornar a função principal de algumas isoformas (Fieldes \& Gerhardt, 1998).

Como exemplos, podemos citar em plantas o aumento na atividade da GPX na presença da radiação UV-B, constatado em Hibiscus rosa-sinensis e Beta vulgaris (Panagopoulos et al., 1989; 1990). O aumento na atividade da enzima GPX pode ser devido à intensificação ou à supressão da atividade de um inibidor natural dessa enzima. Entretanto, na maioria dos organismos, as principais funções das peroxidases não foram bem esclarecidas. Supõe-se que o estudo das alterações provocadas pela indução de estresses fisiológicos possa contribuir para a melhor compreensão da ação específica das isoformas da GPX (C ampa, 1991).

Embora a desintoxicação possa se tornar a função principal de algumas isoformas (Fieldes \& Gerhardt, 1998), na maioria dos organismos, as principais funções das peroxidases não foram bem esclarecidas. Supõe-se que o estudo das alterações provocadas pela indução de estresses fisiológicos poderia contribuir para a melhor compreensão da ação específica das isoformas da GPX (Campa, 1991).

Diversas espécies apresentaram aumento na atividade de enzimas antioxidantes principalmente GPX e APX submetidas ao Cd, ervilha (Dalurze et al., 1997), alga marinha Nannochloropsis oculata (Lee \& Shin, 2003), trigo (Panda et al., 2003) e Arabidopsis thaliana (Skorzynska-Dolit et al., 2003).

\subsection{Nicotiana tabacum cv BY-2}

A cultura de tecidos é um processo através do qual plantas inteiras, órgãos, fragmentos de tecidos (explantes) obtidos de caules, folhas, raízes e ainda células isoladas, quando cultivados assepticamente em meio nutritivo, dão origem a brotos, raízes ou mesmo plantas inteiras. 
A cultura de células por sua vez, envolve o crescimento desorganizado de massas celulares conhecidas como calos, de células indiferenciadas com paredes delgadas e com grandes vacúolos. Células de calos podem manter-se nesse estado por longos períodos se são rotineiramente repicadas para meio novo. Essas células, podem também resultar em plantas regeneradas quando tratadas com uma combinação adequada de fatores de crescimento vegetais.

Esta capacidade das células restabelecerem o crescimento a partir de um estágio latente de diferenciação e iniciar a divisão na presença de concentrações hormonais apropriadas, tem facilitado o cultivo in vitro de espécies de plantas originárias de diferentes fontes teciduais.

Neste segundo aspecto, as linhagens celulares são amplamente utilizadas para estudos de ciclo celulares e em biologia celular de uma maneira geral, por fornecerem uma fonte ilimitada de um tipo geneticamente homogêneo de células.

As linhagens de células vegetais apresentam grande vantagem por serem estabelelecidas de forma relativamente fácil, com obtenção de grandes quantidades a partir de vários tecidos e espécies de plantas superiores o que permite a redução no volume de solução contendo o metal pesado, contribuindo para diminuir a geração de resíduos (Nagata et al., 1992).

Entretanto, a linhagem celular BY-2 (Bright Yellow-2), tem apresentado características únicas, excepcionalmente altos níveis de crescimento e homogeneidade celular (Nagata et al., 1992). A linhagem BY-2 foi a mais proliferativa dos materiais examinados entre quarenta espécies de Nicotiana e três espécies de Populus, sugerindo a presença de características específicas.

A sensibilidade a metais depende do estado fisiológico e de desenvolvimento da célula. $\mathrm{Na}$ linhagem $\mathrm{BY}-2$, é possível promover alterações na sensibilidade ao Al (Vitorello \& Haug, 1996; Yamamoto et al., 1996) e facilitar a obtenção de dados após exposição a agentes genotóxicos como o $\mathrm{Cd}$, por exemplo, devido a possibilidade de se efetuar uma exposição mais uniforme das células ao agente. Dessa forma, tais vantagens tornam a BY-2 uma linhagem amplamente utilizada em 
diversos trabalhos científicos (Nagata et al., 1992; Geelen \& Inzé, 2001; Fojtová et al., 2002, Chaves et al., 2002; Richards et al., 2002, Olmos et al., 2003).

Células BY-2 são utilizadas em estudos do citoesqueleto, regulação do ciclo celular e crescimento celular (Geelen \& Inzé, 2001), na identificação do papel do AMP cíclico como mensageiro secundário, síntese de celulose (Nakagawa \& Sakurai, 1998), síntese de isoprenóides (Andrea et al., 2000), expressão gênica (Yang te al., 2001) e resposta defensiva (Houot et al., 2001).

Como descrito, as células BY-2 apresentam um rápido crescimento e podem ser sincronizadas, sendo úteis para o estudo das biologias celular e molecular de células vegetais. Um importante ponto é que estudos moleculares e subcelulares são facilmente exeqüíveis, principalmente com relação a grande disponibilidade de massa celular proveniente de BY-2. Entretanto, há um laborioso ponto a ser destacado, ou seja, este material deve ser continuamente cultivado em condições apropriadas para a obtenção do crescimento e da sincronização celular. 


\section{MATERIAL E MÉTODOS}

O trabalho foi desenvolvido no Laboratório de Genética Bioquímica de Plantas do Departamento de Genética da Escola Superior de Agricultura 'Luiz de Queiroz" da Universidade de São Paulo (ESALQ-USP) e no Laboratório de Biologia Celular e Molecular do Centro de Energia Nuclear na Agricultura (CENA-USP).

\subsection{Material biológico}

Células não diferenciadas de um sistema modelo importante, Nicotiana tabacum L. cv BY-2 (Bright Yellow-2), foram utilizadas para se testar o efeito do metal Cd. Esta linhagem está estabelecida e vem sendo utilizada no Laboratório de Biologia Celular e Molecular do CENA, onde parte dos experimentos foram desenvolvidos. A linhagem BY-2 é originária da University of Pennsylvania, dos EUA. A suspensão celular foi obtida a partir do mesófilo das folhas de Nicotiana tabacum.

\subsection{Meio de cultura}

\subsubsection{Meio completo líquido}

O preparo do meio de cultura foi realizado como descrito por Nagata et al. (1992) e Vitorello \& Haug (1996).

MES. $.0,5 \mathrm{~g}$

SaisMS [Murashige e Skoog, (1962)] $4,3 \mathrm{~g}$

Sacarose $.30,0 \mathrm{~g}$ 


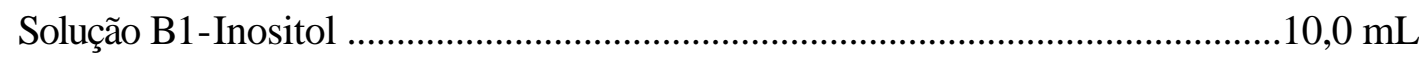

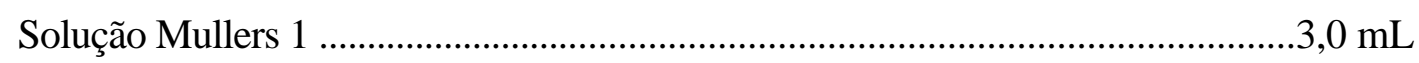

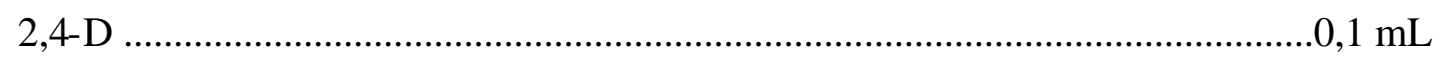

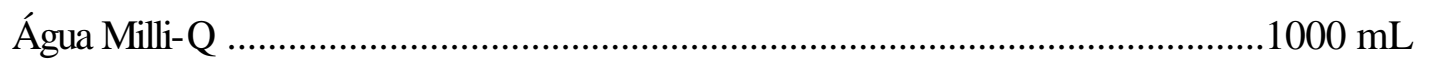

$\mathrm{O} \mathrm{pH}$ foi ajustado para 5,7 com $\mathrm{KOH}$ e o meio esterilizado em autoclave sob $1 \mathrm{~atm}$ por 20 minutos.

\subsubsection{Soluções}

\subsubsection{Solução B1 - Inositol}

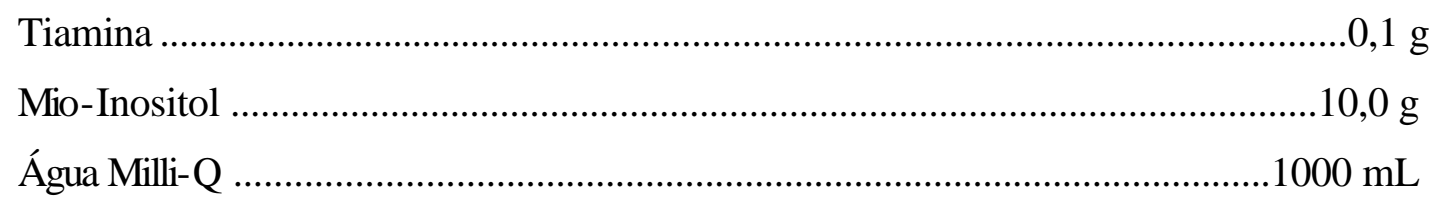

A solução foi distribuída (10 mL) em frascos e congelada.

\subsubsection{Solução Mullers 1}

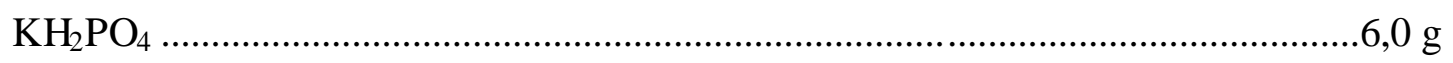

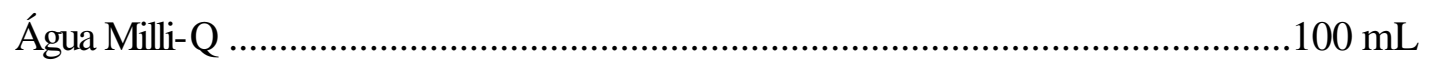

A solução foi distribuída (3 mL) em frascos e congelada.

\subsubsection{2,4-D (estoque $10 \mathrm{mM}$ )}

$2,4-\mathrm{D}$

$. .0,1105 \mathrm{~g}$

Etanol $.0,005 \mathrm{~mL}$

A solução foi distribuída (1 mL) em frascos e congelada. 


\subsection{Cultivo de Células}

As células foram cultivadas rotineiramente como descrito em Nagata et al. (1992) e Vitorello \& Haug (1996). As células foram colocadas em incubadoraagitadora à temperatura de $28^{\circ} \mathrm{C}$ no escuro e subcultivadas em intervalos de 7 dias. $\mathrm{O}$ crescimento celular foi avaliado através do volume de células compactadas após centrifugação a $200 \mathrm{rpm}$.

\subsection{Experimento básico}

Células de Nicotiana tabacum cv BY-2 foram obtidas a partir do inóculo de $3 \mathrm{~mL}$ de suspensão celular por erlenmeyer contendo meio líquido completo e mantidos à $28^{\circ} \mathrm{C}$, por 7 dias.

Inicialmente foram realizados ensaios preliminares para que fossem estabelecidos os períodos de tempo e concentrações de $\mathrm{CdCl}_{2}$ mais adequados. Dessa forma, após toda a caracterização, foram conduzidos experimentos utilizando-se células com 2 dias de crescimento. Neste conjunto de ensaios, o período de exposição ao $\mathrm{Cd}$ foi de $3 \mathrm{~h}, 6 \mathrm{~h}, 12 \mathrm{~h}, 24 \mathrm{~h}, 36 \mathrm{~h}, 48 \mathrm{~h}, 72 \mathrm{~h}$ e $96 \mathrm{~h}$ e as concentrações utilizadas $0 ; 0,1 ; 0,2$ e 0,5 $\mathrm{mM}$ de $\mathrm{CdCl}$.

3.5. Extração e quantificação de aminoácidos para análises por cromatografia líquida de alto desempenho (HPLC) e cromatografia em camada delgada (TLC) 
O procedimento para extração e quantificação de aminoácidos foi baseado na técnica publicada por Bielesky \& Turner (1986), com algumas modificações.

Foram usados 0,1 g de células de BY-2 (matéria fresca) que foram maceradas em $2 \mathrm{~mL}$ da solução de extração MCW $(12 \mathrm{~mL}$ de metanol, $5 \mathrm{~mL}$ de clorofórmio e $3 \mathrm{~mL}$ de água Milli-Q). A mistura foi centrifugada a $2500 \mathrm{rpm}$ por 20 minutos a $4^{\circ} \mathrm{C}$. Após a centrifugação, o sobrenadante foi misturado à $0,5 \mathrm{~mL}$ de clorofórmio e $0,75 \mathrm{~mL}$ de água Milli-Q. Da fase hidrossolúvel coletada, foi retirada uma alíquota para diluição com volume final de $1 \mathrm{~mL}$ (completado com água Milli-Q).

Para a quantificação, foram acrescentados nesta solução de aminoácidos $500 \mu \mathrm{L}$ de tampão citrato $+200 \mu \mathrm{L}$ de ninidrina $+1,0 \mathrm{~mL}$ de solução de $\mathrm{KCN}$. A mistura foi aquecida a $100^{\circ} \mathrm{C}$ por 20 min e em seguida resfriada em água corrente pr 10 min. Posteriormente, $1 \mathrm{~mL}$ de etanol $60 \%$ foi acrescentado na solução. A leitura foi realizada em $\lambda 570 \mathrm{~nm}$ (leitura entre abs 0,400 e 0,800). A concentração de aminoácidos foi estimada segundo a curva padrão de solução de Leucina.

\subsection{Análise de aminoácidos solúveis por cromatografia líquida de alto desempenho} (HPLC).

Os aminoácidos solúveis foram separados e analisados por HPLC de fase reversa. Foi utilizada uma coluna Spherisorb ODS-2 C18 e eluído em um gradiente linear formado pelas soluções de metanol $65 \%$ e tampão fosfato $\mathrm{pH}$ 7,5 (50 mM de acetato de sódio, $50 \mathrm{mM}$ de fosfato disódico, $1,5 \mathrm{~mL}$ de ácido acético, $20 \mathrm{~mL}$ de tetraidrofuran, $20 \mathrm{~mL}$ de metanol) em um fluxo de $0,8 \mathrm{~mL} / \mathrm{min}$. $\mathrm{O}$ gradiente incrementou a proporção de metanol de $20 \%$ a $28 \%$ entre 0 e 5 min, de $28 \%$ a $58 \%$ entre 5 e 35 min, de $58 \%$ a $75 \%$ entre 35 e $40 \mathrm{~min}, 75 \%$ a $95 \%$ entre 40 e 56 min, $95 \%$ a $96 \%$ entre 56 a 60 min e $96 \%$ a $100 \%$ entre 60 e 61 min. O fluído da coluna foi monitorado por um detector de fluorescência Shimatdzu (model RF350) operando com um comprimento de onda de excitação de $250 \mathrm{~nm}$ e um comprimento de onda de emissão de $388 \mathrm{~nm}$. Foram misturados $10 \mu \mathrm{L}$ da solução de aminoácidos e $30 \mu \mathrm{L}$ do reagente OPA. 
Após 2 minutos foram injetados $10 \mu \mathrm{L}$ no aparelho de HPLC. Os dados são expressos em $\mathrm{nmol} / \mathrm{mL}$ do sobrenadante e ou \%mol do total de aminoácidos recuperados (excluindo prolina por não formar um derivado com OPA).

\subsection{Cromatografia em camada delgada (TLC) para aminoácidos}

Para esta análise foram utilizadas placas de sílica gel sobre poliéster de 20 x $20 \mathrm{~cm}$ (Merck). Após a extração e quantificação como descrito em 2.7., alíquotas de $30 \mu \mathrm{L}$ foram aplicadas nas placas para a cromatografia. Antes da aplicação das amostras, as placas foram ativadas à $60^{\circ} \mathrm{C}$ durante 120 minutos em estufa. Os cromatogramas foram desenvolvidos em cuba de vidro contendo solvente constituído de uma mistura de álcool butílico, acetona, hidróxido de amônio e água d.d. nas proporções de 50:50:25:10 $\mathrm{mL}$ respectivamente. Após aproximadamente 4 horas de corrida as placas foram secas em estufa ventilada por 72 horas à temperatura ambiente. Os cromatogramas foram revelados com uma solução de $0,2 \%$ de ninidrina em acetona $(\mathrm{p} / \mathrm{v})$. Padrões foram incluídos para a identificação dos aminoácidos.

\subsection{Extração proteica}

Amostras de cada tratamento foram coletadas e colocadas em um mortar onde foi adicionado nitrogênio líquido, sendo macerado até formar uma farinha, onde posteriormente foi adicionado o tampão de extração ( $1 \mathrm{~g}$ de tecido/ $3 \mathrm{~mL}$ de tampão).

Os materiais vegetais foram homogeneizados em tampão fosfato de potássio $100 \mathrm{mM}$ (pH 7,5) contendo 1mM de EDTA (0,372 g/L tampão), $3 \mathrm{mM}$ de DTT (0,462 g/L tampão) e 4\% (p/v) de PVPP.

$\mathrm{O}$ homogeneizado foi centrifugado à $10.000 \mathrm{rpm}$ por $30 \mathrm{~min}$ à $4^{\circ} \mathrm{C}$. $\mathrm{O}$ sobrenadante coletado, foi dividido em alíquotas as quais foram estocadas em freezer $20^{\circ} \mathrm{C}$ até o momento das análises. 


\subsection{Determinação de proteínas}

O método de Bradford (1976) foi utilizado para as determinações da concentração de proteínas totais durante o projeto, utilizando-se o BSA como padrão.

\subsection{Atividade de enzimas antioxidantes}

Para os ensaios enzimáticos foram utilizados extratos provenientes de amostras de células de Nicotiana tabacum BY-2 expostas à $0,0,1$ e $0,2 \mathrm{mM}$ de $\mathrm{CdCl}_{2}$ nos períodos de $0 \mathrm{~h} ; 3 \mathrm{~h} ; 6 \mathrm{~h} ; 12 \mathrm{~h} ; 24 \mathrm{~h} ; 36 \mathrm{~h} ; 48 \mathrm{~h} ; 72 \mathrm{~h}$ e $96 \mathrm{~h}$.

As amostras foram congeladas de forma progressiva, de $4^{\circ} \mathrm{C}$ a $-20^{\circ} \mathrm{C}$ para posterior extração.

\subsubsection{Atividade de catalase - CAT}

A atividade da CAT foi determinada por dois métodos: espectrofotometria e em PAGE não desnaturante.

\subsubsection{Atividade em espectrofotômetro}

A atividade de catalase foi determinada como descrito por Kraus et al. (1995) com algumas modificações conforme Azevedo et al. (1998). A CAT foi determinada espectrofotometricamente a $25^{\circ} \mathrm{C}$ em uma mistura de reação contendo 1 $\mathrm{mL}$ de tampão fosfato de potássio $(100 \mathrm{mM}) \mathrm{pH} 7,5$ contendo $2,5 \mu \mathrm{L}$ de $\mathrm{H}_{2} \mathrm{O}_{2}$ (solução de 30\%) preparada imediatamente antes do uso. A reação foi iniciada pela adição de 25 
$\mu \mathrm{L}$ de extrato e a atividade determinada seguindo-se a decomposição de $\mathrm{H}_{2} \mathrm{O}_{2}$ por 1 min. através das alterações na absorbância a $240 \eta \mathrm{m}$. Os resultados foram expressos em $\mu \mathrm{mol} / \mathrm{min} / \mathrm{mg}$ de proteína.

\subsubsection{Atividade em PAGE não desnaturante}

Para a determinação da atividade de CAT em PAGE não desnaturante, os extratos vegetais tiveram suas proteínas separadas por eletroforese em gel (8\%). Para a confecção deste gel (com espessura de $3 \mathrm{~mm}, 6,5 \mathrm{~cm}$ de altura e 7,3 $\mathrm{cm}$ de largura), $4 \mathrm{~mL}$ de uma solução $40 \%$ de acrilamida/bis-acrilamida da Sigma foi adicionada a $5 \mathrm{~mL}$ de Tampão TRIS 2,9 M, pH 8,9 e $11 \mathrm{~mL}$ de água. Como catalisadores foram utilizados $38 \mu \mathrm{L}$ de TEMED e $50 \mu \mathrm{L}$ de persulfato de amônio (10\%).

Após a polimerização, $9 \mathrm{~mL}$ de gel de empilhamento foram aplicados sobre o gel principal. Para confeccionar este gel foram utilizados $1 \mathrm{~mL}$ da solução $40 \%$ de acriamida/bis-acrilamida (Sigma), 2,5 mL de Tampão TRIS 500 mM, pH 6,8 e 5,5 $\mathrm{mL}$ de água. Para a polimerização foram utilizados $20 \mu \mathrm{L}$ de TEMED e $100 \mu \mathrm{L}$ de persulfato de amônio (10\%).

A eletroforese foi realizada a $4^{\circ} \mathrm{C}$ e a corrente constante utilizada por placa foi de $20 \mathrm{~mA}$. O tampão de eletrodo foi TRIS 250mM, pH 8,3 acrescido de 1,92 M de glicina. Para cada gel foram aplicadas amostras de padrão de CAT de fígado de boi ( 2 unidades) e $60 \mu \mathrm{g}$ de proteína dos extratos dos tratamentos de $0,0,1$ e $0,2 \mathrm{mM}$ de $\mathrm{CdCl}_{2}$.

A revelação para atividade de CAT foi realizada após a lavagem do gel por 45 min em água deionizada ( 3 x 15 minutos) e incubação do mesmo por 10 minutos em $\mathrm{H}_{2} \mathrm{O}_{2}(0,003 \%)$, à temperatura ambiente, com agitação suave e constante. Após este período, o gel foi rapidamente lavado em água deionizada e colocado por $10 \mathrm{~min} \mathrm{em}$ uma solução de $\mathrm{FeCl}_{3} 1 \%$ (p/v) e $\mathrm{K}_{2} \mathrm{Fe}\left(\mathrm{CN}_{6}\right) 1 \%$ (p/v) sempre com agitação suave. Em seguida, a solução foi retirada e o gel lavado com água. A fixação foi realizada com 
uma solução de ácido acético (7\%).

\subsubsection{Atividade de superóxido dismutase - SOD}

A atividade de SOD foi determinada em PAGE não desnaturante

\subsubsection{Atividade em PAGE não-desnaturante}

Foi realizada a eletroforese em PAGE (8\%) nas mesmas condições como descrito para CAT. Foi utilizado como padrão, duas unidades de SOD de fígado de boi (Sigma) e a concentração de proteínas das amostras foi de $62 \mu \mathrm{g}$. Após a separação das proteínas por eletroforese, a atividade de SOD foi determinada como descrito por Beauchamp e Fridovich (1971). Os géis foram lavados rapidamente em água deionizada e incubados no escuro a temperatura ambiente em uma mistura de reação contendo 50 $\mathrm{mM}$ de tampão fosfato de potássio $\mathrm{pH}$ 7,8, $1 \mathrm{mM}$ EDTA, 0,05 $\mathrm{mM}$ riboflavina, $0,1 \mathrm{mM}$ nitroblue tetrazolium e 0,3\% TEMED. Ao final de $30 \mathrm{~min}$, a mistura de reação foi removida, os géis enxaguados com água deionizada e colocados sob iluminação por alguns minutos até o desenvolvimento de bandas negativas sob fundo roxo. Nestas condições ocorre a fotoxidação do gel, propiciando a formação de uma coloração púrpura e as bandas correspondentes a atividade de SOD permanecem sem se fotoxidar, promovendo uma revelação negativa, assim como para CAT. A fotoxidação foi interrompida mergulhando-se o gel em uma solução de água d.d. e ácido acético (7\%).

\subsubsection{Atividade de glutationa redutase - GR}


A atividade da GR foi determinada por dois métodos: por espectrofotometria e em PAGE não desnaturante.

\subsubsection{Atividade em espectrofotômetro}

A atividade de GR foi determinada como descrito por Smith et al. (1988), com algumas modificações. A atividade de GR foi determinada espectrofotometricamente a $30^{\circ} \mathrm{C}$ em uma mistura de reação consistindo de $3 \mathrm{~mL}$ tampão fosfato de potássio $(100 \mathrm{mM}) \mathrm{pH}$ 7,5 contendo $1 \mathrm{mM}$ DTNB, $1 \mathrm{mM}$ GSSG e 0,1 mM NADPH. A reação foi iniciada pela adição de $50 \mu \mathrm{L}$ de extrato. A atividade da GR foi estimada pela redução de GSSG acompanhada por monitoramento na alteração da absorbância a $412 \eta \mathrm{m}$. Os valores de atividade foram expressos em $\mu \mathrm{mol} / \mathrm{min} / \mathrm{mg}$ de proteína.

\subsubsection{Atividade em PAGE não-desnaturante}

A revelação para atividade de GR foi determinada como descrito por Lee \& Lee (2000). Foi feito o eletroforese em PAGE (8\%) nas mesmas condições como descrito para CAT. Foi utilizado como padrão, uma unidade de GR. Após um tempo médio de $6 \mathrm{~h}$ para eletroforese, os géis foram lavados em água destilada e incubados a temperatura ambiente, em uma solução de $0,25 \mathrm{M}$ de TRIS em pH $7.5(1,514 \mathrm{~g}$ de TRIS); $10 \mathrm{mg}$ MTT; $10 \mathrm{mg}$ DPIP; $2,4 \mathrm{mM}$ GSSG (0,1041g de GSSG) e 0,5 mM NADPH $(0,0208 \mathrm{~g}$ de NADPH). Após o aparecimento das bandas a reação foi interrompida mergulhando-se o gel em uma solução de água d.d. e ácido acético (7\%).

\subsubsection{Determinação da atividade de glutationa -S-transferase - GST}


A atividade da GST foi determinada por espectrofotometria.

\subsubsection{Atividade em espectrofotômetro}

A atividade de GST foi determinada como descrito por Anderson (1985) com algumas modificações por Figueira ${ }^{1}$. O ensaio foi conduzido a $30^{\circ} \mathrm{C}$ em uma mistura de reação contendo $900 \mu \mathrm{L}$ de tampão fosfato de potássio $100 \mathrm{mM} \mathrm{pH} \mathrm{6,5,} \mathrm{e} 25$ $\mu \mathrm{L}$ de CDNB (40 mM). O ensaio foi iniciado pela adição de $50 \mu \mathrm{L}$ de GSH (100 mM) e $25 \mu \mathrm{L}$ de amostra. O monitoramento da absorbância foi feito por $10 \min$ a $340 \eta \mathrm{m}$. A atividade foi expressa em $\mu \mathrm{moL} / \mathrm{min} / \mathrm{mg}$ prot.

\subsubsection{Atividade de guaiacol peroxidase - GPX}

A atividade de GPX foi determinada por espectrofotometria.

\subsubsection{Atividade em espectrofotômetro}

A avaliação da atividade de peroxidase foi determinada de acordo com a técnica descrita por Matsuno \& Uritani (1972), padronizada no Laboratório de Fisiologia Vegetal da Embrapa Clima Temperado. O ensaio foi conduzido em uma mistura de reação contendo $250 \mu \mathrm{l}$ de tampão fosfato-citrato (soluçãode fosfato de sódio dibásico $0,2 \mathrm{M}$ e ácido cítrico $0,1 \mathrm{M}), \mathrm{pH}$ 5,0; $150 \mu \mathrm{L}$ do extrato enzimático e 25 $\mu \mathrm{L}$ de guaiacol a $0,5 \%$, sendo misturados em vortex. Em seguida foram adicionadas 25

$\mu \mathrm{L}$ de $\mathrm{H}_{2} \mathrm{O}_{2}$ e misturadas novamente em vortex. Posteriormente esta mistura foi incubada a $30^{\circ} \mathrm{C}$ po 15 minutos. Em seghidaApós a incubação, a mistura foi colocada

1 Comunicação pessoal 
em banho de gelo adicionando-se a mesma, $25 \mu \mathrm{L}$ da solução de meta bissulfito de sódio a $2 \%$. Após agitação em vortex, a mistura foi deixada em repouso por 10 minutos e a leitura de absorbância em $450 \mathrm{~nm}$. A atividade enzimática foi expressa em $\mu \mathrm{moL}$ $\mathrm{min} / \mathrm{mg}$ prot.

\subsection{Peroxidação de lipídeos}

A peroxidação de lipídeos foi avaliada através da produção de metabólitos reativos a ácido 2-tiobarbitúrico (TBA), principalmente malonaldeído (MDA) baseado nos trabalhos de Heath \& Packer (1968) e Buege \& Aust (1978). Amostras $(0,2 \mathrm{~g})$ foram maceradas com $5 \mathrm{~mL}$ de TCA $(0,1 \%)$ na presença de aproximadamente $20 \%(\mathrm{p} / \mathrm{v})$ de PVPP. Após completa homogeneização, 1,4 mL foi transferido para tubo eppendorf para que fossem centrifugadas a $10.000 \mathrm{rpm}$ por 5 minutos.

Do sobrenadante foi retirado uma alíquota de $0,5 \mathrm{~mL}$ a qual foram adicionados $2 \mathrm{~mL}$ de TCA (20\%) contendo $0,5 \%$ de TBA. A mistura foi deixada em estufa a $95^{\circ} \mathrm{C}$ por 30 min e resfriada em gelo logo em seguida. Após a mudança de cor, 1,4 mL da amostra foram transferidas para tubo eppendorf para centrifugação a 10.000 rpm por $10 \mathrm{~min}$, com o intuito de separar algum resíduo formado durante o aquecimento e também para clarificar um pouco a coloração. As leituras foram realizadas em espectrofotômetro a 535 e $600 \mathrm{~nm}$. A quantidade do MDA foi expressa em $\mathrm{mmoL} / \mathrm{mg}$ de tecido fresco.

\subsection{Delineamento experimental}


Os tratamentos foram dispostos de forma inteiramente casualizada com duas repetições. Aos dados quantitativos obtidos, foi aplicada a análise de variância no programa SAS. 


\section{RESULTADOS}

\subsection{Crescimento e desenvolvimento}

Análises preliminares foram realizadas para que os períodos de exposição e as concentrações fossem determinadas, sendo escolhidos os que melhor indicassem as alterações ocorridas em função do metal. Observa-se na Figura 4, pelo volume de células compactadas, o crescimento gradativo do controle $(0 \mathrm{mM})$ no decorrer do tempo, estabilizando-se após atingir a fase estacionária, por volta de $48 \mathrm{~h}$. A cultura exposta aos tratamentos com $\mathrm{CdCl}$, apresentou redução no crescimento nas concentrações de 0,2 e 0,5 mM. Na concentração de 0,1 mM houve um crescimento e ganho de massa superiores ao controle (Figura 5). O efeito do metal pôde ser comprovado pela análise de viabilidade celular, através da contagem de celulas em lâminas, com o auxílio do corante Trypan Blue (Figura 6). Observa-se também nas Figuras 5 e 7 a mudança nítida de coloração da cultura na presença do metal.

A análise estatística (Tabelas 1 e 4), mostra que as concentrações (Conc), os períodos de tempo (Horas) e a interação entre estes fatores apresentaram pelo menos um valor diferindo da média ao nível de significância $1 \%$. As Tabelas 2 e 5 mostram a mesma análise de variância. Com exceção de 0 horas e 3 horas, todos os demais horários apresentam pelo menos um valor diferindo da média para as diferentes concentrações. Nas Tabelas 3 e 6, pode-se observar que todas as concentrações apresentam pelo menos um valor diferindo da média com relação aos tempos de exposição. 


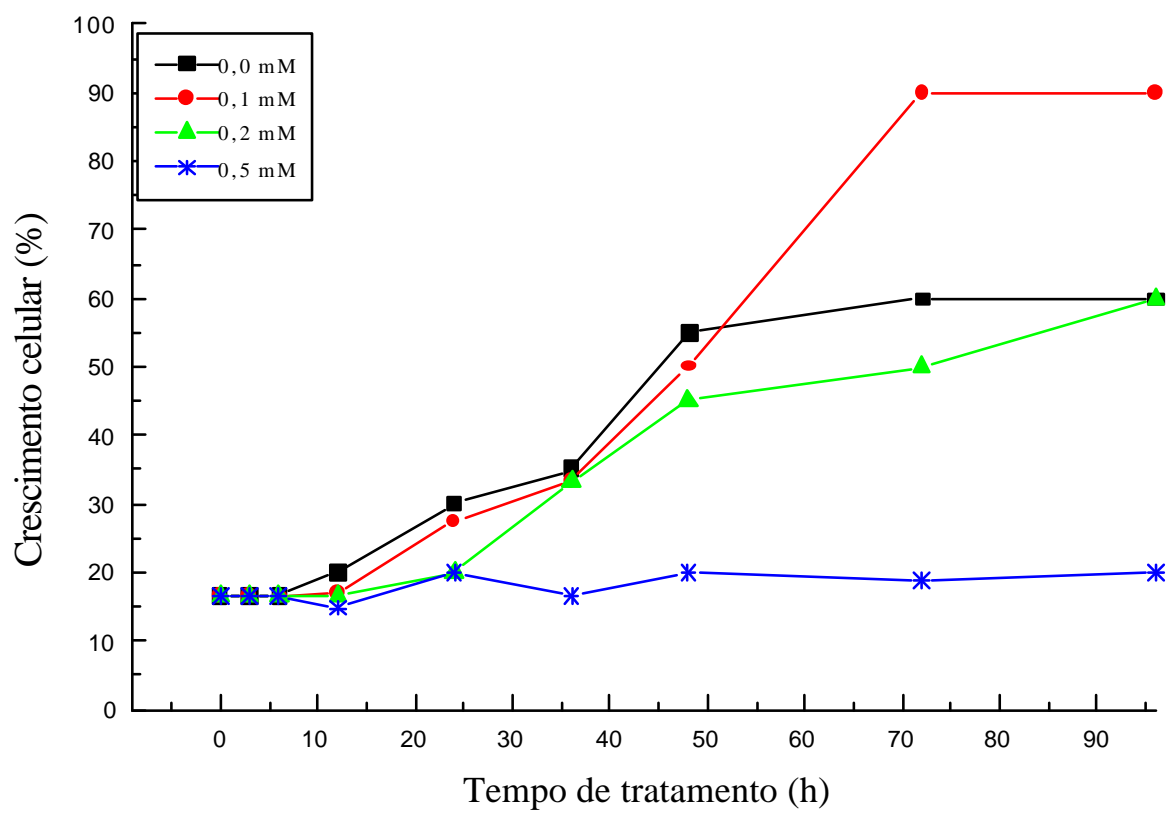

Figura 4- Volume de células compactadas de BY-2 submetidas a concentrações de $\mathrm{CdCl}_{2}$ durante $96 \mathrm{~h}$
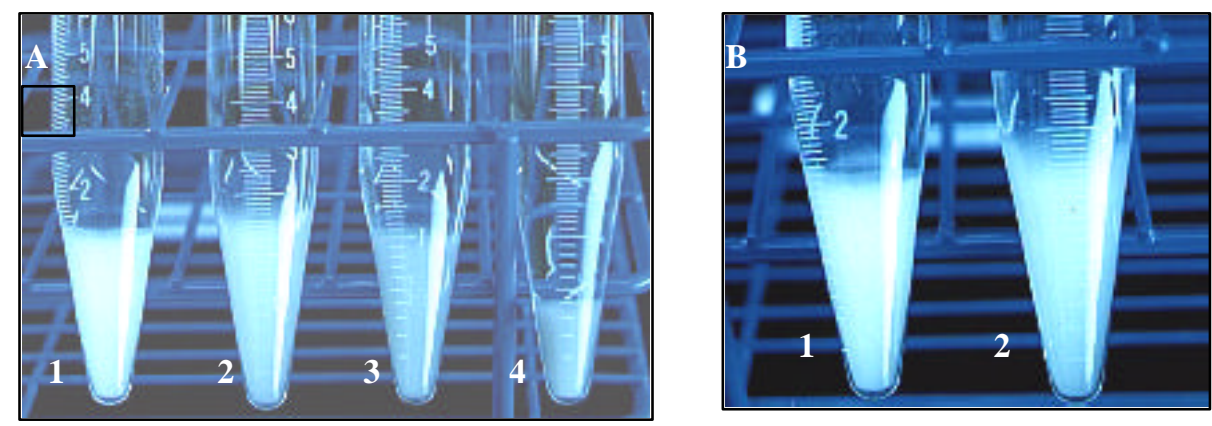

Figura 5- Efeito do metal no crescimento celular nas concentrações (1) $0 \mathrm{mM}$, (2) 0,1 mM, (3) $0,2 \mathrm{mM}$ e (4) $0,5 \mathrm{mM}$ de $\mathrm{CdCb}$ 


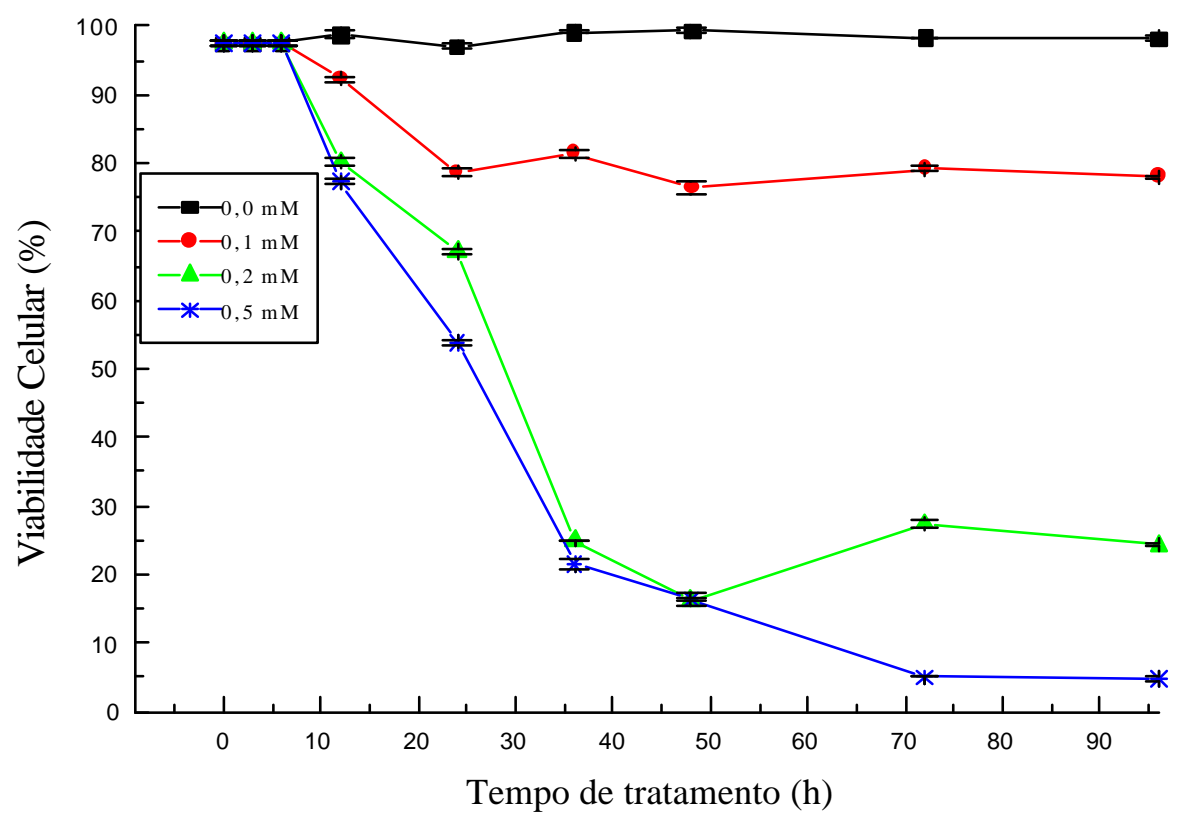

Figura 6- Viabilidade celular da cultura de BY-2 submetidas ao cádmio

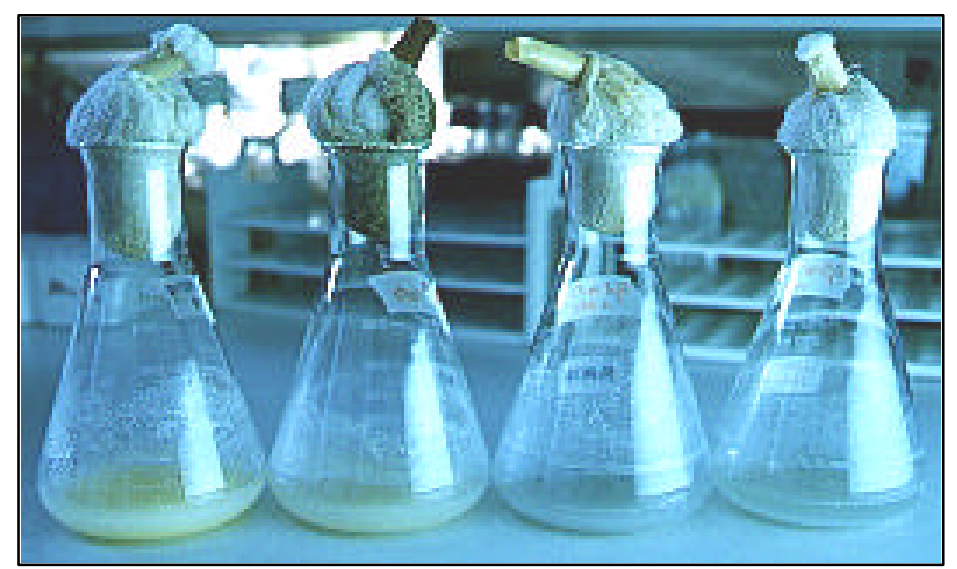

Figura 7- Efeito do metal na coloração das culturas após 48h de exposição nas concentrações (1) $0 \mathrm{mM}$, (2) 0,1 mM, (3) 0,2 $\mathrm{mM}$ e (4) $0,5 \mathrm{mM}$ de de $\mathrm{CdCl}_{2}$ 
Tabela 1. Análise de variância (The SAS System - The GLM Procedure) dos dados provenientes do volume de células compactadas de BY-2

\begin{tabular}{llllll}
\hline FV & GL & SQ & QM & F & Pr $>$ F \\
\hline
\end{tabular}

\begin{tabular}{lrclcl} 
Conc & 3 & 4731,60873 & 1577,20291 & 495745 & $* *<0,0001$ \\
Horas & 8 & 15736,95111 & 1967,11889 & 618303 & $* *<0,0001$ \\
Conc*Horas & 24 & 7423,87017 & 309,32792 & 97227,6 & $* *<0,0001$ \\
\hline
\end{tabular}

* 5\% de significância; ** 1\% de significância $\quad \mathrm{CV}=0,1841129$

Tabela 2. Análise de variância dos dados da tabela 1 com desdobramento do fator horas

\begin{tabular}{lccllr}
\hline FV & GL & SQ & QM & F & Pr $>$ F \\
\hline 0 horas & 3 & $1,081866 \mathrm{E}-27$ & $3,606221 \mathrm{E}-28$ & 0,00 & 1,0000 \\
3 horas & 3 & $1,456913 \mathrm{E}-27$ & $4,856378 \mathrm{E}-28$ & 0,00 & 1,0000 \\
6 horas & 3 & 0,036571 & 0,012190 & 3,83 & $* 0,0209$ \\
12 horas & 3 & 28,885836 & 9,628612 & 3026,46 & $* *<0,0001$ \\
24 horas & 3 & 137,500000 & 45,833333 & 14406,3 & $* *<0,0001$ \\
36 horas & 3 & 432,784171 & 144,261390 & 45344,1 & $* *<0,0001$ \\
48 horas & 3 & 1442,857143 & 480,952381 & 151172 & $* *<0,0001$ \\
72 horas & 3 & 5170,558036 & 1723,519345 & 541735 & $* *<0,0001$ \\
96 horas & 3 & 4942,857143 & 1647,619048 & 517878 & $* *<0,0001$ \\
\hline
\end{tabular}

Tabela 3. Análise de variância da tabela 1 com desdobramento do fator concentração

\begin{tabular}{|c|c|c|c|c|c|}
\hline FV & GL & SQ & QM & $\mathrm{F}$ & $\operatorname{Pr}>\mathrm{F}$ \\
\hline $0 \mathrm{mM}$ & 8 & 5812,533511 & 726,566689 & 228374 & $* *<0,0001$ \\
\hline $0,1 \mathrm{mM}$ & 8 & 14943 & 1867,835339 & 587096 & $* *<0,0001$ \\
\hline $0,2 \mathrm{mM}$ & 8 & 2345,166756 & 293,145844 & 92141,3 & $* *<0,0001$ \\
\hline $0,5 \mathrm{mM}$ & 8 & 60,438300 & 7,554788 & 2374,61 & $* *<0,0001$ \\
\hline
\end{tabular}


Tabela 4. Análise de variância (The SAS System - The GLM Procedure) dos dados provenientes das análises de viabilidade celular

\begin{tabular}{lrrlrl}
\hline FV & GL & SQ & QM & F & Pr $>$ F \\
\hline Conc & 3 & 23945,77036 & 7981,92345 & $4,162 \mathrm{E} 7$ & $* *<0,0001$ \\
Horas & 8 & 19739,81569 & 2467,47696 & $1,287 \mathrm{E} 7$ & $* *<0,0001$ \\
Conc*Horas & 24 & 17517,07975 & 729,87832 & 3805855 & $* *<0,0001$
\end{tabular}

* 5\% de significância; ** 1\% de significância $\quad \mathrm{CV}=0,018259$

Tabela 5. Análise de variância da tabela 4 com desdobramento do fator horas

\begin{tabular}{lccccc}
\hline FV & GL & SQ & QM & F & Pr $>$ F \\
\hline 0 horas & 3 & $6,736421 \mathrm{E}-27$ & $2,245474 \mathrm{E}-27$ & 0,00 & 1,0000 \\
3 horas & 3 & 0,00035714 & 0,000011905 & 0,06 & 0,9793 \\
6 horas & 3 & 41,530752 & 13,843584 & 72185.5 & $* *<0,0001$ \\
12 horas & 3 & 494,248600 & 164,749533 & 859065 & $* *<0,0001$ \\
24 horas & 3 & 1967,764643 & 655,921548 & 3420217 & $* *<0,0001$ \\
36 horas & 3 & 8239,123343 & 2746,374448 & $1,432 \mathrm{E} 7$ & $* *<0,0001$ \\
48 horas & 3 & 9314,316486 & 3104,772162 & $1,619 \mathrm{E} 7$ & $* *<0,0001$ \\
72 horas & 3 & 10543 & 3514,477908 & $1,833 \mathrm{E} 7$ & $* *<0,0001$ \\
96 horas & 3 & 10862 & 3620,810840 & $1,888 \mathrm{E} 7$ & $* *<0,0001$ \\
& & & & & \\
\hline
\end{tabular}

Tabela 6. Análise de variância da tabela 4 com desdobramento do fator concentração

\begin{tabular}{lrrrrr}
\hline FV & GL & SQ & QM & F & Pr $>$ F \\
\hline $0,0 \mathrm{mM}$ & 8 & $10, .897300$ & 1,362163 & 7102,82 & $* *<0,0001$ \\
$0,1 \mathrm{mM}$ & 8 & 1299,455353 & 162,431919 & 846980 & $* *<0,0001$ \\
$0,2 \mathrm{mM}$ & 8 & 9852,220822 & 1231,527603 & 6421639 & $* *<0,0001$ \\
$0,5 \mathrm{mM}$ & 8 & 26094 & 3261,790245 & $1,701 \mathrm{E} 7$ & $* *<0,0001$ \\
\hline
\end{tabular}




\subsection{Cromatografia líquida de alto desempenho (HPLC) e cromatografia em camara delgada (TLC)}

As cromatografias (HPLC e TLC) evidenciaram alterações nos aminoácidos solúveis nas concentrações de 0,1 e $0,2 \mathrm{mM}$ de $\mathrm{CdCl}_{2}$ (Figura 8 e Tabela 7), com aumento e diminuição na concentração de alguns aminoácidos. Pela análise da Tabela 3 observou-se que ocorreu a predominância de GLI nas células que foram submetidas a concentração mais baixa de cádmio, ou seja $0,1 \mathrm{mM}$.

No caso de SER, houve apenas presença deste aminoácido a partir de $24 \mathrm{~h}$ nas células com $0,1 \mathrm{mM}$ de $\mathrm{CdCh}$, diferentemente do controle $(0 \mathrm{mM})$, onde praticamente não foi observada e na concentração mais alta $(0,2 \mathrm{mM})$, onde todos o horários, com exceção apenas de $6 \mathrm{~h}$, apresentaram SER.

No caso de TIR, tanto as as células com $0 \mathrm{mM}$ e $0,2 \mathrm{mM}$ de $\mathrm{CdCl}_{2}$ apresentaram este aminoácido em contraposição a concentração mais baixa, $0,1 \mathrm{mM}$, onde a sua presença só foi verificada a partir de $36 \mathrm{~h}$ de exposição ao metal.

As concentrações de $\mathrm{CdCl}_{2}$ 0,1 $\mathrm{mM}$ e 0,2 $\mathrm{mM}$ também apresentaram uma composição do aminoácido ALA diferente daquela referente ao controle $(0 \mathrm{mM} \mathrm{CdCh})$.

Para LEU e LIS, os tratamentos $\left(0 \mathrm{mM}, 0,1 \mathrm{mM}\right.$ e $0,2 \mathrm{mM}$ de $\left.\mathrm{CdCl}_{2}\right)$ apresentaram-se com oscilações entre os horários na concentração destes aminoácidos.

O resultado apresentado na Figura 9 demonstra que há variação na composição de aminoácidos solúveis totais. Inicialmente a queda na composição possivelmente em função do estresse foi maior para a concentração mais alta utilizada de metal $(0,2 \mathrm{mM})$ comparada a concentração mais baixa $(0,1 \mathrm{mM})$. Observou-se também aumento diferencial na composição aminoacídica nas concentrações nos períodos posteriores de exposição. $\mathrm{Na}$ concentração de $0,2 \mathrm{mM}$ observou-se que esta composição manteve-se alta após o período de 12 horas, contrariamente a concentração de $0,1 \mathrm{mM}$. 

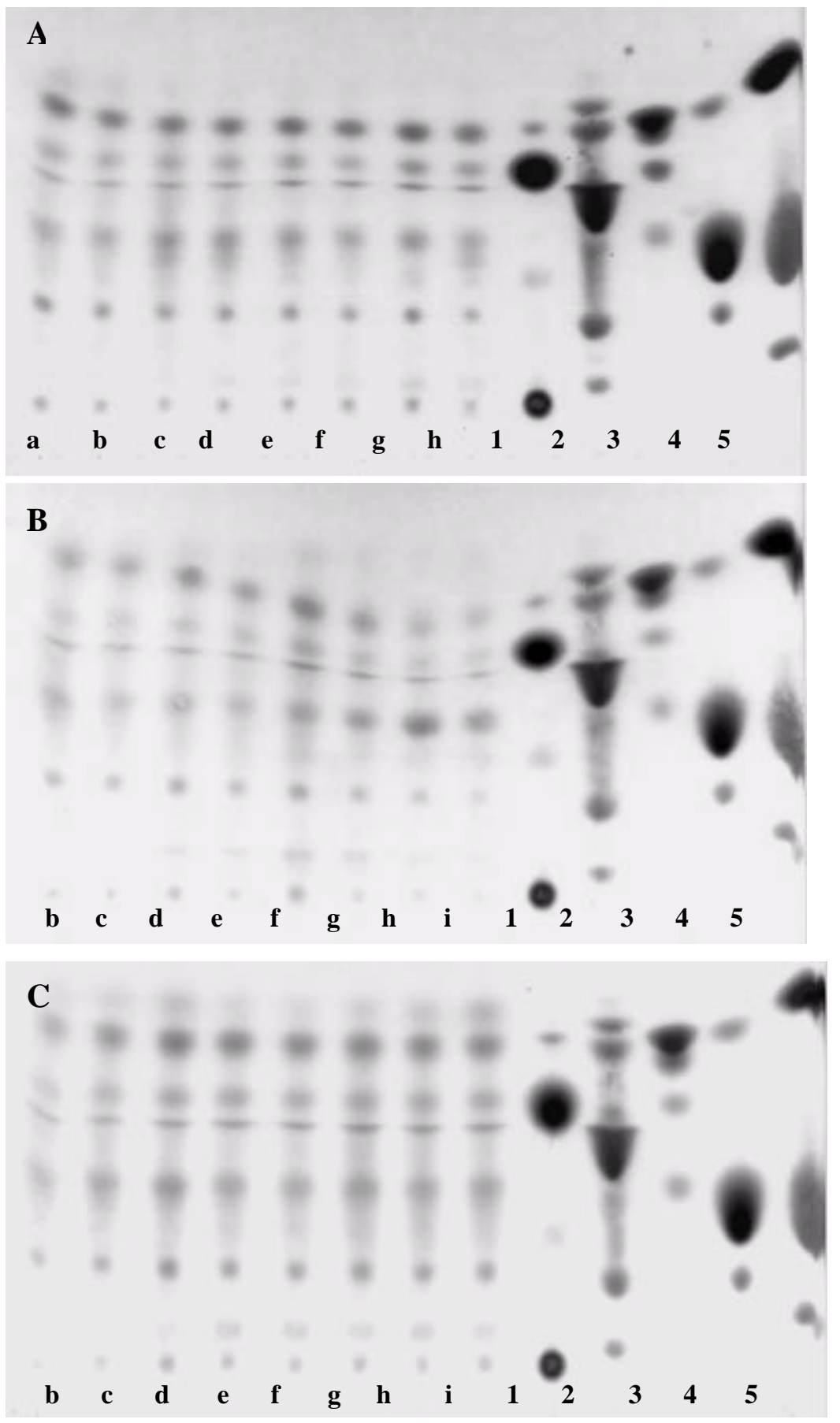

Figura 8- Cromatografia de camada delgada; (A) $0 \mathrm{mM}$, (B) $0,1 \mathrm{mM} \mathrm{e} \mathrm{(C)} \mathrm{0,2} \mathrm{mM}$ de $\mathrm{CdCh}_{2}$; (a) $0 \mathrm{~h}$, (b) $3 \mathrm{~h}$, (c) $6 \mathrm{~h}$, (d) $12 \mathrm{~h}$, (e) $24 \mathrm{~h}$, (f) $36 \mathrm{~h}$, (g) $48 \mathrm{~h}$, (h) $72 \mathrm{~h} \mathrm{e}$ (i) $96 \mathrm{~h}$; (1), (2), (3), e (4) padrões de aminoácidos 
Tabela 7. Composição aminoacídica (nmol/ $\mu \mathrm{l}) ; 0 \mathrm{mM}, 0,1 \mathrm{mM}$ e 0,2 mM de CdCb

\begin{tabular}{|c|c|c|c|c|c|c|c|c|c|c|c|c|c|c|c|}
\hline \multirow{2}{*}{$\begin{array}{l}\text { BY-2 } \\
0 \mathrm{mM}\end{array}$} & $\mathrm{SP}$ & \multicolumn{2}{|c|}{ SLU SER } & \multicolumn{2}{|c|}{ HYS GLY } & \multirow[t]{2}{*}{ THR } & \multirow[t]{2}{*}{ ARG } & \multirow[t]{2}{*}{ ALA } & \multirow[t]{2}{*}{ TYR } & \multirow[t]{2}{*}{ MET } & \multirow[t]{2}{*}{ VAL } & \multirow[t]{2}{*}{ PHE } & \multirow[t]{2}{*}{ TLE } & \multirow[t]{2}{*}{ LEU } & \multirow[t]{2}{*}{ LYS } \\
\hline & & & & & & & & & & & & & & & \\
\hline $0 \mathrm{~h}$ & 1365 & 356 & 132 & 590 & 102 & 429 & 620 & 1167 & 382 & 197 & 775 & 841 & 409 & 1636 & 1321 \\
\hline $3 \mathrm{~h}$ & 1249 & 264 & - & 455 & 145 & 348 & 361 & 735 & 325 & 236 & 577 & 544 & 330 & 1103 & 1330 \\
\hline $6 \mathrm{~h}$ & 759 & - & - & 240 & - & 239 & 262 & 478 & 273 & 187 & 357 & 354 & 283 & 712 & 1871 \\
\hline $12 \mathrm{~h}$ & 161 & - & - & - & - & 76 & 111 & 157 & 87 & 79 & 120 & 120 & 117 & 179 & 584 \\
\hline $24 \mathrm{~h}$ & 1020 & 274 & - & 428 & 88 & 196 & 235 & 633 & 261 & 176 & 428 & 382 & 243 & 731 & 337 \\
\hline $36 \mathrm{~h}$ & 873 & 258 & - & 304 & - & 196 & 216 & 468 & 261 & 190 & 508 & 436 & 287 & 850 & 473 \\
\hline $48 \mathrm{~h}$ & 855 & 182 & - & 260 & 59 & 172 & 178 & 335 & 225 & 154 & 382 & 339 & 212 & 614 & 293 \\
\hline $72 \mathrm{~h}$ & 596 & 240 & - & 260 & 39 & 230 & 215 & 384 & 292 & 219 & 628 & 473 & 388 & 959 & 281 \\
\hline $96 \mathrm{~h}$ & 657 & 288 & - & 313 & 85 & 319 & 195 & 392 & 331 & 169 & 650 & 442 & 376 & 728 & - \\
\hline \multicolumn{16}{|l|}{$0,1 \mathrm{mM}$} \\
\hline $3 \mathrm{~h}$ & 971 & - & - & 448 & 231 & 215 & 288 & - & - & 167 & 289 & 389 & 270 & 783 & 1413 \\
\hline $6 \mathrm{~h}$ & 506 & 170 & - & 253 & 450 & 146 & 232 & - & - & 185 & 268 & 360 & 266 & 663 & 972 \\
\hline $12 \mathrm{~h}$ & 445 & 219 & - & 189 & 377 & 169 & 209 & 57 & - & 117 & 265 & 354 & 206 & 665 & - \\
\hline $24 \mathrm{~h}$ & 394 & 140 & 241 & 143 & 332 & 105 & 186 & - & - & 117 & 236 & 282 & 210 & 582 & 608 \\
\hline $36 \mathrm{~h}$ & 912 & 242 & 168 & 606 & 179 & 259 & 253 & 639 & 351 & 239 & 472 & 600 & 317 & 1156 & 831 \\
\hline $48 \mathrm{~h}$ & 868 & 122 & 435 & 443 & 120 & 159 & 118 & 739 & 190 & 111 & 257 & 319 & 159 & 609 & - \\
\hline $72 \mathrm{~h}$ & 857 & - & 279 & 373 & 200 & 184 & 87 & 1486 & 690 & 79 & 224 & 172 & 124 & 374 & - \\
\hline \multicolumn{16}{|c|}{$0.2 \mathrm{mM}$} \\
\hline $96 \mathrm{~h}$ & 807 & 155 & 158 & 332 & 67 & 205 & 75 & - & 498 & 76 & 195 & 162 & 112 & 346 & - \\
\hline $3 \mathrm{~h}$ & 768 & 143 & 183 & 346 & 55 & 255 & 145 & 325 & 150 & 120 & 198 & 257 & 141 & 487 & 400 \\
\hline $6 \mathrm{~h}$ & 622 & 181 & - & 263 & 67 & 177 & 225 & 484 & 230 & 186 & 328 & 408 & 221 & 806 & 256 \\
\hline $12 \mathrm{~h}$ & 625 & 394 & 230 & 520 & 205 & 334 & 531 & 870 & 445 & 322 & 596 & 821 & 469 & 1519 & 848 \\
\hline $24 \mathrm{~h}$ & 480 & 290 & 403 & 358 & - & 232 & 267 & 546 & 325 & 250 & 509 & 504 & 360 & 1075 & 696 \\
\hline $36 \mathrm{~h}$ & 872 & 280 & 418 & 641 & 169 & 224 & 241 & 467 & 314 & 227 & 442 & 443 & 331 & 929 & 335 \\
\hline $48 \mathrm{~h}$ & 922 & 209 & 367 & 743 & - & 260 & 282 & 636 & 318 & 290 & 514 & 550 & 378 & 1155 & 1742 \\
\hline $72 \mathrm{~h}$ & 888 & 288 & 494 & 611 & 133 & 292 & 254 & 115 & 333 & 195 & 473 & 448 & 301 & 952 & 458 \\
\hline $96 \mathrm{~h}$ & 720 & 255 & 326 & 511 & - & 317 & 227 & 524 & 309 & 194 & 425 & 421 & 301 & 921 & 1030 \\
\hline
\end{tabular}




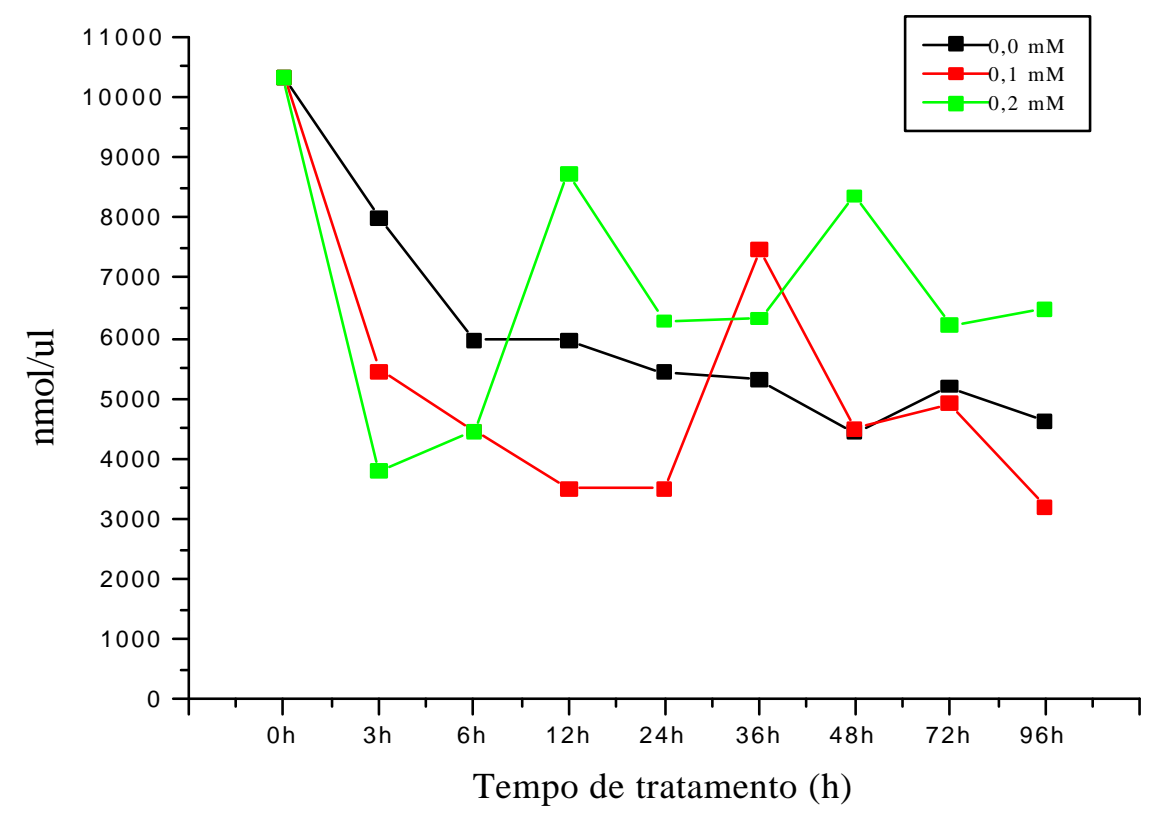

Figura 9- Aminoácidos solúveis totais de células da cultura de BY-2, submetidas a diferentes concentrações de $\mathrm{CdCb}$ 


\subsection{Atividade de CAT em espectrofotômetro e em PAGE não-desnaturante}

As atividades das enzimas antioxidantes foram determinadas para as concentrações de $0,1 \mathrm{mM}$ e $0,2 \mathrm{mM}$ de $\mathrm{CdCh}$, visto que o efeito da concentração de 0,5 $\mathrm{mM}$ de $\mathrm{CdCh}$ causou severa inibição do crescimento e multiplicação celular.

A atividade da catalase (Figura 10) em células BY-2 apresentou variações significativas durante o período de tratamento em relação ao controle. Na concentração de $0,1 \mathrm{mM}$, inicialmente (12h) ocorreu um pequeno aumento da atividade. Após este período, ocorreu uma diminuição de atividade até $48 \mathrm{~h}$ e subsequente aumento progressivo até $72 \mathrm{~h}$ com queda posterior às $96 \mathrm{~h}$ de exposição. Na concentração de 0,2 $\mathrm{mM}$, houve uma queda brusca de atividade seguida de um restabelecimento que se manteve đé $72 \mathrm{~h}$, mais proeminente que na concentração $0,1 \mathrm{mM}$, com posterior queda na atividade até as $96 \mathrm{~h}$.

A atividade da CAT em PAGE não desnaturante (Figura 11) seguiu essencialmente o padrão na análise em espectrofotômetro para o controle $(0 \mathrm{mM}$ de $\mathrm{CdCl}_{2}$ ), ou seja um decréscimo constante da atividade a partir de $48 \mathrm{~h}$. Esta análise permitiu a identificação de CAT nas células de tabaco.

A análise estatística (Tabela 8), mostra que as concentrações (Conc), os períodos de tempo (Horas) e a interação entre estes fatores apresentaram pelo menos um valor diferindo da média ao nível de significância $1 \%$. A Tabela 9 mostra a mesma análise de variância, sendo possível observar que com exceção de $0 \mathrm{~h}$, todos os demais horários apresentam pelo menos um valor diferindo da média para as diferentes concentrações. Na Tabela 10, pode-se observar que todas as concentrações apresentam pelo menos um valor diferindo da média com relação aos tempos de exposição. 


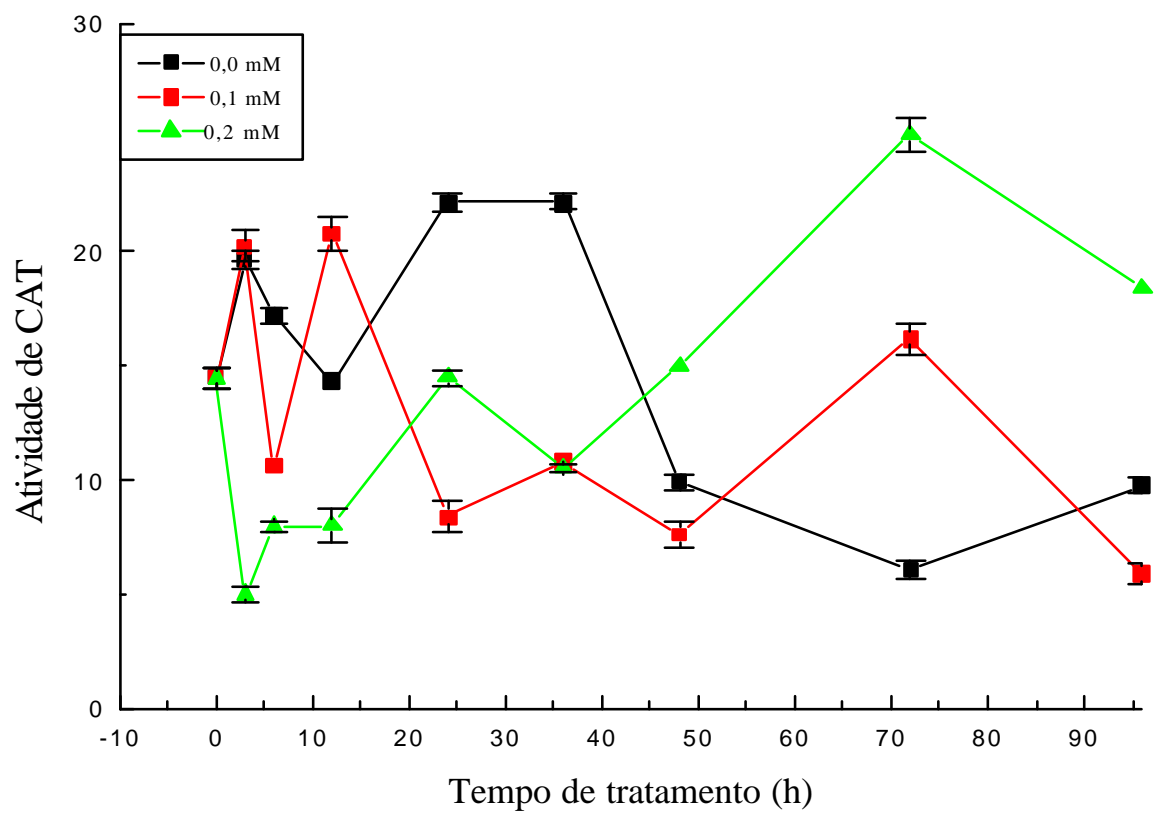

Figura 10- Atividade esapecífica de CAT ( $\mu \mathrm{mol} / \mathrm{min} / \mathrm{mg}$ prot) em células de BY-2 submetidas à diferentes concentrações de $\mathrm{CdCl}_{2}$

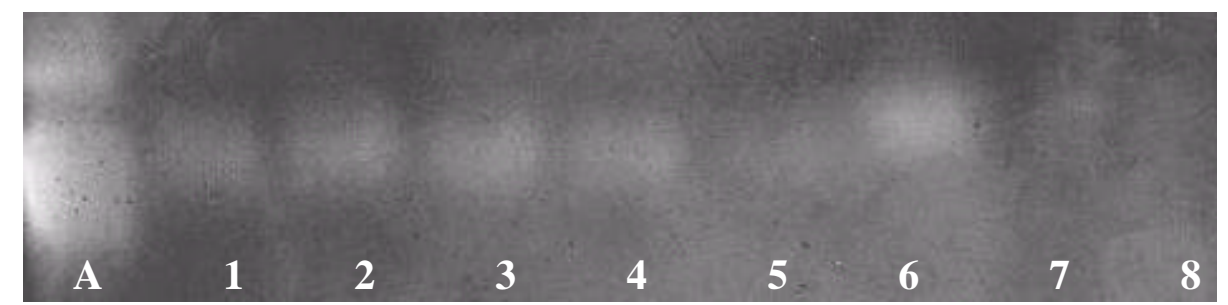

Figura 11 Atividade de CAT em PAGE não-denaturante de células BY-2 submetidas a tratamentos com $0 \mathrm{mM}$ de $\mathrm{CdCl}$, por (1) $0 \mathrm{~h}$, (2) $3 \mathrm{~h}$, (3) $6 \mathrm{~h}$, (4) $12 \mathrm{~h}$, (5) 24 h, (6) 36 h, (7) 48 h e (8) 72h; (A) padrão de CAT bovina 
Tabela 8. Análise de variância (The SAS System - The GLM Procedure) dos dados provenientes da atividade de CAT em espectrofotômetro

\begin{tabular}{lrrlrl}
\hline FV & GL & \multicolumn{1}{c}{ SQ } & QM & F & Pr $>$ F \\
\hline Conc & 2 & 52,113235 & 26,056617 & 37052,0 & $* *<0,0001$ \\
Horas & 8 & 157,913406 & 19,739176 & 28068,7 & $* *<0,0001$ \\
Conc*Horas & 16 & 1444,162170 & 90,260136 & 128348 & $* *<0,0001$ \\
\hline
\end{tabular}

* 5\% de significância; ** 1\% de significância $\quad \mathrm{CV}=0,193344$

Tabela 9. Análise de variância da tabela 8 com desdobramento do fator horas

\begin{tabular}{lccccc}
\hline FV & GL & SQ & QM & F & Pr $>$ F \\
\hline 0 horas & 2 & $1,434453 \mathrm{E}-11$ & $7,172267 \mathrm{E}-12$ & 0,00 & 1,0000 \\
3 horas & 2 & 295,555297 & 147,777648 & 210137 & $* *<0,0001$ \\
6 horas & 2 & 88,984675 & 44,492338 & 63267,3 & $* *<0,0001$ \\
12 horas & 2 & 162,786061 & 81,393030 & 115739 & $* *<0,0001$ \\
24 horas & 2 & 189,610642 & 94,805321 & 134811 & $* *<0,0001$ \\
36 horas & 2 & 176,753221 & 88,376610 & 125670 & $* *<0,0001$ \\
48 horas & 2 & 56,235949 & 28,117974 & 39983.2 & $* *<0,0001$ \\
72 horas & 2 & 363,751880 & 181,875940 & 258624 & $* *<0,0001$ \\
96 horas & 2 & 163,128245 & 81,564123 & 115983 & $* *<0,0001$ \\
& & & & & \\
\hline
\end{tabular}

Tabela 10. Análise de variância da tabela 8 com desdobramento do fator concentração

\begin{tabular}{lcccrc}
\hline FV & GL & SQ & QM & F & Pr $>$ F \\
& & & & & \\
\hline $0,0 \mathrm{mM}$ & 8 & 523,786595 & 65,473324 & 93101,8 & $* *<0,0001$ \\
$0,1 \mathrm{mM}$ & 8 & 474,348587 & 59,293573 & 84314,3 & $* *<0,0001$ \\
$0,2 \mathrm{mM}$ & 8 & 603,940394 & 75,492549 & 107349 & $* *<0,0001$ \\
\hline
\end{tabular}




\subsection{Atividade da SOD em PAGE não desnaturante}

Os resultados em PAGE (Figura 12) demonstraram ampla variação na atividade total das isoformas de SOD, relacionadas às concentrações e horários de exposição ao metal. No controle $(0 \mathrm{mM})$, duas isoformas de SOD foram identificadas com comportamento diferencial ao longo do período. Enquanto uma das isoformas, a mais eletronegativa, permanece evidente somente até $24 \mathrm{~h}$, a outra, menos eletronegativa, tem sua atividade reduzida após $48 \mathrm{~h}$ de crescimento da cultura.

$\mathrm{Na}$ concentração mais baixa de cádmio $(0,1 \mathrm{mM})$ foi observada a presença de três isoformas da enzima, duas delas correspondentes as duas isoenzimas observadas anteriormente no controle, e a terceira de posição intermediária a qual não foi observada no controle. Estas três isoenzimas foram observadas até $24 \mathrm{~h}$ de exposição ao metal, permanencendo apenas duas isoformas após este período, com a constante manutenção de uma baixa atividade após $72 \mathrm{~h}$.

$\mathrm{Na}$ concentração mais alta de cádmio $(0,2 \mathrm{mM})$, apenas duas isoformas, as mesmas observadas no controle, foram identificadas, porém, apresentando em geral baixos níveis de atividade, sendo possível apenas sua clara identificação nos períodos de $3 \mathrm{~h}, 12$ h, 24 h e 96 h, e também não apresentando um padrão definido de atividade ao longo do tempo de exposição das células ao metal. 

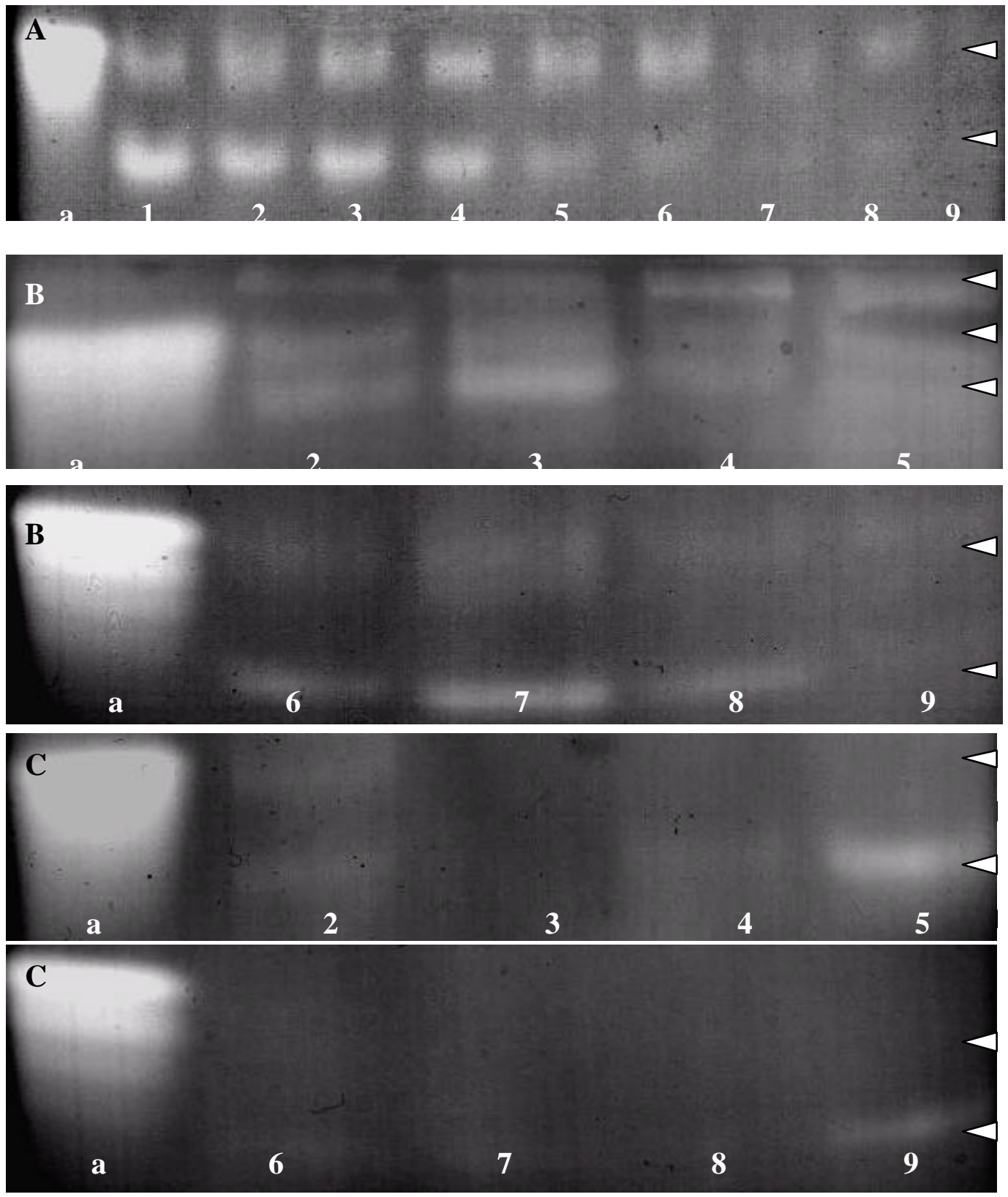

Figura 12- Atividade de SOD determinada em PAGE não desnaturante; (A) $0 \mathrm{mM}$, (B) 0,1 mM e (C) 0,2 mM de CdCb; (1) 0 h, (2) 3h, (3) $6 \mathrm{~h}$, (4) 12h, (5) 24 h, (6) 36 h, (7) 48 h, (8) 72 h e (9) 96 h; (a) padrão de SOD de fígado bovino. As setas representam as isoformas de SOD 


\subsection{Atividade da GR em espectrofotômetro e em PAGE não desnaturante}

A atividade da GR (Figura 13) de células de BY-2 apresentou variações significativas durante o período de exposição ao metal, na concentração $0,2 \mathrm{mM}$. Houve aumento da atividade da enzima logo no início (3 h), com declínio subsequente e novamente aumento a partir de 12 h., permanecendo até $36 \mathrm{~h}$. Na concentração mais baixa do metal $(0,1 \mathrm{mM})$ não foi observado aumento significativo.

A atividade em PAGE não desnaturante (Figura 14) demonstrou que embora a atividade das concentrações $0 \mathrm{mM}$ e $0,1 \mathrm{mM}$ de $\mathrm{CdCl}_{2}$ tenham sido baixas, mantiveram um nível basal de atividade, diferentemente do comportamento diferencial das outras enzimas já descritas (CAT e SOD). Observou-se também o comportamento diferencial de duas isoformas.

A análise estatística (Tabela 11), mostra que as concentrações (Conc), os períodos de tempo (Horas) e a interação entre estes fatores apresentaram pelo menos um valor diferindo da média ao nível de significância $1 \%$. A Tabela 12 mostra a mesma análise de variância, sendo possível observar que com exceção de 0 horas, todos os demais horários apresentam pelo menos um valor diferindo da média para as diferentes concentrações. Na Tabela 13, pode-se observar que todas as concentrações apresentam pelo menos um valor diferindo da média com relação aos tempos de exposição. 


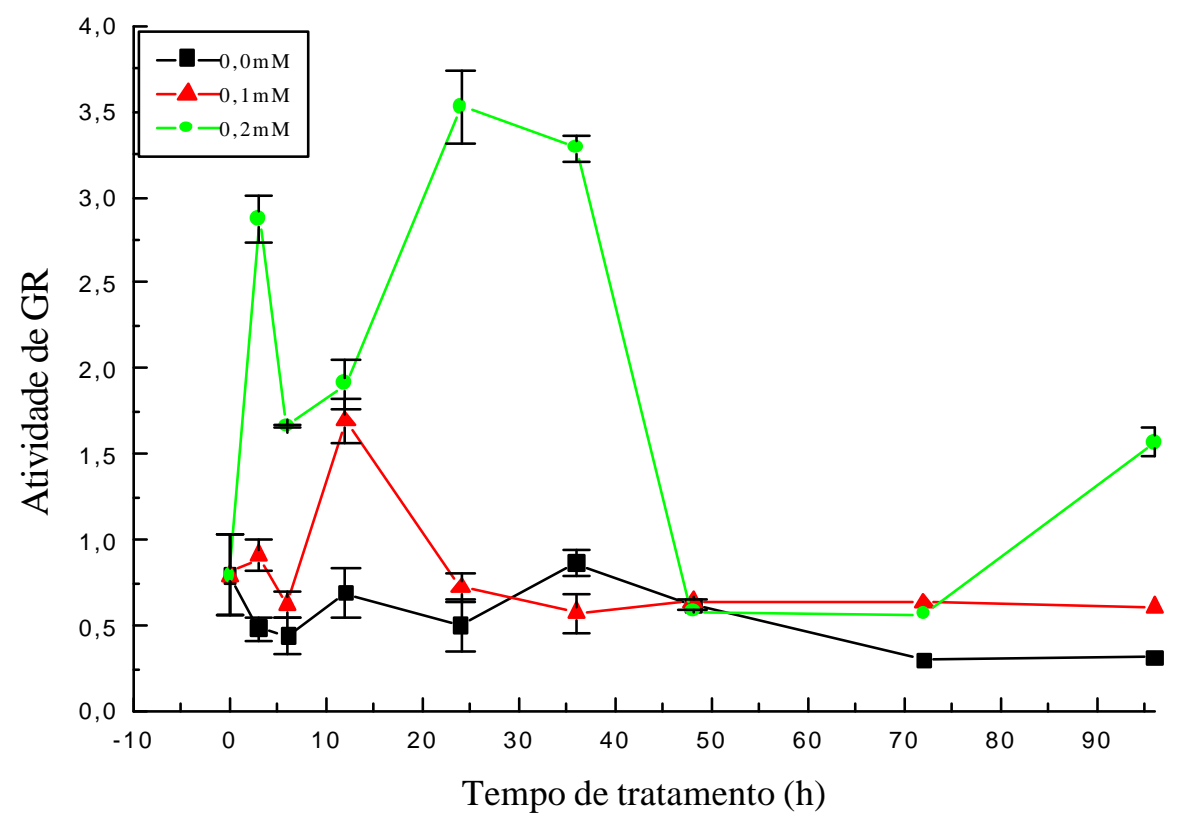

Figura 13- Atividade específica de GR ( $\mu \mathrm{mol} / \mathrm{min} / \mathrm{mg}$ prot) em células de BY-2 submetidas à diferentes concentrações de $\mathrm{CdCl}_{2}$ 

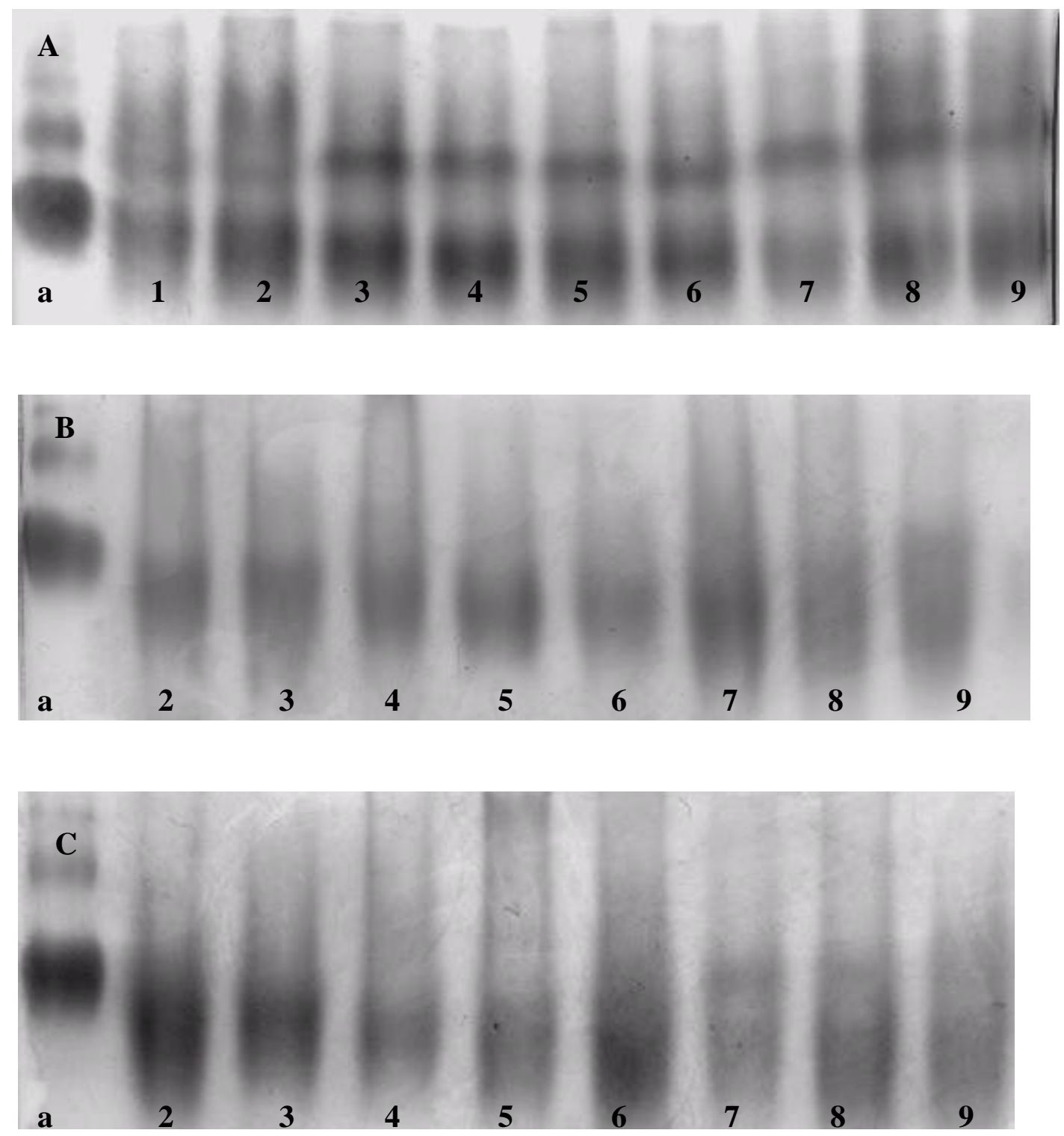

Figura 14- Atividade de GR determinada em PAGE não-denaturante em células de BY-2 submetidas à (A) $0 \mathrm{mM}$, (B) $0,1 \mathrm{mM}$ e (C) $0,2 \mathrm{mM}$ de $\mathrm{CdCb}$; (1) $0 \mathrm{~h}$, (2) 3 h, (3) 6 h, (4) 12 h, (5) 24 h, (6) 36 h, (7) 48 h, (8) 72 h e (9) 96 h; (a) padrão de GR 
Tabela 11. Análise de variância (The SAS System - The GLM Procedure) dos dados provenientes da atividade de GR em espectrofotômetro

\begin{tabular}{lcrlcl}
\hline FV & GL & SQ & QM & F & Pr $>$ F \\
\hline Conc & 2 & 18,73143356 & 9,36571678 & 7761171 & $* *<0,0001$ \\
Horas & 8 & 8,36841613 & 1,04605202 & 866841 & $* *<0,0001$ \\
Conc*Horas & 16 & 13,90779336 & 0,86923708 & 720318 & $* *<0,0001$
\end{tabular}

* 5\% de significância; ** $1 \%$ de significância $\quad \mathrm{CV}=0,102285$

Tabela 12. Análise de variância com desdobramento do fator horas

\begin{tabular}{lcclrl}
\hline FV & GL & SQ & QM & F & Pr $>$ F \\
\hline 0 horas & 2 & 0,000001408 & 0,000000704 & 0,58 & 0,5649 \\
3 horas & 2 & 6,470911 & 3,235455 & 2681153 & $* *<0,0001$ \\
6 horas & 2 & 1,767718 & 0,883859 & 732435 & $* *<0,0001$ \\
12 horas & 2 & 1,680511 & 0,840256 & 696302 & $* *<0,0001$ \\
24 horas & 2 & 11,500870 & 5,750435 & 4765264 & $* *<0,0001$ \\
36 horas & 2 & 8,921920 & 4,460960 & 3696703 & $* *<0,0001$ \\
48 horas & 2 & 0,004652 & 0,002326 & 1927.30 & $* *<0,0001$ \\
72 horas & 2 & 0,123288 & 0,061644 & 51083.2 & $* *<0,0001$ \\
96 horas & 2 & 1,720771 & 0,860385 & 712983 & $* *<0,0001$ \\
& & & & & \\
\hline
\end{tabular}

Tabela 13. Análise de variância com desdobramento do fator concentração

\begin{tabular}{lrrrrl}
\hline FV & GL & SQ & QM & \multicolumn{1}{l}{ F } & Pr $>$ F \\
\hline $0,0 \mathrm{mM}$ & 8 & 0,627925 & 0,078491 & 65043,5 & $* *<0,0001$ \\
$0,1 \mathrm{mM}$ & 8 & 1,927980 & 0,240997 & 199710 & $* *<0,0001$ \\
$0,2 \mathrm{mM}$ & 8 & 19,720305 & 2,465038 & 2042725 & $* *<0,0001$ \\
\hline
\end{tabular}




\subsection{Atividade da GST em espectrofotômetro}

A atividade da GST (Figura 15) em células BY-2 apresentou variações significativas tanto na concentração de $0,1 \mathrm{mM}$ como na concentração de $0,2 \mathrm{mM} \operatorname{logo}$ na fase inicial dos tratamentos $(12 \mathrm{~h})$, com aumento significativo da atividade de GST até 24 h, quando a atividade decaiu chegando a valores próximos ao do controle após 36 $\mathrm{h}$ de tratamento. Após este período, a atividade de GST permaneceu em níveis próximos a zero tanto no controle como no tratamento com $0,1 \mathrm{mM}$ de $\mathrm{CdCb}$, e em níveis mais elevados para a concentração de $0,2 \mathrm{mM}$.

A análise estatística (Tabela 14), mostra que as concentrações (Conc), os períodos de tempo (Horas) e a interação entre estes fatores apresentaram pelo menos um valor diferindo da média ao nível de significância $1 \%$. A Tabela 15 mostra a mesma análise de variância, sendo possível observar que com exceção de 0 horas, todos os demais horários apresentam pelo menos um valor diferindo da média para as diferentes concentrações. Na Tabela 16 pode-se observar que todas as concentrações apresentam pelo menos um valor diferindo da média com relação aos tempos de exposição. 


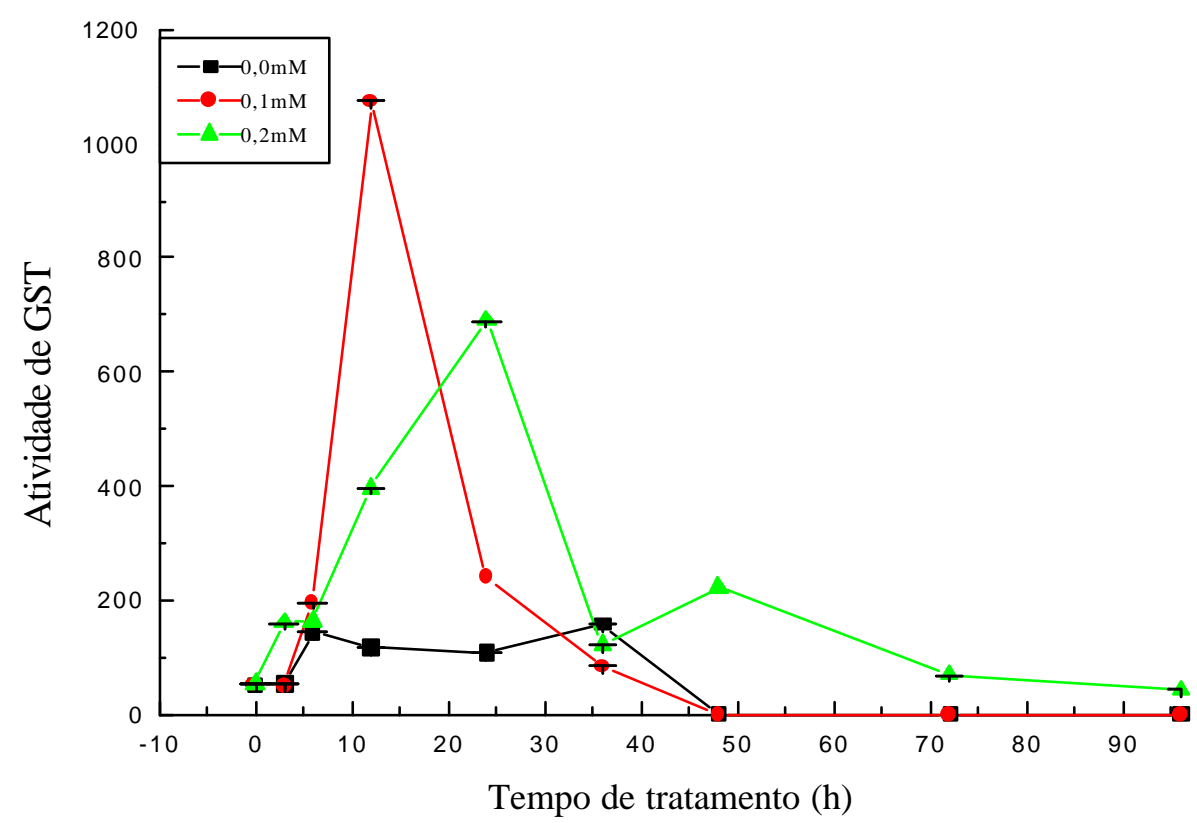

Figura 15- Atividade específica de GST ( $\mu \mathrm{mol} / \mathrm{min} / \mathrm{mg}$ prot) em células de BY-2 submetidas à diferentes concentrações de $\mathrm{CdCl}_{2}$ 
Tabela 14. Análise de variância (The SAS System - The GLM Procedure) dos dados provenientes da atividade de GST em espectrofotômetro

\begin{tabular}{lrrrrl}
\hline FV & GL & SQ & QM & F & Pr $>$ F \\
& & & & & \\
\hline Conc & 2 & 220846,794 & 110423,397 & 3879331 & $* *<0,0001$ \\
Horas & 8 & 1408595,790 & 176074,474 & 6185747 & $* *<0,0001$ \\
Conc*Horas & 16 & 1223876,401 & 76492,275 & 2687283 & $* *<0,0001$
\end{tabular}

* 5\% de significância; ** $1 \%$ de significância $\quad \mathrm{CV}=0,106562$

Tabela 15. Análise de variância com desdobramento do fator horas

\begin{tabular}{lrrrrr}
\hline FV & GL & SQ & \multicolumn{1}{c}{ QM } & F & Pr $>$ F \\
\hline 0 horas & 2 & 0,055505 & 0.027752 & 0,97 & 0,3901 \\
3 horas & 2 & 15247 & 7623.318200 & 267818 & $* *<0,0001$ \\
6 horas & 2 & 2966,871600 & 1483,435800 & 52115,2 & $* *<0,0001$ \\
12 horas & 2 & 967471 & 483736 & $1,699 \mathrm{E} 7$ & $* *<0,0001$ \\
24 horas & 2 & 370300 & 185150 & 6504591 & $* *<0,0001$ \\
36 horas & 2 & 5411,961033 & 2705,980517 & 95065,0 & $* *<0,0001$ \\
48 horas & 2 & 66791 & 33395 & 1173229 & $* *<0,0001$ \\
72 horas & 2 & 6707,140833 & 3353,570417 & 117816 & $* *<0,0001$ \\
96 horas & 2 & 2586,616033 & 1293,308017 & 45435.8 & $* *<0,0001$ \\
& & & & & \\
\hline
\end{tabular}

Tabela 16. Análise de variância com desdobramento do fator concentração

\begin{tabular}{lrrrrl}
\hline FV & GL & \multicolumn{1}{c}{ SQ } & QM & \multicolumn{1}{l}{ F } & Pr $>$ F \\
& & & & & \\
\hline $0,0 \mathrm{mM}$ & 8 & 64255 & 8031,866100 & 282171 & $* *<0,0001$ \\
$0,1 \mathrm{mM}$ & 8 & 1898015 & 237252 & 8334995 & $* *<0,0001$ \\
$0,2 \mathrm{mM}$ & 8 & 670203 & 83775 & 2943147 & $* *<0,0001$ \\
\hline
\end{tabular}




\subsection{Atividade de guaiacol peroxidase por espectrofotometria}

A análise de guaiacol peroxidase foi realizada pelo método espectrofotométrico. Os resultados dessa análise mostraram um aumento significativo de atividade da enzima tanto no controle como nos dois tratamentos após $24 \mathrm{~h}$, porém, os aumentos nos tratamentos com $\mathrm{CdCh}$ foram maiores, permanecendo com cerca de duas vezes a atividade do controle após $96 \mathrm{~h}$ de tratamento (Figura 16). Devido a não disponibilidade de material biológico em quantidade suficientes em todos os experimentos realizados, a análise estatística não foi conduzida, estando os dados apresentados apenas com os desvios padrões. 


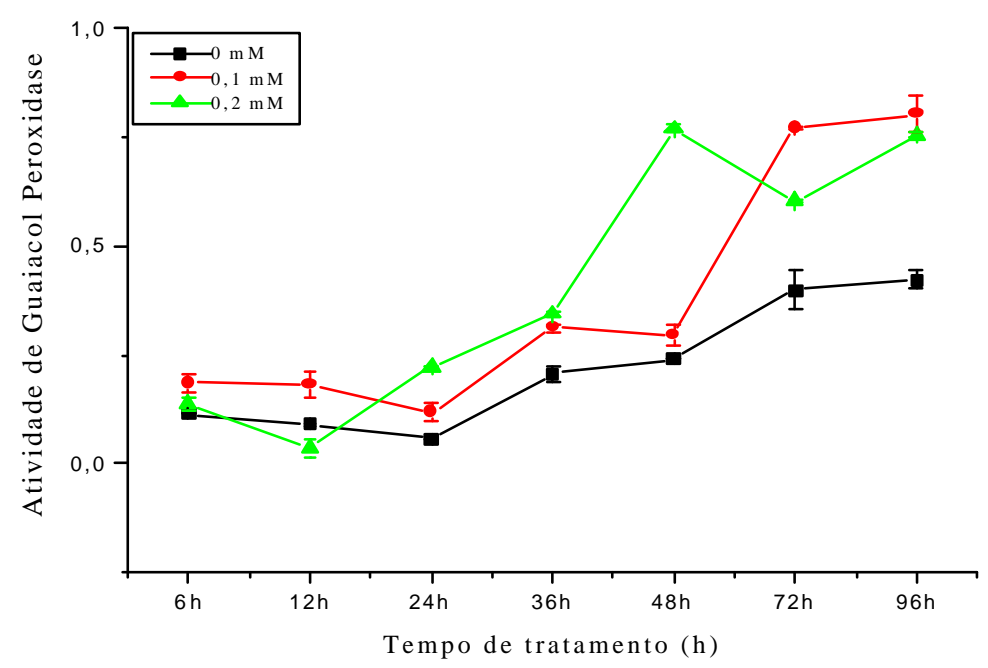

Figura 16- Atividade específica de guaiacol peroxidase $(\mu \mathrm{mol} / \mathrm{min} / \mathrm{mg}$ prot$)$ em células de $\mathrm{BY}-2$ submetidas à diferentes concentrações de $\mathrm{CdCb}$ 


\subsection{Peroxidação lipídica}

O ensaio para determinação de malonaldeído por espectrofotometria resultante de danos ocasionados na membrana celular pelas EAOS foi realizada para todos os tratamentos. Os resultados mostraram que as concentrações utilizadas de $\mathrm{CdCh}$, (0,1 mM e 0,2 mM) aparentemente não causaram peroxidação lipídica (Figura 17). Dessa forma, de acordo com os resultados das atividades enzimáticas, pode-se dizer que a resposta celular antioxidativa foi suficiente para evitar estes danos celulares.

De certa forma esta análise necessitará de novas repetições e testes para que dados mais precisos possam ser obtidos. 


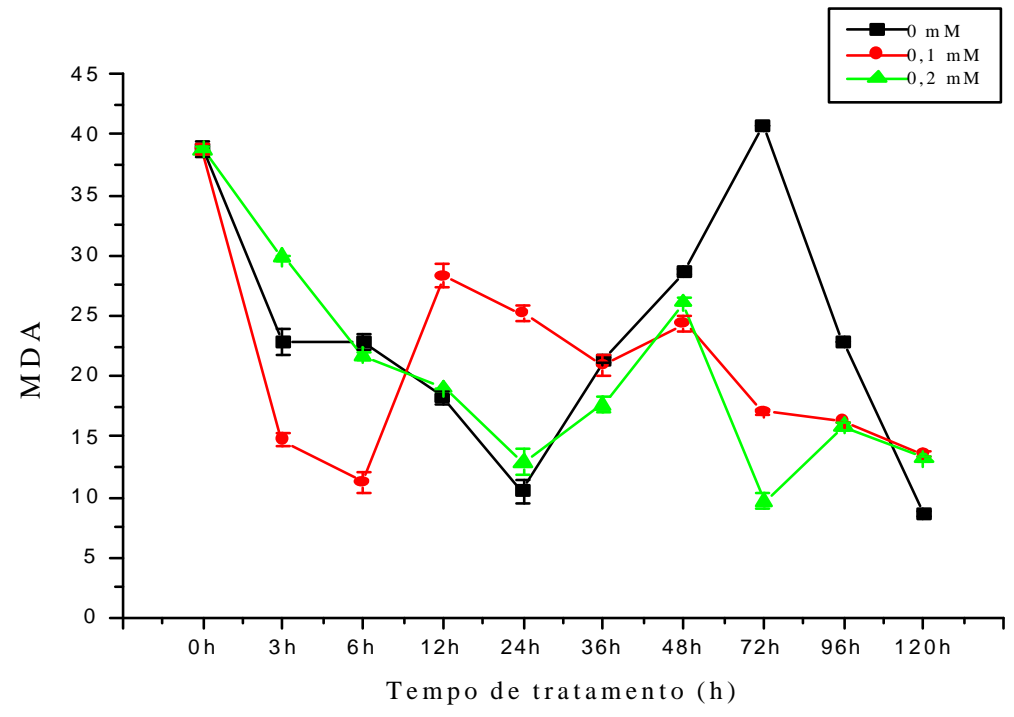

Figura 17- Quantidade de MDA (mmol/g tecido) em células de BY-2 submetidas ao $\mathrm{CdCl}_{2}$ 


\section{DISCUSSÃO}

Estudos com culturas celulares têm contribuído com informações valiosas sobre mecanismos envolvidos no metabolismo celular e sinais transducionais, regulação da expressão gênica, senescência e morte celular. Entretanto, torna-se importante salientar o comportamento diferencial das células nesta situação in vitro com relação aquelas in vivo. Uma das principais características é o estado de estresse oxidativo imposto por esta situação. A maioria das células in vivo estão expostas a baixas concentrações de $\mathrm{O}_{2}$, que correspondem a razão de $1-10 \mathrm{~mm} \mathrm{Hg}$, com algumas exceções. $\mathrm{Na}$ cultura celular, estima-se aproximadamente, $150 \mathrm{mmHg}$ de $\mathrm{O}_{2}$. Assim, pode-se dizer que há mais EAOs sendo produzidas em células in vitro (Dey \& Kar, 1995). Além disso, as células sobreviventes ao estresse podem se reestabelecerem e crescerem utilizando sinais transducionais dependentes de EAOs, o que raramente ocorre in vivo (Halliwell, 2003).

A primeira vista, pode parecer surpreendente como o $\mathrm{Cd}$, que não é um metal de transição, possa causar estresse oxidativo. Entretanto, o Cd liga-se aos grupos tióis das enzimas, como GR por exemplo (Creissem \& Mullineaux, 1995). O mesmo mecanismo de inibição pode ser possível também para APX (Chen \& Asada, 1989, 1992).

$\mathrm{O} \mathrm{Cd}$, em contraste com outros metais pesados, não parece agir diretamente na produção de ROS, via Fenton e/ou reações Haber Weiss (DiToppi \& Gabrielli, 1999), porém o Cd reage com ligantes N e S. Entretanto, os mecanismos moleculares para a toxicidade são pouco conhecidos

As alterações no crescimento nas células BY-2 expostas a concentração de $0,5 \mathrm{mM}$ observadas neste trabalho, estão de acordo com a extensa literatura 
relacionada ao estresse por metais pesados, incluindo $\mathrm{Cd}$, ou seja, nesta dose maior, há um efeito deletério do $\mathrm{Cd}$ sobre o metabolismo celular com progressiva inibição do crescimento e viabilidade celular. É , ainda, bem conhecido que o $\mathrm{Cd}$ inibe crescimento (Godbold \& Huttermann, 1985; Arduini et al., 1996; Arisi et al., 2000). Efeitos drásticos induzidos pela toxicidade do $\mathrm{Cd}$ têm sido relatados em organismos vivos de forma geral (Vitória et al., 2001). Em plantas, a toxicidade desse metal pode promover diversas alterações no metabolismo, as quais são principalmente resultado da ação de EAOs cuja geração é intensificada sob condições de estresse (Smirnoff, 1993; Prasad, 1995).

Curiosamente, dentre os resultados obtidos do presente trabalho observou-se estímulo de crescimento na concentração de $0,1 \mathrm{mM}$ de $\mathrm{Cd}$. A viabilidade neste caso também foi relativamente alta para células na condição de estresse por este metal pesado, de acordo com relatos prévios na literatura (Kanji et al., 1995). Resultados semelhantes foram encontrados em Aspergillus nidulans, onde concentrações baixas de $\mathrm{CdCl}_{2}$ estimularam o crescimento enquanto o acúmulo e concentrações maiores do metal resultaram em uma drástica redução do crescimento até a morte celular Cooley et al., 1986, Guelfi, 2001).

Além disso, diversos bioensaios com culturas in vitro têm demonstrado respostas relativamente distintas com diferentes propósitos experimentais comparadas a plantas. Culturas in vitro de cana-de-açúcar, por exemplo, submetidas crescimento na presença deste metal em baixas concentrações, também apresentaram a indução do crescimento de maneira similar ao observado em A. nidulans (Fornazier et al., 2002b).

Entretanto, torna-se necessário uma avaliação complementar para a comprovação deste resultado, evidenciando rotas metabólicas e eventual complexação com componentes do meio de cultura. Sabe-se que a absorção, distribuição e feitos do $\mathrm{Cd}$ em diferentes processos metabólicos parecem ser controlados por diversos fatores na planta, tal como espécies e/ou variedades, água e estado nutricional (Melo et al., 1997). Espécies de plantas e também genótipos da mesma espécie, diferem amplamente em sua habilidade para absosrver e transportar esses metais dentro da planta (Petterson, 1977; Gabrielli et al., 1990; Rebafka et al., 1990; Lubben \& Sauerbeck, 1991; Sandalio et al., 2001; Olmos et al., 2003). Fatores, como estágio de crescimento e tempo de exposição 
ao metal, também, afetam a absorção e distribuição de $\mathrm{Cd}$ entre diferentes partes da planta (Melo et al., 1997; Vranová et al., 2002; Alscher et al., 2002, Fojtová et al., 2002; Schützendubel \& Polle, 2002).

Em células BY-2, os resultados demonstraram variação no padrão aminoacídico, com aumento de alguns aminoácidos e diminuição de outros. A diminuição de alguns padrões pode indicar queda no metabolismo, enquanto o aumento da composição aminoacídica observada principalmente na concentração de $0,2 \mathrm{mM}$ pode indicar complexação a metais.

Vários mecanismos são utilizados pelas plantas para a desintoxicação de EAOs, sendo importante estabelecer se a exposição de plantas ao Cd causa um efeito prejudicial ou estimulatório das enzimas envolvidas nos processos de desintoxicação.

Em baixas concentrações, as EAOs induzem genes de defesa e respostas adaptativas, e em altas concentrações, a morte celular é iniciada. Recentemente, informações sobre o papel das EAOs têm sugerido que estas não são apenas moléculas sinalizadoras de estresse mas também sinais intrínsecos regulatórios do crescimento e desenvolvimento da planta (Vranová et al., 2002).

$\mathrm{O}$ tratamento com $\mathrm{Cd}$ afeta as atividades das enzimas antioxidantes, mas resultados contrastantes têm sido relatados. Por exemplo, em folhas de Helianthus annus, as atividades das enzimas relacionadas ao ciclo glutationa-ascorbato foram decrescentes (Gallego et al., 1996). Raízes e folhas de Phaseolus vulgaris e cultura de células de Nicotiana tabacum, apresentaram atividades elevadas de APX após exposição ao Cd (Chaoui et al., 1997). Em plântulas de Phaseolus aureus, o Cd induziu aumento na atividade de GPX, mas diminuiu a atividade de CAT (Shaw, 1995). O Cd também induziu a peroxidação lipídica, sugerindo a indução de um estresse oxidativo (Shaw, 1995; Gallego et al., 1996; Lozano-Rodriguez et al., 1997 e Chaoui et al., 1997).

A funcionalidade das proteínas pode ser afetada pelas EAOs tanto por oxidação das cadeias laterais dos aminoácidos como por reações secundárias com produtos aldeídicos da peroxidação lipídica (Reinheckel et al., 1998; Sandalio et al., 2001). Tanto reações primárias como secundárias, podem introduzir grupos carbonil em proteínas, demonstrado por exemplo em extratos foliares de ervilha (Sandalio et al., 
2001). É possível que as mudanças observadas em sistemas antioxidantes ocorram como um resultado de processos de degradação celular não específicos.

A CAT é encontrada no citoplasma, mitocôndrias e peroxissomos de células de animais, vegetais e microrganismos aeróbicos, atuando como reguladoras dos níveis de $\mathrm{H}_{2} \mathrm{O}_{2}$, os quais são decompostos em $\mathrm{H}_{2} \mathrm{O}$ e $\mathrm{O}_{2}$ (Scandalios, 1990), além de serem abundantes em glioxissomas de tecidos que armazenam lipídeos, onde decompõem o $\mathrm{H}_{2} \mathrm{O}_{2}$ formado durante a $\beta$-oxidação de ácidos graxos (Holtman et al., 1994; Voet \& Voet, 1995), e em peroxissomas de folhas verdes, onde o $\mathrm{H}_{2} \mathrm{O}_{2}$ é produzido durante a fotorrespiração pela conversão do glicolato em glioxilato (Willekens et al., 1997). Em células BY-2, a diminuição da atividade de CAT na concentração mais elevada $(0,2 \mathrm{mM})$ durante o período inicial de exposição ao metal está de acordo com os resultados obtidos em feijão (Chaoui, 1997), ervilha (Dalurzo et al., 1997), Lupinus luteus (Gowdz et al., 1997) e girassol (Galego et al., 1999). Já na concentração menor $(0,1 \mathrm{mM})$ a atividade de CAT não sofreu alteração significativa em relação ao controle no perído inicial de exposição ao metal. Considerando que a CAT é diretamente regulada pelos níveis de $\mathrm{H}_{2} \mathrm{O}_{2}$ (Polidoros \& Scandalios, 1999), a atividade inalterada desta enzima na concentração menor $(0,1 \mathrm{mM})$, sugere que pelo menos no período analisado não houveram alterações significativas no processo de geração de $\mathrm{H}_{2} \mathrm{O}_{2}$, ou que outro sistema enzimático esteja relacionado, como a GPX por exemplo.

Entretanto, outra possibilidade é que sejam acionados outros mecanismos de defesa comuns, como aqueles envolvidos com outros tipos de estresses ambientais bióticos e abióticos. O importante é que o ponto de ligação entre estes sistemas é o acúmulo de $\mathrm{H}_{2} \mathrm{O}_{2}$, que age como uma molécula sinalizadora.

Esses resultados podem indicar resposta dose dependente e que em altas doses a capacidade das enzimas antioxidantes é diminuída (Gowdz et al., 1997), contrastantes com aqueles obtidos em rabanete, com aumento da CAT desde as primeiras horas de tratamento sob altas concentrações de $\mathrm{CdCh}_{2}$ (Vitória et al., 2001).

As plantas sob condições de estresse exibem um padrão de resposta característico à estas situações conhecido como Síndrome de Adaptação Geral (GAS), que poderia estar relacionada a queda inicial observada para atividade de alguns 
sistemas enzimáticos, como ocorreu para CAT. A GAS é dividida em quatro fases: (1) Fase de Resposta, representada pelo início do estresse, caracterizando uma reação de alarme que compreende um declínio da vitalidade; (2) Fase de Restituição, onde há a permanência do estresse, conferindo um estágio de resistência através de processos de adaptação, reparos e endurecimento; (3) Fase Final, onde um longo período de exposição ao estresse caracteriza um estágio de exaustão, que supera a capacidade de adaptação e induz doenças crônicas ou até mesmo a morte; (4) Fase de Regeneração, com a regeneração total ou parcial das funções fisiológicas, após a retirada do estresse (Lichtenthaler, 1996; Leshem et al., 1998).

De acordo com Erdei et al, (1998), o estressor pode causar modificações e dessincronizações das oscilações dos processos fisiológicos e bioquímicos correspondentes a fase de resposta. A fase de restituição ou aclimatação corresponde a fixação de diferentes processos bioquímicos e fisiológicos, correspondentes as novas condições, assegurando a máxima resistência do organismo.

Segundo a GAS, os peptídeos ligados à metais (MBPs), PCs e mecanismos de bombas transportadoras de íons das membranas são os mecanismos de maior importância na desintoxicação das plantas submetidas à altas concentrações de metais pesados (Leshem et al., 1998).

Em células BY-2 o aumento da CAT nas concentrações de 0,1 e 0,2 mM no período final de exposição ao metal pode estar associado a uma intensificação dos níveis de $\mathrm{H}_{2} \mathrm{O}_{2}$ a serem convertidos por essa enzima. Nesse período a eficiência do ciclo da glutationa-ascorbato pode ter sido menor, e segundo Creissen et al. (1993), essa via é principalmente ativa em cloroplastos. Também pode ter ocorrido uma provável depleção de GSH para síntese de PCs, tornando a célula mais susceptível ao estresse oxidativo sob exposição ao Cd (Jackson et al., 1992; Meuwly \& Rauser, 1992) e a geração de $\mathrm{H}_{2} \mathrm{O}_{2}$ nos glioxissomos. Assim é sugerido que o $\mathrm{H}_{2} \mathrm{O}_{2}$ gerado deve ser metabolizado principalmente pela CAT, ocasionando o seu aumento.

As SODs são enzimas que contém metais ligados a sua estrutura e catalisam a dismutação do radical superóxido em $\mathrm{O}_{2}$ e $\mathrm{H}_{2} \mathrm{O}_{2}$ (Mattson, 1998), regulando assim, os níveis de $\mathrm{O}_{2}^{\bullet}$ e $\mathrm{H}_{2} \mathrm{O}_{2}$ que são substratos da reação que origina os radicais $\mathrm{OH}^{\bullet}$, 
representando por isso, o papel central no mecanismo de defesa antioxidante (Alscher et al., 1998; 2002).

Em plantas existem três formas desta enzima, as quais são classificadas segundo o íon metálico em seu sítio ativo: formas cobre/zinco ( $\mathrm{Cu} / \mathrm{Zn}-\mathrm{SOD})$, manganês (Mn-SOD) e ferro (Fe-SOD) (Bowler et al., 1994; Chen \& Liu, 1996).

O padrão de atividade da SOD em células BY-2 sofreu alterações significativas com relação as isoformas nas concentrações de $\mathrm{CdCb}$ utilizadas, indicando que houve provavelmente indução e inibição diferencial, sendo observada variação específica apenas para uma das isoformas, ausente no controle e na concentração de 0,2 mM. A atividade da SOD, bem como a expressão dos genes que codificam suas isoformas têm mostrado sofrer alterações sob diversas condições de estresse (Willekens et al., 1995). Esta alteração no padrão de atividade dessa enzima é bastante variável e pode ser dependente da espécie, tecido, fases de desenvolvimento da planta além das próprias particularidades das isoformas (Azevedo et al., 1998). Além disso, a indução de três isoformas na concentração $0,1 \mathrm{mM}$ do metal, diferentemente das duas observadas na concentração mais alta, pode estar relacionada a alta atividade da CAT neste período inicial contra $\mathrm{o}_{2} \mathrm{O}_{2}$ eventualmente produzido pela isoforma adicional de SOD. Embora no controle seja observada uma atividade ainda maior da CAT, temos que considerar que nos tratamentos o metal pode estar perturbando diversos processos metabólicos que também induzem ao estresse oxidativo, além da participação de outras peroxidases. Há evidências que suportam a existência em plantas de uma NADPH oxidase de membrana plasmática envolvida na produção de superóxido, que é convertido a $\mathrm{H}_{2} \mathrm{O}_{2}$ por SOD durante a rápida produção de EAOs (Keller et al., 1998; Torres et al., 1998).

Como já citado, foram encontradas três isoformas, evidenciadas apenas na concentração mais baixa. Esse resultado é compatível a literatura, que relata diferentes isoformas, sendo que foi observada a presença de sete isoformas em milho (Giannopolitis \& Ries, 1977) e pelo menos sete isoformas em cana-de-açúcar (Fornazier et al., 2002). Resultados similares foram observados em Lupinus luteus (Gowzdz et al., 1997) e Helianthus annus (Gallego et al., 1999) também em altas concentrações. Pereira 
et al., (2003) observou a presença de várias isoformas, inclusive variação destas nas diferentes espécies de crotalária.

A glutationa apresenta muitas funções no metabolismo de plantas. Está envolvida na desintoxicação de metais pesados e xenobióticos e tem papel na ativação gênica e na proteção de estresse oxidativo (Noctor \& Foyer, 1998; Schutzendubel et al., 2001). Como antioxidantes, a glutationa, o ascorbato e enzimas como SOD, APX e CAT controlam as concentrações celulares de $\mathrm{H}_{2} \mathrm{O}_{2} \mathrm{e} \mathrm{O}_{2}^{-}$. A reciclagem de ascorbato e GSH é realizada pela monodehidroascorbato redutase (MDAR), dehidroascorbato redutase (DAR) e glutationa redutase (GR) (Schutzendubel et al., 2001).

A GR é a enzima chave do ciclo ascorbato-glutationa. Baixos níveis de $\mathrm{Cd}$ produziram aumento da atividade de GR em Alyssum argenteum, considerada como uma planta hiperacumuladora, enquanto esta atividade foi reduzida em concentrações altas de Cd (Schiuckler \& Caspi, 1999). Vários papéis metabólicos, regulatórios e antioxidativos da GSH, resultam de sua oxidação a GSSG. Para a maioria dessas funções a GSH deve estar em sua forma reduzida, conduzida pela flavoproteína glutationa redutase (GR) em uma reação de oxidação-redução NADPH-dependente da GSSG para GSH (Creissen et al., 1994a).

Em folhas de ervilhas os cloroplastos e mitocôndrias apresentaram $77 \%$ e $3 \%$, respectivamente, do total de atividade da GR, com o restante sendo citosólico (Edwards et al., 1990). A GSH tem uma afinidade alta para ligação ao Cd fazendo deste composto um quelante potencial no citosol (Beck et al, 2003). Evidências sugerem que GSH constitui uma primeira e rápida resposta de defesa contra exposição ao $\mathrm{Cd}$ e que a tolerância para sustentar a exposição depende da síntese de PCs em plantas (Singhal et al., 1987). Finalmente Grill et al. (1989) mostrou que as PCs são sintetizadas a partir de GSH.

Assim, manter os níveis altos de GSH constitui uma estratégia importante para a síntese de PCs, sendo que para isso, um aumento na atividade da GR se torna necessário (Cunningham et al., 1995; Leopold et al., 1999; Cobbett, 2000; Mejáre \& Bülow, 2001; Cobbett \& Goldsbrough, 2002; Beck et al., 2003). Resultados similares foram encontrados em folhas de feijão (Chaoui et al., 1997), girassol (Gallego et al., 
1996), pimenta (Jemal et al., 1998), tabaco cv BY-2 (de Pinto et al., 2002), cana-deaçúcar (Fornazier et al., 2002), crotalária (Pereira et al., 2003), soja (Ferreira et. al., 2002), rabanete (Vitória et al. 2002).

O aumento da atividade da GR em células BY-2 na concentração de 0,2 $\mathrm{mM}$, provavelmente ocorreu para manter altos níveis de GSH. Este aumento ocorreu logo no início da exposição ao metal com depleção significante de glutationa oxidada inicialmente observada. Esta é uma resposta comum ao $\mathrm{Cd}$, com consumo de glutationa para a produção de fitoquelatina (Meuwly \& Rauser, 1992; Schneider \& Bergmann, 1995; Noctor et al., 1998; Xiang \& Oliver, 1998).

Embora o Cd seja o mais efetivo indutor na síntese de fitoquelatinas em plantas superiores, observoutse na alga marinha Dunaliella tertolecta maior indução de PCs por zinco (Tsuji et al., 2003). Apesar do aumento na atividade de GR representar um forte indício da consequente síntese de PCs, é necessário a identificação da presença destas e de complexos GSH-Cd ${ }^{2+}$ para confirmar a hipótese proposta. Além disso, o tripeptídeo GSH é um dos principais antioxidantes solúveis em plantas (Alscher, 1989) podendo estar atuando diretamente no $\mathrm{H}_{2} \mathrm{O}_{2}$.

A GST catalisa a conjugação da glutationa a diversos substratos eletrofílicos, fazendo parte de complexo sistema de desintoxicação de xenobióticos e radicais de oxigênio em plantas e animais (Daniel, 1993; Dixon, et al., 2002). O sistema de desintoxicação tem três funções: reconhecimento, compartimentalização e metabolismo de compostos citotóxicos. Este sistema completo inclui o citocromo P450 que oxida os compostos tóxicos, as GSTs e glucosiltransferases que conjugam as moléculas tóxicas de glutationa (GSH), podendo ser transportada para o vacúolo e metabolizada como um composto não tóxico (Marrs, 1996). A atividade de desintoxicação das GSTs também têm sido relacionadas ao ataque de patógenos, estresse oxidativo e por metais pesados, e processos metabólicos secundários (Seppänen et al., 2000).

Os resultados obtidos sugerem que houve balanço na utilização de GSH pelas enzimas antioxidantes do ciclo ascorbato-glutationa, ou seja, GR e GST. Na concentração de $0,1 \mathrm{mM}$ de $\mathrm{CdCh}$, provavelmente ocorreu predominância na utilização 
de GSH pela GST, diferente da concentração de $0,2 \mathrm{mM}$, provavelmente relacionada a utilização de GSH para produção de fitoquelatinas.

A GSH é um antioxidante bem conhecido com papel proeminente na defesa contra radicais livres em plantas. A síntese de fitoquelatinas induzida por Cd está associada a rápida depleção do total de GSH implicando em uma minimização da defesa contra radicais livres, que pode aumentar a peroxidação lipídica e perda da viabilidade celular. A tolerância a metais pesados de plantas está relacionada a sua habilidade de prevenir a depleção excessiva de GSH antes da função protetora PCs (Gallego et al., 1996; Jemal et al., 2000). A geração de $\mathrm{H}_{2} \mathrm{O}_{2}$ aumenta os níveis de GSH em plantas e cultura de células (Smith et al., 1985).

A glutationa reage quimicamente com EAOs, enquanto enzimas catalisam reações ligando $\mathrm{GSH}$ a desintoxicação de $\mathrm{H}_{2} \mathrm{O}_{2}$ no ciclo ascorbato-glutationa. A GSH protege proteínas contra desnaturação que causam oxidação de grupos tióis proteicos durante o estresse. Todas estas funções envolvem a oxidação de grupos tióis, principalmente para formar GSSG. Níveis celulares de GSH:GSSG são mantidos pela glutationa redutase (Noctor et al., 2002). A glutationa além de precursora para fitoquelatinas (Mejáre \& Bülow, 2001; Cobbett \& Goldsbrough, 2002; Beck et al., 2003) é substrato para as GSTs sendo utilizadas para reduzir peróxidos (Cummins et al., 1999).

As peroxidases são importantes enzimas das plantas, envolvidas em diversas reações como ligações de polissacarídeos, oxidação do ácido indol-acético, ligações de monômeros, lignificação, cicatrização de ferimentos, oxidação de fenóis, defesa de patógenos, regulação da elongação de células, entre outras. As plantas contém um número relativamente elevado de isoenzimas de peroxidases, principalmente localizadas nas paredes celulares, as peroxidases aniônicas (Campos \& Silveira, 2003). Entretanto, peroxidases de parede celular não implicam na produção de $\mathrm{H}_{2} \mathrm{O}_{2}$ em células de BY-2 tratadas com Cd (Olmos et al., 2003).

As peroxidases catalisam a oxidação do substrato utilizando o poder oxidante de $\mathrm{H}_{2} \mathrm{O}_{2}$, ou de peróxidos orgânicos. As isoenzimas diferem em sua capacidade por distintos substratos. Entretanto, o balanço das isoenzimas presentes na parede é muito importante, do ponto de vista da mesma, o crescimento diminui e, em 
contrapartida, aumenta a resistência mecânica e química em condições de estresse (Flurkey \& Jen, 1978; Gaspar et al., 1982; Musacchi, 1994; Campos \& Silveira, 2003). Nas interações planta-patógeno, o $\mathrm{H}_{2} \mathrm{O}_{2}$ induz uma sequência de reações envolvendo a ativação de peroxidases, o estímulo do metabolismo secundário, deposição de lignina e eventualmente morte celular (Alvarez \& Lamb, 1997).

De acordo com o observado para uma das peroxidases analisadas, a GPX, os resultados foram bastante evidentes no aumento da atividade desta enzima em ambas as concentrações utilizadas, $0,1 \mathrm{mM}$ e $0,2 \mathrm{mM}$ de $\mathrm{CdCl}$, que podem estar relacionados a grande disponibilidade de $\mathrm{H}_{2} \mathrm{O}_{2}$ produzidos pelo estresse principalmente nos períodos finais de exposição. Dessa forma, tanto CAT quanto GPX estariam agindo para ocasionar a depleção do peróxido.

Ambos, glutationa e $\mathrm{H}_{2} \mathrm{O}_{2}$ apresentam um papel na sinalização para a regulação de enzimas de estresse (May et al., 1998 e Noctor e Foyer, 1998). O $\mathrm{H}_{2} \mathrm{O}_{2}$ é o sinal sistêmico para a indução de APX (Karpinnski et al., 1999) Em cultura de calos de arroz (Oryza sativa) $\mathrm{H}_{2} \mathrm{O}_{2}$ transientemente induziu a síntese de mRNA para a APX citosólica (Morita et al., 1999). Em plântulas de pinheiro, o acúmulo de $\mathrm{H}_{2} \mathrm{O}_{2}$ dentro de poucas horas foi seguido por significante aumento de APX e CAT (Schutzendubel et al., 2001).

Além do estresse induzido, vários sistemas enzimáticos também podem levar a produção de $\mathrm{H}_{2} \mathrm{O}_{2}$ na superfície de células vegetais, incluindo peroxidases (Bolwell et al., 2003) e poliaminas oxidases (Angelini \& Federico, 1989). A evidência provém de trabalhos que indicam que o $\mathrm{H}_{2} \mathrm{O}_{2}$ produzido em células tratadas com $\mathrm{Cd}$ parecem ser eventos regulados, indicando calmodulina e fosforilação de proteínas como possíveis integrantes envolvidos no processo de ativação. Esta hipótese tem sido recentemente confirmada por Suzuki et al., (2001) durante o screening de genes de resposta ao Cd em Arabidopsis. Análises de sequenciamento mostraram que 1/3 dos genes identificados codificavam fatores de tradução incluindo três proteínas quinases, quatro fatores transcricionais e duas proteínas relacionadas a calmodulina. Isto sugere que a célula vegetal responde rapidamente ao $\mathrm{Cd}$ através da ativação de sinais 
específicos de tradução que podem incluir uma cascata de fosforilação proteica (Olmos et al., 2003).

Os peroxissomas também têm a capacidade de produzir, que poderia ser difundido para fora desta organela produzindo danos a diferentes compartimentos celulares, no entanto é metabolizado pela CAT. Os cloroplastos têm sido considerados os principais responsáveis para o estresse oxidativo produzido pelo $\mathrm{Cd}$. Entretanto, os resultados apresentados indicam que os peroxissomas poderiam ser uma fonte secundária de $\mathrm{H}_{2} \mathrm{O}_{2}$ mediador do estresse oxidativo (Romero-Puertas et al., 1999). A indução de atividade de algumas enzimas do ciclo ascorbato-glutationa, como GR, assim como NADP-dehidrogenases em resposta ao $\mathrm{Cd}$, sugerem que este sistemas enzimáticos podem ser importantes na defesa de células contra estresse oxidativo gerado pelo $\mathrm{Cd}$. Igualmente, estas enzimas antioxidantes parecem ser uma excelente escolha para o "design" genético molecular de estratégias direcionadas a melhorar a tolerância de plantas contra metais pesados.

Existe ainda a correlação entre os sistemas antioxidantes e a atividade mitótica em células BY-2. O nível de ascorbato e GR transitoriamente aumentam durante o segundo dia de crescimento da cultura, quando as células também têm seu máximo índice mitótico. No mesmo período de crescimento de BY-2, a expressão de dois genes para as fases $\mathrm{S}$ e $\mathrm{M}$ também transitoriamnete aumentam. Sabe-se por exemplo que ascorbato é requerido para a divisão celular e promove a progressão do ciclo celular de células competentes (Kerk et al., 1995; Kato \& Esaka, 1999; de Pinto et al., 2002).

A peroxidação da membrana celular afeta severamente sua funcionalidade tanto por oxidação de aminoácidos e integridade e pode produzir danos irreversíveis a funções celulares (Halliwell \& Gutteridge, 1989). A indução de danos na membrana celular está relacionada com peroxidação lipídica causada principalmente por radicais livres. Estes radicais juntamente com o $\mathrm{H}_{2} \mathrm{O}_{2}$ são as maiores fontes de EAOs. $\mathrm{O} \mathrm{HO}_{2}$ acumula-se em tecidos de plantas onde a atividade de antioxidantes como peroxidases, CATs e SODs esteja suprimida (Scandalios, 1994). 
Foi verificado que em plântulas de Amaranthus lividus o decréscimo na atividade de SOD na presença de cádmio, favorece o acúmulo do radical superóxido, que contribui para o dano na membrana. O decréscimo na atividade de POX e CAT pode ser uma das causas do acúmulo de $\mathrm{H}_{2} \mathrm{O}_{2}$ sobre estresse induzido por cádmio. Embora a atividade diminuída de SOD minimize a geração de $\mathrm{H}_{2} \mathrm{O}_{2}$ a partir do superóxido, o decréscimo simultâneo na atividade de SOD e CAT poderia ser uma explicação plausível para o acúmulo de $\mathrm{H}_{2} \mathrm{O}_{2}$ (Bhattacharjee, 1998). Pode dizer que o estresse induzido por $\mathrm{Cd}$ pode resultar na perda da semipermeabilidade natural de membranas celulares, dependente da magnitude da dose do metal pesado (Sung, 1995; Bhattacharjee, 1998).

Os resultados preliminares obtidos sugerem que em células de BY-2 provavelmente não houve um estresse oxidativo que conduzisse a peroxidação lipídica, em função do eficiente sistema enzimático envolvido. A atividade de $\mathrm{H}^{+}$-ATPase em girassol e trigo foi reduzida na presença de $\mathrm{Cd}$ e esta mudança poderia estar relacionada a modificações na constituição da membrana (Fodor et al., 1995). Entretanto, em ervilhas a deficiência em $\mathrm{H}^{+}$-ATPase não foi associada com aumento do acúmulo de $\mathrm{Cd}$ na raiz (Cohen et al., 1998).

O Cd produz aumento nas reações de substratos com ácido 2tiobarbitúrico (TBA) em folhas de ervilhas, com indício de peroxidação lipídica, e portanto de estresse oxidativo (Romero-Puertas et al., 1999; Sandalio et al., 2001; Berger et al., 2001.). Aumentos similares de TBA por exposição ao Cd foi observado em Phaseolus vulgaris (Somashekaraiah et al., 1992; Shaw, 1995; Chaoui et al., 1997), Helianthus annuus (Gallego et al., 1996), Pisum sativum (Lozano-Rodriguez et al., 1997) e por cobre e zinco em Fusarium equiseti e Fusarium acuminatum (Kayali \& Tarhan, 2003). 


\section{CONCLUSÕES}

1 - Foi observado inibição no crescimento das células submetidas a concentração de 0,5 $\mathrm{mM}$ de $\mathrm{CdCl}$;

2- Baixas concentrações de Cd estimularam o crescimento celular;

3- Nestas células, o mecanismo central envolvido na minimização dos danos causados pelo metal oscila entre os períodos de exposição utilizados;

4- No início da exposição, enzimas pertencentes ao ciclo ascorbato-glutationa, como a GR e GST provavelmente são as mais ativas;

5- No final da exposição, foram observados aumento das atividades de GPX e CAT em ambas as concentrações de $\mathrm{Cd}$, atuando diretamente no peróxido de hidrogênio;

6- Embora preliminares, os testes de peroxidação lipídica serviram para elucidar que no caso destas células e das concentrações do metal utilizadas, o sistema enzimático antioxidante foi capaz de evitar danos celulares provocados por estresse oxidativo. 


\subsection{Considerações Finais}

Em função dos resultados encontrados, sugere-se a complementação deste trabalho, com novos estudos que possam abranger outras enzimas envolvidas no ciclo ascorbato-glutationa, além de peptídeos de complexação de metais, como as fitoquelatinas.

A disponibilidade de "microarray" poderá permitir que enzimas antioxidantes possam ter seus genes codificadores estudados para nível de expressão em resposta ao estresse. Proteínas que venham a apresentar resposta significativa (indução, inibição) aos metais, poderão ser purificadas e parcialmente caracterizadas bioquimicamente e até molecularmente se forem distintas de outras já descritas na literatura. Eventuais mutantes tolerantes aos metais poderão ser estudados para utilização em fitorremediação. Ainda, mediante a uma resposta enzimática ao estresse induzido pelo metal, plantas transgênicas poderão ser produzidas super-expressando o gene que codifica a eventual enzima verificando-se os níveis de tolerância destas plantas em relação ao metal.

É evidente a importância de estudar culturas celulares, mas os parâmetros avaliados devem ser estendidos a plantas jovens. Dessa forma, com o conjunto destas informações será possível traçar estratégias de melhoramento diretamente relacionados com programas de fitorremediação de solos contaminados e monitoramento ambiental, uma vez que o estudo das respostas em diferentes organismos pode eleger genótipos tanto bioindicadores como fitorremediadores. 


\section{REFERÊNCIAS BIBLIOGRÁFICAS}

AGENCY FOR TOXIC SUBSTANCES AND DISEASE REGISTRY. Toxicological profile for nickel. Nova York: ASTDR. 1997. 262 p.

AGENCY FOR TOXIC SUBSTANCES AND DISEASE REGISTRY. Toxicological profile for aluminum. Nova York: ATSDR, 1999: 352 p.

AGENCY FOR TOXIC SUBSTANCES AND DISEASE REGISTRY. Toxicological profile for cadmium. Nova York: ATSDR, 1999b. 397 p.

ALLEN, R.D. Dissection of oxidative stress tolerance using trangenic plants. Plant Physiology, v.107, n.4, p.1049-1054, 1995.

ALSCHER, R.G. Biosynthesis and antioxidant function of glutathione in plants. Physiologia Plantarum, v.77, n. 3, p.457-464, 1989.

ALSCHER, R.G.; DONAHUE, J.L.; CRAMER, C.L. Reactive oxygen species and antioxidants relationship in green cells. Physiologia Plantarum, v.100, p.224-233, 1998. 
ALSCHER, R.G.; ERTURK, N.; HEATH, L.S. Role of superoxide dismutase (SODs) in controlling oxidative stress in plants. Journal of Experimental Botany, v. 53, n.372, p.1331-1341, 2002.

AMADO FILHO, G.M.; ANDRADE, L.R.; KAREZ, C.S.; FARINA, M.; PFEIFFER, W.C. Brown algae species as biomonitors of $\mathrm{Zn}$ and $\mathrm{Cd}$ at Sepetiba Bay, Rio de Janeiro, Brazil. Marine Environmental Research, v.48, p.213-224, 1999.

ANDERSON, M.D.; PRASAD, T.K.; STEWART, C.R. Changes in isozymes profiles of catalase, peroxidase and glutatione reductase during aclimation to chilling in mesocotyls of maize seedlings. Plant Physiology, v.109, n.4, p.1247-1257, 1995.

ANDREA,H.; FISCHIT, I.; BACH, T.J. Differencial interation of branch-specific inhibitors of isoprtenoid biosynthesis with cell-cycle progression in tobacco BY-2 cells. Physiologia Plantarum, v.110, p.342-349, 2000.

ANGELINI, R.; FEDERICO, R. Histochemical evidence of polyamine oxidation and generation of hydrogen peoxide in the the cell wall. Journal of Plant Physiology, v.135, p.212-217, 1989.

ANGELOVA, M.B.; PASHOVA, S.B.; SLOKOSKA, L.S. Comparison of antioxidant enzyme biosynthesis by free and immobilized Aspergillus nidulans cells. Enzyme and Microbial Technology, v.26, p.544-549, 2000.

ARDUINI, I.; GODBOLD, D.L.; ONNIS, A. Cadmium and copper uptake and distribution In Mediterranean Tree Seedlings. Physiologia Plantarum, v.97, n.1, p.111-117, 1996. 
ARISI, A.C.M.; MOCQUOT, B; LAGRIFFOUL, A. Responses to cadmium in leaves of transformed poplars overexpressing gamma-glutamylcysteine synthetase. Physiologia Plantarum , v.109, n.2, p.143-149, 2000.

AZEVEDO, R.A.; ALAS, R.M.; SMITH, R.J.; LEA, P.J. Response of antioxidant enzymes to transfer from elevated carbon dioxide to air and ozone fumigationn, in the leaves and roots of wild-tipe and a catalase-deficient mutant of barley. Physiologia Plantarum, v.104, n.2, p.280-292, 1998.

BAMBANG, Y.; CHARMANTIER, G.; THUET, P.; TRILLES, J.P. Effect of Cadmium On Survival and Osmoregulation of Various Developmental Stages of the Shrimp Penaeus-Japonicus (Crustacea, Decapoda). Marine Biology, v.123, p.443450, 1995.

BARCELÓ, J.; VAZQUEZ, M.D.; POSCHENRIEDER, C. Structural and ultrastructural disorders in cadmium treated bush bean (Phaseolus vulgharis L.). New Phytologist, v.108, n.1, p.37-49, 1988.

BHATTACHARJEE, S. Membrane lipid peroxidation, free rtadical scavengers and ethylene evolution in Amaranthus as affected by lead and cadmium. Biologia Plantarum, v.40, n.1, p.131-135, 1998.

BECK, A.; LENDZIAN, K.; OVEN, M.; CHRISTMANN, A.; GRILL, E. Phytochelatin synthase catalyzes key step in turnover of glutathione conjugates. Phytochemistry, v62, p. 423-431, 2003.

BERGER, S., WEICHERT, H., PORZEL, A.; WASTERNACK, C.; KÜHN, H.; FEUSSNER, I. Enzymatic and non-enzymatic lipid peroxidation in leaf development. Biochimica et Biophysic Acta, v.1533, p.266-276, 2001. 
BERNARD, A.; LAUWERYS, R. Cadmium in human population. Experientia, v.40, n.2, p. 143-152, 1984.

BEUCHAMP, C.; FRIDOVIC, I. Superoxide dismutase - Improved assays and assay applicable to acrylamide gels. Analytical Biochemistry, v.44, p.276, 1971.

BIELESKY, R.L.; TURNER, N.A. Separation and estimationa of amino acids in crude pant extract by thin-lay electrophoreses and chromotography. Analytical Biochemitry, v.17, n.2, p.278-293, 1986b.

BOLWELL, G.P.; BUTT, V.S., DAVIES, D.R.; ZIMMERLIN, A. The origin of the oxidative burst in plants. Free Radical Research, v. 23, p.517-532, 2003.

BOWLER, C.; VANCAMP, W.; VANMONTAGU, M.; INZE, D. Superoxidedismutase in plants. Critical Reviews in Plant Sciences, v.13, n.3, p.199-218, 1994.

BOWLER, C.; VAN MONTAGU M.; INZE, D. Superoxide dismutase and stress tolerance. Annual Review of Plant Physiology and Plant Molecular Biology, v.43, p.83-116. 1992.

BRADFORD, M. .M. A rapid and sensitive method for the quantitation of microgram quantities of protein utilizing the principle of protein-dye binding. Analytical Biochemistry, v.72, p.248-259, 1976.

BRIAT, J.F.; LEBRUN, M. Plant responses to metal toxicity. Comptes Rendus De L Academie Des Sciences Serie Iii -Sciences De La Vie-Life Sciences, v.322, p.43-54, 1999. 
BROWN, D.P; BECKETT, R. P. Intracellular and extracellular uptake of cadmium by the moss Rhytidiadelphus -Squarrosus. Annals of Botany, v.55, p.179-188, 1985.

BUEGE, J.A.; AUST, S.D. Microsomal lipid peroxidation. Methods Enzymol., v.52, p.302-310, 1978.

CALERA, J.A.; SANCHEZ-WEATHERBY, J.; LOPES-MEDRANO, R.; LEAL, F. Distinctive properties of the catalase B of Aspergillus nidulans. FEBS Letters, v.475, p.117-120, 2000.

CAMPA, A. Biological roles of plant peroxidases: known and potential function, In: Peroxidases in Chemistry and Biology. Everse, J.; Everse, K.E.; Grisham, M.B. (Eds.)., Florida: CRC Press, Boca Raton, 1991. vol. II, p. 25-50.

CARVALHO, C.E.V.; LACERDA, L.D.; GOMES, M.P. Heavy-metal contamination of the marine biota along the Rio-de Janeiro coast, Se-Brazil. Water Air and Soil Pollution, v.57, p.8:645-653, 1991.

CHAOUI, A.; MAZHOUDI, S.; GHORGBAL, M.H.; EL FERJANI, E. Cadmium and zinc indution of lipid peroxidation and effects on antioxidants enzyme activities in bean (Phaseolus vulgaris L.). Plant Science, v.127, n.2, p.139-147,1997.

CHAVES, I. REAGALADO. A.P.; CHEN, M.; RICARDO, C.P.; SHOWALTER, A.M. Programmed cell death induced by $(\beta \text {-D-galactosyl })_{3}$ Yariv reagent in Nicotiana tabacum BY-2 suspension-cultured cells. Physiologia Plantarum, v.116, p.548$553,2002$. 
CHEN, H.Y.; LIU, W.Y. The molecular evolution of superoxide dismutase based on its distribution and structure. Progress in Biochemistry and Biophysics, v.23, n.5, p.408-413, 1996.

CHEN, J.J.; ZHOU, J.M.; GOLDSBROUGH, P.B. Characterization of phytochelatin synthase from tomato. Physiologia Plantarum, v.101, n.1, p.165-172, 1997.

CHEN, S.L.; KAO, C.H. Glutathione reduces the inhibition of rice seedlings root growth caused by cadmium. Plant Growth Regulation, v.16:249, p.252, 1995.

CLEMENS, S.; KIM, E.J.; NEUMANN, D.; SCHROEDER, J.I. Tolerance to toxic metals by a gene family of phytochelatins synthases from plants and yeast. EMBO Journal, v.18, n.12, p.3325-3333, 1999.

COBBETT, C.S. A family of phytochelatins synthase genes from plants, fungal and annimal species. Trends in Plant Sciences, v.4, p.335-337, 1999.

COBBETT, C.S. Phytochelatins and their roles In Heavy Metal detoxification. Plant physiology, v.123, p. 825-832, 2000.

COBBETT, C.S.; GOLDSBROUGH, P. Phytochelatins and metallothioneins: roles in heavy metal detoxification and homeostasis, Annual Review Plant Biology, v.53, p. 159-182, 2002.

COMPANHIA DE TECNOLOGIA DE SANEAMENTO AMBIENTAL. Relatónio de Qualidade das Águas Interiores do Estado de São Paulo 2000. São Paulo. São Paulo: 2001b. 73 p. (CETESB. Série Relatórios). 
COMPANHIA DE TECNOLOGIA DE SANEAMENTO AMBIENTAL. Relatório de estabelecimento de valores orientadores para solos e águas subte rrâneas no estado de São Paulo. São Paulo: 2001b. 246 p. (CETESB. Série Relatórios Ambientais).

COOLEY RN, THURMAN DA, TOMSETT AB Molecular mechanisms of heavymetal tolerance in aspergillus-nidulans. Heredity 57: 133-134 Part 11986.

CORPAS, F.J.; SANDALIO, L.M.; PALMA, J.M.; LEIDI, E.O.; HERNANDEZ, J.A.; SEVILLA, F.; DEL RIO, L.A. Subcellular-distribution of superoxide-dismutase in leaves of ureide-producing leguminous plants. Physiologia Plantarum, v.82, n. 2, p.285-291, 1991.

COWAN, C. K., FOX, T. C., GARVIN, D.F.; KOCHIAN, L.V. The role of irondeficiency stress responses in stimulating heavy-metal transport in plants. Plant Physiology, v.116, p.1063-1072, 1998.

CREISSEN, G.P.; MULLINEAUX, P.M. Cloning and characterization of glutathionereductase cDNAs and identification of 2 genes encoding the tobacco enzyme. Planta, v.197, n.2, p.422-425, 1995 b.

CREISSEN, G.P.; BROADBENT, P.; KULAR, B.; REYNOLDS, H.; WELLBURN, A.R.; MULLINEAUX, P.M. Manipulation of glutathione-reductase in transgenic plants-implications for plants responses to environmentalstress. Proceedings of the Royal Society of Edinburgh, Section B - Biological Sciences, v.102, p.167175, 1994a. 
CREISSEN, G.P.; EDWARDS, E.A.; MULLINEAUX, P.M. Glutatione reductase and ascorbate peroxidase. In: FOYER, C.H.; MULLINEAUX, P.M. (Ed.) Causes of Photooxidative Stress and Amelioration of Defense Systems in Plants. Flórida: CRC Press Boca Raton, 1994. p 343-364.

CUNNINGHAM, S.D.; BERTI, W.R.; HUANG, J.W. Phytoremediation of contaminated soils. Tibtech, v13, p.393-397, 1995.

CUYPERS, A.; VANGRONSVELD, J.; CLIJSTERS, H. The chemical behaviour of heavy metals plays a prominent role in the induction of oxidative stress. Free Radical Research, v.31, p.S39-S43, 1999.

DALURZO, H.C.; SANDALIO, L.M.; GOMEZ, M.; DEL RIO, L.A. Cadmium infiltration of detached pea leaves. Effect on its activated oxygen metabolism. Phyton-Annales Rei Botanicae, v.37, n.3, p.59-64, 1997.

DANIEL, V. Glutathione S-transferase: gene structure and regulation of expresiion. Crit. Ver. Biochemistry. Molecular Biology., v.28, p.173-207, 1993.

DA SILVA, J.J.R.F.; WILLIAMS, R.J.P. The Biological Chemistry of the Elements: The Inorganic Chemistry of Life. Clarendon Press. Oxford: Clarendon Press, 1991. $561 \mathrm{p}$.

DAS, P.; SAMANTARAY, S.; ROUT, G.R. Studies on cadmium toxicity in plants: a review. Environmental Pollution, v.98, p.29-36, 1997. 
DE, S.K.; PARIA, B.C.; DEY, S.K.; ANDREWS, G.K. Stage-specific effects of cadmium on preimplantation embryo development and implantation in the mouse. Toxicology, v. 80, p.13-25, 1993.

DE PINTO, M.; TOMMASI, F.; DE GARA, L. Enzymes of the ascorbate biosynthesis and ascorbate-glutathione cycle in cultured cells of tobacco Bright Yellow 2. Plant Physiology Biochemistry., v.38, p.541-550, 2002.

DEY, S.K.; KAR, M. Antioxidant efficiency during callus initiation from mature rice. embryo. Plant and Cell Physiology, v.36, n.4, p.543-549, 1995.

DI TOPPI, L.S.; GABBRIELLI, R. Response to cadmium in higher plants. Environmental and Experimental Botany, v.41, n.2, p.105-130, 1999.

DIXIT, V.; PANDEV, V.; SHVAM, R. Differential antioxidative responses to cadmium in roots and leaves of pea (Pisum sativum L. cv. Azad). Journal of Experimental Botany, v.52,n.358,p.1101-1109, 2001.

DIXON, D.P.; LAPTHORN, A.; EDWARDS, R. Plant glutathione transferases. Genome Biology, v.3, p.1-10, 2002.

DÖNMEZ, G.; AKSU, Z. The effect of copper (II) ions on the growth and bioaccumulation properties of some yeasts. Process Biochemistry, v.3, n.135-142, 1999. 
EDWARDS, E.A.; RAWSTHORNE, S.; MULLINEAUX, P.M. Subcellular distribution of multiple forms of glutathione reductase in leaves of pea (Pisum sativum L.). Planta, v.180, n.2, p.278-284, 1990.

EL-SHINTINAWY, F. Glutathione counteracts the inhibitory effect induced by cadmiun on Photosynthetic process in soybean. Photosynthetica, v.36, n.1/2, p.171-179, 1999.

ERDEI, L.; SZEGLETEZ, Z; BARABAS, N.J.; PESTENAY, A.; FULOP, K.; KALMA, K., TOTH, B.; DER, A. Environmental stress and the biological chock in plants: changes of rhytmic behavior of carboyfrates, antioxidant enzymes resistence by salimity. Journal of Plant Physiology, v.152, n.3, 265-267, 1998.

FADZILLAH, N.M.; GILL, V.; FINCH, R.P.; BURDON, R.H. Chilling, oxidative stress and antioxidant responses in shoot cultures of rice. Planta, v.199, p.552-556, 1996.

FIELDES, M.A.; GERHARDT, K.E. Flax guaiacol peroxidases can be used to illustrate the possibility of misinterpreting the effects of stress on the activity of developmentally regulated enzymes. Plant Science, v.132, p.89-99,1998.

FLURKEY, W.H., JEN, J.J. Peroxidase and polyphenol oxidase activities in developing peaches Journal of Food Science, v.43, n.6, p.1826-\&, 1978

FODOR, A.; SZABÓ-NAGY, A., ERDEI, L. The effects of cadmium on the fluidity and $\mathrm{H}^{+}$-ATPase activity of plasma membranefrom sunflower and wheat roots. Journal of Plant Physiology, v.14, p.787-792, 1995. 
FOJTOVÁ, M.; FULNECKOVA, J.; FAJKUS, J., KOVARIK, A. Recovery of tobacco cells from cadmium stress is accompanied by DNA repair and increased telomerase activity. Journal of Experimental Botany, v.53, n.378, p.2151-2158, 2002.

FORNAZIER, R.F.; FERREIRA,R.R.; VITÓRIA, A.P.; MOLINA, S.M.G.; LEA, P.J.; AZEVEDO, R.A. Effects of cadmium on antoxidant enzyme activities in sugar cane. Biologia Plantarum, v.45, n.1, p.91-97, 2002a.

FORNAZIER, R.F.; FERREIRA,R.R.; PEREIRA G.J.G.; MOLINA, S.M.G.; SMITH, R.J. LEA, P.J.; AZEVEDO, R.A. Cadmium stress in sugar cane callus cultures: Effect on antioxidant enzymeson Plant Cell, Tissue and Organ Culture, v.75, p.125-131, $2002 b$.

FOYER, C.H.; LELANDAIS, M.; KUNERT, K.J. Photoxidative stress in plants. Physiologia Plantarum, v.92, n.4, p.696-717, 1994.

FRANCIS, D.; DAVIES, M.S.; BRAYBROOK, C.; JAMES, N.C.; HERBERT, R.J. An effect of zinc on Mphase and G1 of the plant celll cycle in the synchronous TBY2 tobacco cell suspension. Journal of Experimental Botany, v.46, p.1887-1894, 1995.

FRUGOLI, J.A.; ZONGH, H.H.; NUCCIO, M.L.; MCCOURT, P.; MCPEEK, M.A.; THOMAS, T.L.; MCCLUNG, C.R. Catalase is encoded by a multigene family in Arabidopsis thaliana (L.) Heynh. Plant Physiology, v.112, n.1, p.327-336, 1996.

GABBRIELLI, R.; PANDOLFINI, T.; VERGNANO, O.; PALANDRI, M.R. Comparison of two serpentine species with different nickel tolerance strategies. Plant and Soil, v.122, n.2, p.271-277, 1990. 
GALLEGO, S.M.; BENAVIDES, M.P. ; TOMARO, M.L. Effect of cadmium ions on antioxidant defense system in sunflower cotyledons. Biologia Plantarum, v.42, n.1, p.49-55, 1999.

GALLEGO, SM.; BENAVIDES, M.P. ; TOMARO, M.L. Effect of cadmium ions on antioxidant defense system in sunflower cotyledons. Biologia Plantarum, v.42, n.1, p.49-55, 1999.

GALLEGO, S.M.; BENAVÍDES, M.P.; TOMARO, M.L. Effect of heavy metal ion excess on sunflower leaves: evidence for involvment of oxidative stress. Plant Science, v.121, n.2, p.151-159, 1996a.

GALLEGO, S.M.; BENAVIDES, M.P.; TOMARO, M.L. Oxidative damage caused by cadmium choride in sunflower (Helianthus annuus L.) plants. PhytonInternational Journal of Experimental Botany, v.58, n.1-2, p.41-52, $1996 \mathrm{~b}$.

GALLI, U.; SCHUEPP, H.; BRUNOLD, C. Thiols in cadmium and copper-treated maize (Zea mays L.). Planta, v.198, n.1, p.139-143, 1996.

GASPAR, T.H.; PENEL, C.L.; THORPE, T.; GREPPIN, H. Peroxidases: a survey of their biochemical and physiological roles in higher plants. Genève: Universitè de Genevè, Centre de Botanique, 1982. 313p.

GEELEN, D.N.; INZÉ, D.G. A bright future for the bright yellow-2 cell culture. Plant Physiology, v.127, p.1375-1379, 2001.

GHOSHROY, S.; FREEDMAN, K.; LARTEY, R.; CITOVSKY, V. Inhibition of plant viral systemic infection by non-toxic concentrations of cadmium. The Plant Journal, v.13, p.591-602, 1998. 
GIANNOPOLITIS, C.N.; RIES, S.K. Superoxide dismutases .1. occurrence in higherplants. Plant Physiology, v.59, p.309-314, 1977.

GIMENO-GARCIA, E.; ANDREU, V.; BOLUDA, R. Heavy metals incidence in the application of inorganic fertilizers and pesticides to rice farming soils. Environmental Pollution, v.92, p.19-25, 1996.

GODBOLD, D.I.; HUTTERMANN, A. effect of zinc, cadmium and mercury on root elongation of picea-abies (karst) seedlings, and the significance of these metals to forest. Environmental Pollution Series A-Ecological And Biological, v.38, n.4, p.375-381, 1985.

GOLDEBERG, R.; IMBEERTY, A.; LIBERMAN, M.; PRAT, R. Relationship between peroxidatic activities and cell wall plasticity. In: GREEPIN, H.; PENEL, C.; GASPER JR., T. (Eds.). Molecular and Physiological Aspects of Plant Peroxidases. University of Geneva, Switzerland, 1986. p.208-220.

GOLDSBROUGH, P.B. Metal Tolerance in Plants: the role of phytochelatins and metallothioneins. In: TERRY, N.; BANUELOS, G.S. (Eds). Phytoremediation of contaminated soils soil and water. Florida: CRC Press, Boca Raton, 1998. p. 221-233.

GRILL, E.; THUMANN, J.; WINNACKER, E.L.; ZENK, M.H. Phytochelatins, the heavy metals binding peptides of plants are synthetised from glutathione by a especific gammaglutamylcysteine dipeptide transpeptidase (phytochelatin syntase) Proceedings of the National Academy of Sciences of the U.S.A., v.86, n.18, p.6838-6842, 1989.

GRILL, E.; WINNACKER, E.L.; ZENK, M.H. Phytochelatins - the principal heavy- metal complexing peptides of higher plants. Science, v.230, n.4726, p.674-676, 1985. 
GRISEBACH, H. LIGNINS, In: Conn, E.E. (ed.) The Biochemistry of Plants. New York: Academic Prev, 1981. vol. 7, p.457-478,

GUELFI, A. Resposta das enzimas antioxidativas em linhagens do fungo Aspergillus sp. Na presença do metal pesado cádmio. Piracicaba, 2001 60p. Dissertação Escola Superior de Agricultura 'Luiz de Queiroz”, Universidade de São Paulo.

GUO, Y.; MARSCHNER, H. Uptake, distribution, and binding of cadmium and nickel in different plant species. Journal of Plant Nutrition, v.18, p.2691-2706, 1995.

GWOZDZ, E.A.; PRZYMUSINSKI, R.; RUCINSKA, R.; DECKERT, J. Plant Cell responses to heavy metals: molecular and physiological aspects. Acta Physiologiae Plantarum, v.19, n.4, p.459-465, 1997.

HA, S.B.; SMITH, A.P.; HOWDEN, R.; DIETRICCH, W.M.; BUGG, S.; O'CONNEL, M.J.; GOLDSBROUGH, P.B.; COBBETT, C.S. Phytochelatin synthase genes from Arabdopsis and Schizosaccharomyces pombe. Plant Cell, v.11, n.6, p.1153-1163, 1999.

HALLIWELL, B. Oxidative stress in cell culture: na under-appreciated problem? FEBS Letters, v.540, p.3-6, 2003.

HAVIR, E.A.; MCHALE, N.A. Regulation of catalase activity in leaves of Nicotiana sylvestris by high $\mathrm{CO}_{2}$. Plant Physiology, v.89, p.952-957, 1989.

HAYAKAWA, T.; KANEMATSU, S.; ASADA, K. Occurence of Cu,Zn-Superoxide idsmutase in the intrathylakoid space of spinach-chloroplasts. Plant and Cell Physiology, v.25, p.883-889, 1984. 
HEATH, R.L.; PACKER, L. Photoperoxidation in isolated chloroplasts. I. Kinetics and stoichiometry of fatty acid peroxidation. Arch Biochemistry Biophysic., v.125, p.189-198, 1968.

HOLTMAN, W.L.; HEISTEK, J.C.; MATTER, K.A.; BAKHUIZEN, R.; DOUMA, A.C. $\beta$-Oxidation of fatty acids is linked to the glyoxylate cycle in the aleurone but not in the embryo of germinating barley. Plant Science, v.94, n.1, p.43-53, 1994.

HOUOT, V.; ETIENNE, P.; PETITOT, A.S.; BARBIER, S.; BLEIN, J.P.; SUTY, L. Hydrogen peroxide induces cell death features in cultured tobacco BY-2 cells, in a dode-dependent manner. Jornal of Experimental. Botany, v.52, p1721-1730, 2001.

HOWDEN, R.; ANDERSEN, C.R.; GOLDSBROUGH, P.B.; COBBETT, C.S. A cadmium-sensitive, glutathione-deficient mutant of Arabidopsis-thaliana. Plant Physiology,v.107, n.4, p.1067-1073, 1995.

IANNELli, M.A., PIETRINI, F., FIORE, L.; PETRILlI, L, MASSACCI, A. Antioxidante responses to cadmium in Phragmites australis plants. Plant Physiology and Biochemistry, v.40,p.977-982, 2002.

IKEDA, M., ZHANG, Z.W., MOON, C.S.; SHIMBO, S.; WATANABLE N.H.; MATSUDA, N.I. Possible effects of environmental cadmium exposure on cadmium function in the japanese general. Population. Int. Arch. Occup. Environ Health, v.73, n.1, p.15-25, 2000.

ISTOMIN, A.V.; IUDINA, T.V.; NIKOLAEVA, N.I.; KHAMIDULIN, R.S.; AGMINA, R.S. Ilygienic aspects of safe use of agrochemicals. Vopr Pitan v.68, n.4, p.41-44, 1999. 
IWAMOTO, M.; MAEKAWA, M.; SAITO, A. Evolutionary relationship of plant catalase genes inferred from exon-intron structures: isozyme divergence after the separation of monocots and dicots. Theoretical and Applied Genetics, v.97:9-19, 1998.

JACKSON P.J., DELHAIZE E, KUSKE C.R. Biosynthesis and metabolic roles of cadystins (Gamma-Ec)nG and their precursors in Datura-Innoxia Plant And Soil v.146, n.1/2, p.281-289, 1992

JARUB L.; ELINDER C.G.; SPNG G. Cumulative blood-cadmium and tubular proteinuria. Int. Arch. Occup. and Environ. Health, v.60, p.223, 1988.

JEMAL, F.; ZARROUK, M., GHORBAL, M.H. Effect oc cadmium on lipid composition of pepper. Biochemical Society Transactions, v.28, p.907-910, 2000.

JORDÃO, C.P.; DA SILVA, A.C.; PEREIRA, J.L.; BRUNE, W. Contaminação por crômio de rios provenientes de curtumes em Minas Gerais. Química Nova, v.22, p.47-52,1999.

KANG, Y.J.; ENGER, M.D. Cadmium cytotoxicity correlates with the changes in glutathione content that occur during the logarithmic growth-phase of A549- T27 cells. Toxicology Letters, v.51, p.23-28, 1990

KANJI VK, MIHAS TA, MALIAKKAL RJ, DESIAH D, MIHAS AA Alphatocopherol reverses the lipid-peroxidation induced by $\operatorname{ccl}(4)$ and d-galactosamine in the rat Faseb Journal, v.9, n. 3, 1995. 
KATO, N.; ESAKA., M. Changes in ascorbate oxidase gene expresiion and ascorbate levels in tobacco cells, Physiologia Plantarum., v.105, p.321-329, 1999.

KAYALI, H.A.; TARHAN, L. Influence of zinc and copper ions on metal transport, antioxidant system responses and membrane LPO levels of $F$. equiset and $F$. acumination. Enzyme and Microbial Technology, v.33, p.828-835, 2003.

KEFALA, M.I.; ZOUBOULIS, A.I.; MATIS, K.A. Biosorption of cadmium ions by Actinomycetes and separation by flotation. Environmental Pollution, v.104, p.283293, 1999.

KELLER, T., DAMUDE, H.G.; WERNER, D.; DOERNER, P., DIXON, R.A.; LAMB, C. A plant homolog of the neutrophyl NADPH oxidase subnit gene encodes a plasma membrane protein with $\mathrm{Ca}^{2+}$ binding motifs. The Plant Cell, v.10, p.255-266, 1998.

KERK NM, FELDMAN LJ A biochemical-model for the initiation and maintenance of the quiescent center - implications for organization of root-meristems Development 121 (9): 2825-2833 SEP 1995.

KESSELER, A.; BRAND, M.D. The mechanism of the stimulation of state 4 respiration by cadmium in potato tuber (Solanum tuberosum) mitochondria. Plant Physiology and Biochesmistry, v.33, p.519-528, 1995.

KLIEBENSTEIN, D.J.; MONDE, R.A.; LAST, R. L. Superoxide dismutase in Arobidopsis: An eclectic enzyme family with disparate regulation and protein localization. Plant Physiology ., v.118, p.637-650, 1998. 
KRAUS, T.E.; EVANS, R.C.; FLETCHER, R.A.; PAUL, S.K.P. Paclobutrazol enhances tolerances to increased levels of UV-B radiation in soybean (Glycine max) seedlings. Canadian Journal Botany, v.73, n.6, p.797-806, 1995.

KRUPA, Z. Cadmium-induced changes in the composition and structure of the lightharvesting chorophyll $\mathrm{a} / \mathrm{b}$ protein complex II in radish cotyledons. Physiologia Plantarum, v.73, n.4, p.518-524, 1998.

KUMAR, R.; PANT, N.; SRIVASTAVA, S.P. Chlorinated pesticides and heavy metals in humam semen. International Journal of Andrology, v.23, n.3, p.145-149, 2000.

LAGRIFFOUL, A.; MOCQUOT, B.; VANGRONSVELD, J.; MENCH, M. Cadmium toxicity effects on growth, mineral and chlorophyll contents, and activities of stress related enzymes in young maize plants (Zea mays L.). Plant and Soil, v.200, p.241$250,1998$.

LARSEN, J. The influence of growth-phase and culture conditions of Tetrahymena on effects of cadmium. Toxicology, v.58, p.211-223, 1989.

LAUWERYS, R.R. Industrial chemical exposure: guidelines for bilogical monitoring. Davis: Biom Public; 1983. P.17-22.

LEA, P.J.; WELLBURN, F.A.M.; WELLBURN, A.R.; CREISSEN， G.P.; MULLINEAUX, P.M. Use of transgenic plants in the assessment of responses to atmospheric pollutants. In: DE KOK, L.J.; STULEN, I. (Eds.). Responses of plant metabolism to air pollution and global change. Leiden, The Netherlands: Backhuys Publishers, 1998. p.241-250. 
LEE, D.H.; LEE, C.B. Chilling stress-induced changes of antioxidant enzymes in the leaves os cucumber; in gel enzyme activity assays. Plant Sciences, v.159, n.1, p.75-85, 2000.

LEE, H.; JO, J.; SON, D. Molecular cloning na characterization of the gene encoding glutathione rreductase in Brassica campestris. Biochimica et Biophysica Acta Gene Structure and Expression, v.1395, n.3, p.309-314, 1998.

LEE, M.Y.; SHIN, H.W. Cadmium-induced changes in antioxidante enzymes from the marine alga Nannochloropsis occulata. Journal of Applied Phycology, v.15, n.1, p.13-19, 2003.

LEOPOLD, I.; GÜNTHER, D.; SCHMIDT, J.; NEUMANN, D. Phytochelatins and heavy metal tolerance. Phytochemistry, v.50, p.1323-1328, 1999.

LESHEM YY, KUIPER PJC, ERDEI L, LURIE S, PERL-TREVES R Do selye's mammalian "GAS" concept and "co-stress" response exist in plants? Annals Of The New York Academy Of Sciences, v.851, p.199-208, 1998.

LESSER, M.P.; STOCHAJ, W.R. Protoadaptation and protection against active forms of oxygen in the symbiotic prokaryote Prochloron sp. and its ascidian host. Applied Environmental Microbiology, v.56, p.1530-1535, 1990.

LEWIS, G.P.; COUGHLIN, L.; JUSKO, W.; HARTZ, S. Contribuition of cigarette smoking to cadmium accumulation in mam. Lancet, v.1, p.291-292, 1972.

LICHTENTHALER, H.K. Vegetation stress: An introduction to the stress concept in plants. Journal Of Plant Physiology, v.148, p.4-14, 1996. 
LOZANO-RODRIGUEZ, E.; HERNANDEZ, L.E.; BONAY, P.; CARPENA-RUIZ, R.O. Distribution of cadmium in shoot and root tissues of maize and pea plants: physiological disturbances. Journal of Experimental Botany, v.48, p.123-128, 1997.

LUBBEN, S.; SAUERBECK, D. Transfer factors and transfer coefficients for heavy metal transfer from soil to plants. In: SAUERBECK, D.; LUBBEN, S. (Eds.) Auswirkinng von Siedlungsabfallen auf Boden, Bodenorganismen und Pflanzen. Berichte aus der Okologischen Forschung. Germany: Forschungszentrum Julich Gmb, Julich, . 1991. v.6.

MAITANI, T., KUBOTA, H. SATO K E YAMADA, T. The composition of metals bound to class III metallothionein (phytochelatin and its desglycyl peptide) induced by various metals in root cultures of Rubia tinctorum. Plant Physiol., v.110, p.1145-1150, 1996.

MAKSYMIEC, W. Effect of copper on cellular processes in higher plants. Photosynthetica, v.34, p.321-342, 1997.

MAKSYMIEC, W.; BASZYNSKI, T. Different susceptibility of runner bean plants to excess copper as a function of the growth stages of primary leaves. Journal of Plant Physiology, v.149, p.217-221, 1996.

MALANGA, G.; KOZAK, R.G.; PUNTARULO, S. N-acetylcysteine-dependent protection against UV-B damage in two photosynthetic organisms. Plant Science , v.141, p.129-137, 1999. 
MALAVOLTA, E. Fertilizantes e seu impacto ambiental: micronutrientes e metais pesados, mitos, mistificação e fatos. São Paulo: Produquímica. 1994. 153 p.

MALLICK, N.; MOHN, F.H. Reactive oxygen species: response of algal cells. Journal of Plant Physiology, v.157, p.183-193, 2000.

MALLICK, N.; RAI, L.C. Response of the antioxidant systems of the nitrogen fixing cyanobacterium Anabaena doliolum to copper. Journal of Plant Physiology, v.155, p.146-149, 1999.

MANNAZZU, I.; GUERRA, E.; FERRETTI, R.; PEDICONI, D.; FATICHENTI, F. Vanadate and copper induce overlapping oxidative stress responses in the vanadatetolerant yeast Hansenula polymorpha. Biochimica et Biophysica Acta, v.1475, p.151-156, 2000.

MARRS, K.A. The functions and regulation of glutathione S-transferase in plants. Annual Review of Plant Physiology and Molecular Biology, v.47, p.127-158, 1996.

MARRS, K.A.; WALBOT, V. Expression and RNA splicing of the maize glutathione S-transferase Bronze2 gene is regulated by cadmium and other stresses. Plant Phisyology, v.113, n.1, p.93-102, 1997.

MATSUNO, H.; URITANI, I. Physiological behavior of peroxidase isozymes in sweet potato root tissue injured by cutting or with black rot. Plant \& Cell Physiology, v.13,p.1091-1101, 1972. 
MATTIAZZO-PREZOTTO, M.E. Comportamento de cobre, Cd, crômio, níquel e zinco adicionados a solos de clima tropical em diferentes valores de $\mathrm{pH}$. Piracicaba, 1994. 197p. Tese (Livre-Docência) - Escola Superior de Agricultura "Luiz de Queiroz", Universidade de São Paulo.

MATTSON, M.P. Answering the old age question. Chemistry \& Industry. 1998. v.20, p.843-848.

MCCORDE, J.M.; FRIDOVICK Superoxide dismutases: na enzimatic function for erythrocuprein (hemocuprein). Journal of Biology Chemistry, v.244, p.6049-6055, 1969.

MEJÁRE, M.; BÜLOW, L. Metal-binding proteins and peptides in bioremediation and phytoremediation of heavy metals. TRENDS in Biotecnology, v.19, n2, p. 67-72, 2001.

MELO, L.C; DOS SANTOS, J.B., RAMALHO, M.A.P. Choice of parents to obtain common bean (Phaseolus vulgaris) cultivars tolerant to low temperatures at the adult stage. Brazilian Journal Of Genetics, v.20, n.2, p.283-292, 1997.

MEUWLY P, RAUSER WE Alteration of thiol pools in roots and shoots of maize seedlings exposed to cadmium - adaptation and developmental cost Plant Physiology, v.99, n.1, p.8-15, 1992.

MOHAN. B.S.; HOSETTI, B.B. Potential phytotoxicity of lead and cadmium to Lemna minor grown in sewage stabilization ponds. Environmental Pollution, v.98, n.2, p.233-238, 1997.

MURASHIGE, T.; SKOOG, F. A revised medium for rapid growth and assays with tobacco tissue cultures. Physiologia Plantarum, v.15, n.3, p.473, 1962. 
NAGATA, T.; NEMOTOT, Y.; HASEZAWA, S. Tobacco BY-2 cell line as the "HeLa" cell in the cell biology of higher plants. International Review of Cytology, v.132, p.1$30,1992$.

NAKAGAWA, N., SAKURAI, N. Increase in the amount of celAi protein in tobacco BY-2 cells by a cellulose biosynthesis inhibitor, 2-6 dichlorobenzonitrile. Plant Cell Physiol., v.39, p.779-785, 1998.

NETO, J.A.B.; SMITH, B.J.; MCALLISTER, J.J. Heavy metal concentrations in surface sediments in a nearshore environment, Jurujuba Sound, Southeast Brazil. Environmental Pollution, v.109, p.1-9, 2000.

NIYOGI, K.K. Photoprotection revisited: Genetic and Molecular Approaches. Annual Review of Plant Physiology and Plant Molecular Biology, v.50, p.333-359, 1999.

NOCTOR, G.; GOMEZ, L.; VANACKER, H.; FOYER, C.H. Interactions between biosynthesis, comportmentation and transport in the control of glutathione homeostasis and signalling. Journal of Experimental Botany, v.53, n.372, p.1283-1304, 2002.

NOCTOR, G.; FOYER, C.H. Ascorbate and glutathione: keeping active oxygen under control. Annual Review of Plant Physiology and Molecular Biology, v.49, p.249-279, 1998.

OLMOS, E.; MARTINEZ-SOLANO,J.R.; PIQUERAS, A.; HELLIN, E. Early steps in the oxidative burst induced by cadmium in cultured tobacco cells (BY-2 line). Journal of Expeirmental Botany, v. 54, n. 381, p.291-301, 2003. 
PAN, S.; YAU, Y. The isozymes of superoxide dismutase in rice. Botanical Bulletin of Academia Sinica, v.32, p.:253-258, 1991.

PANAGOPOULOS, I.; BORNMAN, J.F.; BJORN, L.O. The effect of UV-B and UV-C radiation on Hibiscus leaves determined by ultraweak luminescence and fluorescence induction. Physiology Plant, 76:461-465, 1989.

PANAGOPOULOS, I.; BORNMAN, J.F.; BJORN, L.O. Effects of ultraviolet radiation and visible light on growth, fluores-cence induction, ultraweak luminescence and peroxidase activity in sugar beet plants. Journal of Photochem. Photobiol, v.8, p.73-87, 1990.

PANDA, S.K.; CHAUDHURY, I.; KHAN, M.H. Heavy metals induce lipid peroxidation and affect antioxidants in wheat leaves. Biologia Plantarum, v.46, n.2, p.289-294, 2003.

PANDOLFIN, T; GABBRIELLI, R; CISCATO, N. Nickel toxicity in two durum wheat cultivars differing in drought sensitivy. Journal of Plant Nutrition, v.19, p.1611$1627,1996$.

PATRA, J.; PANDA, B.B. A comparison of biochemical responses to antioxidative and metal stress in seedlings of barley (Hordeum vulgare L.). Environmental Pollution, v.101, n.1, p.99-105, 1998. 
PAYETTE, Y.; LACHAPELLE, M.; DANIEL, C.; BERNIER, J.; FOURNIER, M.; KRZYSTYNIAK, K. Decreased interleukin-2 receptor and cell-cycle changes in murine lymphocytes exposed in-vitro to low-doses of cadmium chloride. International Journal of Immunopharmacology, v.17, p.235-246, 1995.

PERIN, G.; FABRIS, R.; MANENTE, S.; WAGENER, A.R.; HAMACHER, C.; SCOTTO, S. A five-year study on the heavy-metal pollution of Guanabara Bay sediments (Rio de Janeiro, Brazil) and evaluation of the metal bioavailability by means of geochemical. Water Research, v.31, p.3017-3028, 1997.

PEREIRA, G.J.G.; MOLINA, S.M.G.; LEA. P.J.; AZEVEDO, R.A. Activity of antioxidant enzymes in response to cadmium in Crotalaria juncea. Plant and Soil, v.239, p.123-132, 2002.

PETTERSON, O. Differences in cadmium uptake between plant species and cultivars. Swed Journal Agriculture Research, v.7, p.21-24, 1977.

POLIDOROS, A.N.; SCANDALIOS, J.G. Role of hidrogen peroxide and different classes of antioxidants in the regulation of catalase and glutathione S-transferase gene expression in maize (Zea mays L.). Physiologia Plantarum, v.106, p.112120, 1999.

PRASAD, M.N.V. Cadmium toxicity and tolerance in vascular plants. Environmental and Experimental Botany, 35:525-545, 1995.

RADY, A.A.; EL-SHEEKH, M.M.; MATKOVICS, B. Temperature shift-induced changes in the antioxidant enzyme system of cyanobacterium Synechosystis PCC6803. International Journal Biochemistry, 26:433-435, 1994. 
RAUSER, W.E. Phitochelatins and related pepitides. Structure. Biosynthesis and funcion. Plant Physiology, v.109, p.1141-1149, 1995.

REBAFKA, F.P., SHULZ, R.; MARSCHNER, H. Investigations of nickel availability in soils containing high geogenic nickel contents. Angew Botanik, v.64, p.317328, 1990.

REINHECKEL, T.; NOACK, H., LORENZ, S., WISWEDEL, I., AUGUSTIN, W. Comparison of protein oxidation and aldehyde formation during oxidative stress in isolated mitochondria. Free Radical Research, v.29, n.4, p. 297-305, 1998.

RICE-EVANS, C.A.; DIPLOCK, A.T.; SYMONS, M.C.R. Techniques in free radical research. In: BURDON, R.H.; VAN KNIPPENBERG, P.H. (Eds.). Laboratory techniques in biochemistry and molecular biology. London: Elsevier, 1991. v. 22, 291p.

RICHARDS, H.; DAS, S.; SMITH, C.J.; PEREIRA, L.; GEISBRECHT, A.; DEVITT, N.J., GAMES, D.E.; GEYSCHEM, J.V.; BRENTON, A.G.; NEWTON, R.P. Cyclic nucleotide content of tobacco BY-2 cells. Phytochemistry, v.61, p.531-537, 2002.

ROBINSON, N.J.; GUPTA, A.; FORDHAM-SKELTON, A.P.; CROY, R.D.R.; WHITTON, B.A.; HUCKLE, J.W. Prokaryotic metallothionein gene characterization and expression: chromosome crawling by ligation-mediated PCR. Proceedings of Royal Society, v. 242, p.241-247, 1990.

ROELS, H.A., HOET, P., LISON, D. Usefuness of biomarkers of exposure to inorganic, mercury, lead, or cadmium in controlling occupational and environmental risks of nephrotoxicity. Ren Fail, v.21, p.251-262, 1999. 
ROMERO-PUERTAS, M.C.; MCCARTHY, I.; SANDALIO, L.M.; PALMA, J.M.; CORPAS, F.J.; GÓMEZ, M.; DEL RIO, L.A. Cadmium toxicity and oxidative metabolism of pea leaf peroxisomes. Free Rad. Res., v.31, p.25-31, 1999.

SAHU, R.K.; KATSIFIS, S.P.; KINNEY, P.L.; CHRISTIE, N.T. Ni(Ii) Induced Changes in Cell-Cycle Duration and Sister- Chromatid Exchanges in Cultured Human-Lymphocytes. Mutation Research-Fundamental and Molecular Mechanisms of Mutagenesis, v.327, p.217-225, 1995.

SALT, D.E.; BLAYLOCK, M.; KUMAR, N.P.B.A.; DUSENKOV, V.; ENSLEY, B.D.; CHET, I.; RASKIN, I. Phytorremediation: A novel strategy for the removal of toxic metals from the environment using plants. Bio Technology, v.13, p.468-474, 1995.

SAMANTARAY, S.; ROUT, G.R.; DAS, P. Chromium and nickel tolerance of Trema orientalis (Blume) L. in tissue culture. Acta Physiologiae Plantarum, v.21, p.27-35, 1999.

SANDALIO, L.M.; DALURZO, H.C.; GÓMEZ,M.C., ROMERO-PUERTAS, M.C.; DEL RIO, L.A. Cadmium-induced changes in the growth and oxidative metabolism of pea plants. Journal of Experimental Botany, v.52, n.364, 2115-2126, 2001.

SAPLAKOGLU, U.; ISCAN, M. Sister chromatid exchanges in human lymphocytes treated in vitro with cadmium in $\mathrm{G}(0)$ and $\mathrm{S}$ phase of their cell cycles. Mutation Research-Genetic Toxicology and Environmental Mutagenesis, v.412, p.109-114, 1998. 
SCANDALIOS, J.G. Regulation and properties of plant catalases. In: FOYER, C. H. AND MULIUNEAUX, P.M. (Ed.) Causes of Photoxidative Stress and Amelioration of Defense Systems in Plants. Flórida: CRC Press, 1994. p. 275315.

SCANDALIOS, J.G. Oxygen stress and superoxide dismutases. Plant Physiology, v.101, p.7-12, 1993.

SCANDALIOS, J.G. Response of plant antioxidant defense genes to environmental stress. Advancess in Genetics, v.28, p.1-41, 1990.

SCHICKLER, H.; CASPI, H. Response of antioxidative enzymes to nickel and cadmium stress in hyperaccumulator plants of the genus Alyssum. Physiologia Plantarum, v.105, n.1, p.39-44, 1999.

SCHNEIDER S, BERGMANN L Regulation of glutathione synthesis in suspensioncultures of parsley and tobacco Botanica Acta, v. 108, p.34-40, 1995.

SCHÜTZENDUBEL, A.; POLLE, A. Plant responses to abiotic stresses: heavy metalinduced oxidative stress and protection by micorrhization. Journal of Experimental Botany, v. 53, n. 372, p.1351-1365, 2002.

SCHUTZENDUBEL， A.; SCHWANZ， P.; TEICHMANN， T.; GROSS， K.; LANGENFELD-HEYSER，R.; GODBOLD，D.L.; POLLE，A. Cadmium-induced changes in antioxidative systems, hydrogen peroxide content and differentiation in Scots pine roots. Plant Physiology., v.127, p.887-898, 2001. 
SEHMER, L.; DIZENGREMEL, P. Contribution to subcellular localization of superoxide dismutase isoforms of spruce needles and oak leaves. Journal of Plant Physiology, v.53, n.5-6, p.545-551, 1998.

SEPPÄNEN, M.M.; CARDI, T.; HYÖKKI, M.B.; PEHU, E. Characterization and expression of cold-induced glutathione-S-transferase in freezing tolerant Solanum commersonii, sensitive S. tuberosum and their interspecific somatic hybrids. Plant Science, v.153, p.125-133, 2000.

SHAW, B.P. Effects of mercury and cadmium on the activities of antioxidative enzymes in the seedlings of Phaseolus aureus. Biologia Plantarum, v.37, n.4, p.587-596, 1995.

SHIMBO, S.; ZHANG, Z.W.; MOON, C.S. Correlation between urine and blood concentrations, and dietary intake of cadmium and lead among womem in the general population of Japan. Int Arch Occuo Environmental Health, v.73, n.3, p.163-170, 2000.

SINGHAL, R.K.; ANDERSON, M.E.; MEISTER, A. Glutathione, a first line of defence against cadmium toxicity. FASEB Journal, v.1, n.(), p.220-223, 1987.

SKADSEN, R.W.; SCHUZELEFERT, P.; HERBST, J.M. Molecular cloning, characterization and expression analysis of two catalase isozyme genes in barley. Plant Molecular Biology, v.29, n.5, p.1005-1014, 1995.

SKORZYNSKA-POLIT, E.; BASZYNSKI, T. Differences in sensitivity of the photosynthetic apparatus in Cd-stressed runner bean plants in relation to their age. Plant Science ,v. 128, p.11-21, 1997. 
SKORZYNSKA-POLIT, E.; DRAZKIEWICZ, M., KRUPA, Z. The activity of the antioxidative system in cadmium treated Arabidopsis thaliana. Biologia Plantarum, v.47, n 1, p.71-78, 2003.

SMIRNOFF, N. The Role of Active oxygen in the response of plants to water deficit and desication. New Phytologist, v.125, p.27-28, 1993.

SMITH, I.K.; VIERHELLER, T.L.; THORNE, C.A. Assay of glutathione reductase incrude tissue-homogenates, using 5.5' DITHIOBIS (2-nitrobenzoic acid). Annal Biochemistry, v.125, p.27-58, 1988.

SMITH, I.K.; KENDALL, A.C.; KEYS, A.J., TURNER, J.C.; LEA, P.J. The regulation of the biosynthesis of glutathione in leaves of barley. Plant Science, v.41, p.11-17, 1985.

SMITH, R.H.; BHASKARAN, S.; MILLER, F.R. Screening for drought Tolerance In Sorghum Using Cell-Culture. In Vitro Cellular \& Developmental Biology, v.21,n.10, p.541-545, 1985.

SOMASHEKARAIAH, B.V.; PADMAJA, K.; PRASAD, A.R.K. Phytotoxicity of cadmium ions on germinating seedlings of mung bean (Phaseolus vulgaris) involvment of lipide peroxides in chlorophyll degradation. Physiologia Plantarum, v.85, n.1, p.85-89, 1992.

STEVENS, R.; CREISSEN, G.; MULLINEAUX, P. Cloning and characterisation of a cytosolic glutathione reductase cDNA from pea (Pisum sativum L.) and its expression in response to stress. Plant Molecular Biology, v.35, p.641-654, 1997. 
SUNG HI, LIU LF, LUR HS, KAO CH Sucrose-starvation-induced changes in polyamine and abscisic-acid levels of suspension-cultured rice cells Botanical Bulletin Of Academia Sinica, v.36, p.47-5, 1995.

SUZUKI, S.; KOIZUMI, N.; SANO.; H. Screening of cadmium-responsive genes in Arabidopsis thaliana. Plant, Cell and Environment, v.24, p.1177-1188, 2001.

TORRES AM, PATTO MCV, SATOVIC Z, CUBERO JI New isozyme loci in faba bean (Vicia faba L.): Genetic analysis and mapping using trisomics Journal Of Heredity, v. 89, p. 271-275, 1998.

TSUJI, N.; HIRAYANAGI, N.; IWABE, O.; TAKASHI, N.; TAGAWA, M.; MIYAMOTO, S.; MIYASAKA H.; MIYAMOTO, K. Regulation of phytochelatin synthesis by zinc abd cadmium in marina geen alga, Dunaliella tertiolecta. Phythochemistry, v.62, p.433-459, 2003.

TUKENDORF, A.; SKORZYNSKAPOLIT, E.; BASZYNSKI, T. Homophytochelatin accumulation in Cd-treated runner bean plants is related to their growth stage. Plant Science, v.129, p.21-28, 1997.

TUTIC, M.; SCHIRMER, R.H.; WERNER, D. Cloning and sequencing of mammalian glutathione reductase cDNA. Europen Journal Biochemistry, v.188, p.523, 1990.

USHA-KESHAN; MUKHERJI, S. Phytotoxic effect of cadmium as foliar spray on mungbean plant,. Indian Journal of toxicology, v.4, p.15-22, 1997. 
VAN CAMP, W.; HEROUART, D.; WILLEKENS, H.; TAKAHASHI, H.; SAITO, K.; VANMONTAGU, M.; INZE, D. Tissue-Specific activity of two manganese superoxide dismutase promoters in transgenic tobacco. Plant Physiology, v.112, n.2, p.525-535, 1996.

VATAMANIUK, O.K.; MARI, S.; LU, Y-P.; REA, P.A. Mechanism of heavy metal ion activation of phytochelatin (PC) synthase: blocked thiols are sufficient for PC synthase-catalyzed transpeptidation of glutathione and related thiol peptides. Jounal. Biological Chemistry, v.275, p. 31451-31459, 2000.

VITORELLO, V.A.; HAUG, A. Short-term aluminum uptake by tobacco cells: Growth dependence and evidence for internalization in a discrete peripheral region. Physiologia Plantarum, v.97, p.536-544, 1996.

VITORIA, A.P.; LEA, P.J.; AZEVEDO, R.A. Antioxidant enzymes responses to cadmium in radish tissues. Phytochemistry, v.57, p.701-710, 2001.

VOET, D.; VOET, J.G. Biochemistry, 2ª ed. New York: Wiley, 1995. 1361p.

VÖLLEGI-LANGE, R.; WAGNER, G.J. Relationship between cadmium, glutathione and cadmium-binding peptides (phytochelatins) in leaves of intact tobacco seedlings. Plant Science, v.114,p.11-18, 1996.

VRANOVÁ, E.; INZÉ, D.; BREUSEGEM, F.V. Signail transduction during oxidative stress. Journal of Experimental Botany, v.53, n.372, p.1227-1236, 2002.

WAGNER, G.J. Accumutation of cadmium in crop plants and its consequences to human health. Advances in Agronomy, v.51, p.173-212, 1993. 
WILLEKENS, H.; CHAMNONGPOL, S.; DAVEY, M.; SCHRAUDNER, M.; LANGEBAERTELS, C.; VAN MONTAGU, M.; INZÉ, D.; VAN CAMP, W. Catalase is a sink for $\mathrm{H}_{2} \mathrm{O}_{2}$ and is indispensable for stress defense in $\mathrm{C} 3$ plants. EMBO Journal, v.16, n.16, p.4806-4816, 1997.

WILLEKENS, H.; INZÉ, D.; VAN MONTAGU, M.; VAN CAMP, W. Catalases in plants. Molecular Breeding, v.1,p.207-228, 1995.

WINGSLE, G.; GARDESTRÖM, P.; HÄLLGREN, J.; KARPINSKI, S. Isolation, purification, and subcellular localization of isozymes of superoxide dismutase from scots pine (Pinus sylvestris L.) needles. Plant Physiology., v.95, p.21-28, 1991.

XIANG, C.B.; OLIVER, D.J. Glutathione metabolic genes cordinately respond to heavy metals and jasmonic acid in Arabidopsis. Plant Cell, v.10, n.9, p.1539-1550, 1998.

XU, Y.J.; Vanhuystee, R.B. Effect of Calcium, Its Inhibitors, and Heavy-Metals On the Growth-Cycle of Peanut Cell Aggregates. Plant Cell Tissue and Organ Culture, v.32, p.319-328, 1993.

YAMAMOTO, Y.; MATSUMOTO, K.; RIKIISHI, S.; HACHIYA, A.; YAMAGUCHI, Y.; MATSUMOTO, H. Aluminum tolerance acquired during phosphate starvation in cultured tobacco cells. Plant Physiology., v.112, p.217-227, 1996.

YANG, S.H.; BERBERICH, T.; SANO. H.; KUSANO, T. Specific association of transcripts of tbzF and tbz17, tobacco genes encoding basic region leucine-zipper type transcriptional activators, with guard cells of senescing leaves and/or flowers. Plant Physiology., v.127, p.23-32, 2001. 
ZHU, Y.L.; PILON-SMITS, E.A.H.; JOUANIN, L.; TERRY, N. Overexpression of glutathione synthetase in Indian Mustard enhances cadmium accumulation and tolerance oxygen. Plant Physiology, v.119, p73-79, 1999. 